\title{
Montana Gray Wolf Conservation and Management 2005 Annual Report
}

A cooperative effort by Montana Fish, Wildlife \& Parks, USDA Wildlife Services, Glacier National Park, Yellowstone National Park, and The Confederated Salish and Kootenai Tribes

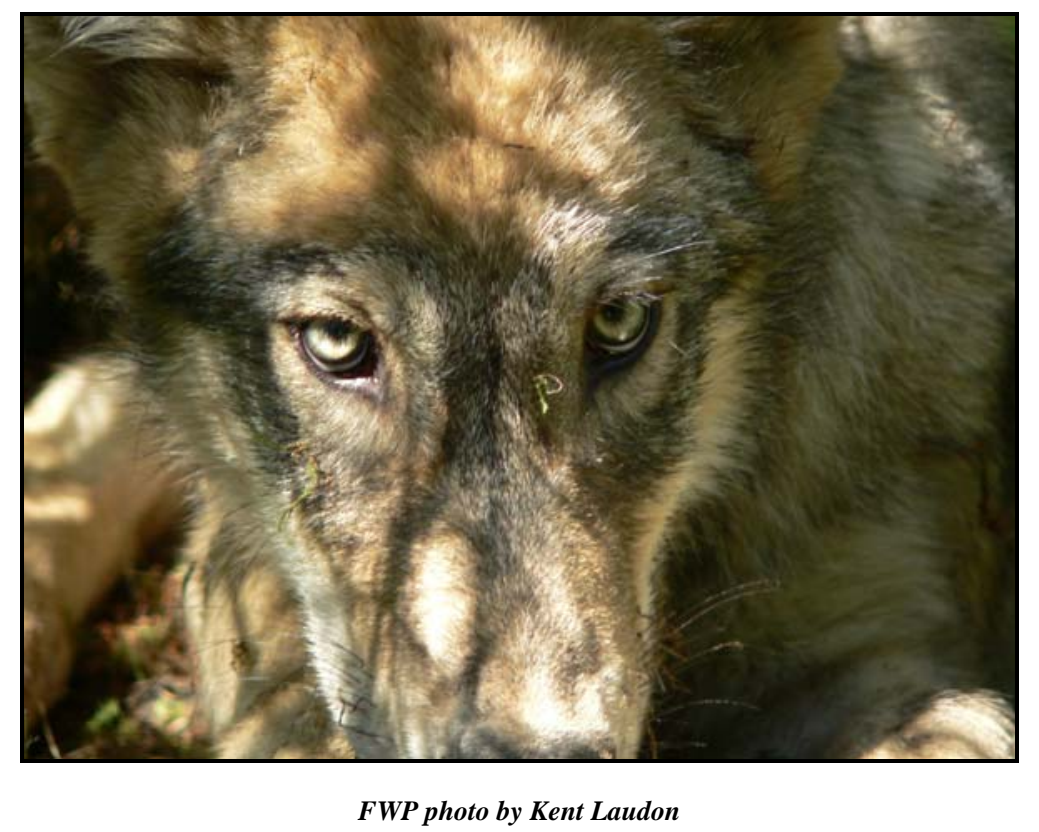

This report presents information on the status, distribution, and management of wolves in the State of Montana, from January 1, 2005 to December 31, 2005.

It is also available at: $\underline{w w w . f w p . m t . g o v / w i l d t h i n g s / w o l f ~}$

This report may be copied in its original form and distributed as needed.

Suggested Citation: Sime, Carolyn A., V. Asher, L. Bradley, K. Laudon, M. Ross, J. Trapp, and L. Handegard. 2006. Montana gray wolf conservation and management 2005 annual report. Montana Fish, Wildlife \& Parks. Helena, Montana. 95pp. 


\section{TABLE OF CONTENTS}

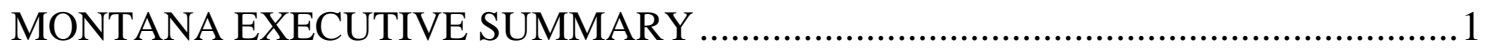

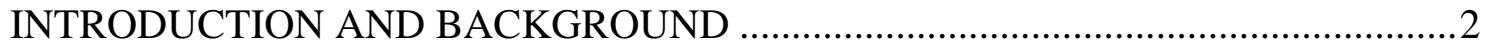

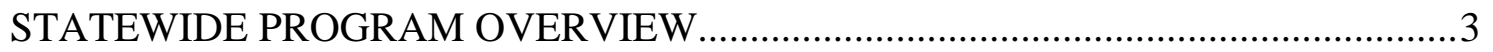

Overview of Wolf Ecology in Montana........................................................ 4

Population Estimation and Monitoring Methods............................................... 5

Montana Statewide Wolf Population and Distribution...................................... 7

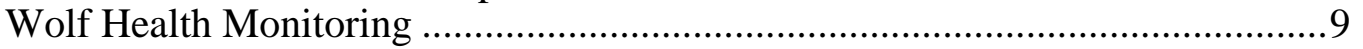

Wolf - Ungulate Relationships.................................................................. 11

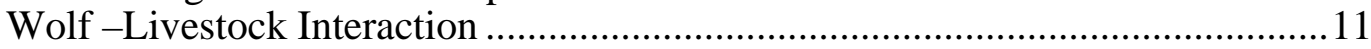

Depredation Incidents .................................................................................13

Defenders of Wildlife: Bailey Wildlife Foundation Wolf Compensation Trust..13

Development of a Montana-based Program .........................................................14

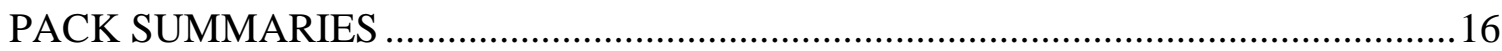

Northwest Montana Endangered Area..........................................................16

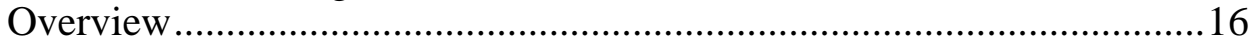

Verified Packs ...............................................................................17

Miscellaneous / Lone Individuals ........................................................224

Suspected Packs ................................................................................224

Other Miscellaneous Information ......................................................224

Southern Montana Experimental Area................................................................25

Montana Portion of the Greater Yellowstone Experimental Area.............25

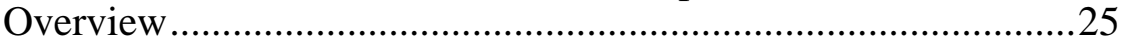

Verified Packs .............................................................................26

Miscellaneous / Lone Individuals ..............................................33

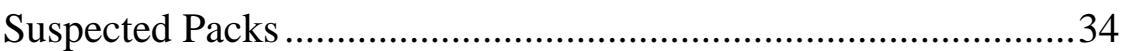

Other Miscellaneous Information ..............................................34

Montana Portion of the Central Idaho Experimental ...............................35

Overview ........................................................................ 35

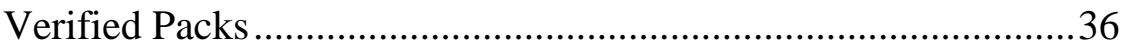

Miscellaneous / Lone Individuals ................................................4 41

Suspected Packs ....................................................................4 41

Other Miscellaneous Information ...........................................44

OUTREACH AND EDUCATION........................................................................4

RESEARCH AND OTHER FIELD STUDIES ...................................................43

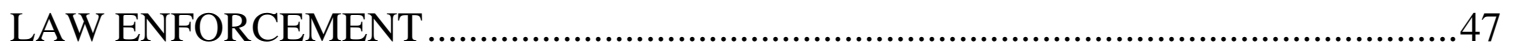

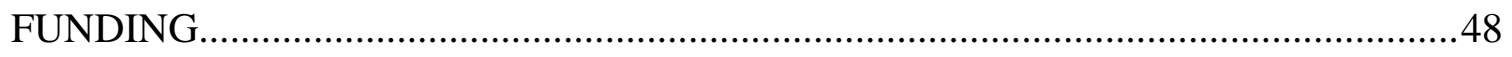

PERSONNEL AND ACKNOWLEDGEMENTS ..................................................... 48

NORTHERN ROCKY MOUNTAIN WOLF BIBLIOGRAPHY: 1999-2005 ...............51 


\section{TABLE OF CONTENTS, continued}

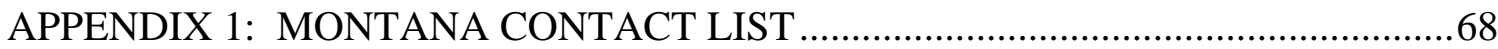

APPENDIX 2: CHRONOLOGY OF THE GRAY WOLF IN MONTANA …................70

APPENDIX 3: NORTHERN ROCKIES WOLF PACK TABLES..................................74

Table 1a. Northwest Montana wolf recovery area: wolf packs and population data 2005.................................................................. 75

Table 1b. Montana outside of NWMT recovery area (and statewide totals): wolf packs and population data 2005................76

Table 2. Wyoming wolf packs and population data 2005, and totals for Greater Yellowstone recovery area. ................................78

Table 3. Idaho wolf packs and population data 2005, and totals for Central Idaho recovery area. ....................................................79

Table 4a. $\quad$ Northern Rocky Mountains minimum fall wolf population and breeding pairs 1979-2005, by recovery

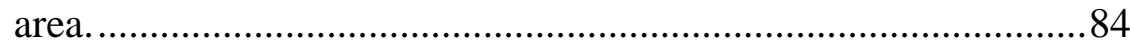

Table 4b. Northern Rocky Mountains minimum fall wolf population and breeding pairs 1979-2005, by state. ....................... 85

Table 5a. Northern Rocky Mountain states: confirmed wolf depredation and wolf management (by recovery area), 1987-2005.

Table 5b. Northern Rocky Mountain states: confirmed wolf depredation and wolf management (by state), 19872005

APPENDIX 4: NORTHERN ROCKIES WOLF PACK DISTRIBUTION MAPS .........89

Figure 1. Central Idaho, Northwest Montana and Greater

Yellowstone wolf recovery areas (Key: Tables 1 - 3). ..................90

Figure 2. Northwest Montana wolf recovery area (Key: Table 1a) ……....................................................................................91

Figure 3. Greater Yellowstone Wolf recovery area (Key: Tables

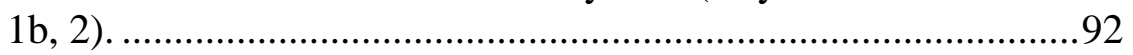

Figure 4. Central Idaho Wolf recovery area (Key: Tables 1b, 3)..................93

APPENDIX 5: NORTHERN ROCKIES WOLF POPULATION GRAPHS ...................94

Figure 5. Northern Rocky Mountain wolf population trends 1979-2005, by recovery area...... .95

Figure 6. Northern Rocky Mountain wolf population trends 1979-2005, by state. 


\section{LIST OF FIGURES}

Figure 1. Northern Rockies gray wolf recovery area comprised of the states of Montana, Idaho, and Wyoming. ……….....................................................

Figure 2. Map of the interim federal wolf management areas showing the endangered area where the 1999 Interim Wolf Control Plan applies and the experimental area where the 2005 10(j) regulations apply. 4

Figure 3. Minimum estimated number of wolves in the State of Montana, $1979-2005$.

Figure 4. Verified wolf pack distribution in the State of Montana, as of December 31, 2005.

Figure 5. Confirmed cattle and sheep depredation and the number of wolves lethally controlled in the State of Montana based on investigations by USDA Wildlife Services, 1995-2005.

Figure 6. Compensation payments by Defenders of Wildlife in Montana through September, 2005. Source:

http://www.defenders.org/wolfcomp.html. 


\section{MONTANA EXECUTIVE SUMMARY}

Wolf recovery in Montana began in the early 1980’s. Gray wolves increased in number and expanded their distribution in Montana because of natural emigration from Canada and a successful federal effort that reintroduced wolves into Yellowstone National Park (YNP) and the wilderness areas of central Idaho. The U.S. Fish and Wildlife Service (USFWS) approved the Montana Gray Wolf Conservation and Management Plan in early 2004, but delisting in the northern Rockies (NRM) was delayed. When federal funding became available later in 2004, Montana Fish, Wildlife \& Parks (MFWP) began managing wolves in northwestern Montana under a cooperative agreement with USFWS. In 2005, Montana expanded its responsibility for wolf conservation and management statewide under a new cooperative agreement. The agreement allows Montana to implement its federally-approved state plan to the extent possible and within the guidelines of federal regulations.

Using federal funds, MFWP monitors the wolf population, directs problem wolf control and take under certain circumstances, coordinates and authorizes research, and leads wolf information and education programs. MFWP wolf management specialists were hired in 2004 and are based throughout western and central Montana. A program coordinator is based in Helena.

The Montana wolf population increased from 2004 to 2005. The increase is due to a modest increase in actual wolf numbers and the increased monitoring efforts that led to verification of packs that actually existed in 2004 but were not counted in the 2004 estimate. A total of 46 verified packs of 2 or more wolves yielded a minimum estimate of 256 wolves in Montana. Nineteen packs qualified as a breeding pair according to the federal recovery definition. Across the southern Montana experimental area (Central Idaho and Greater Yellowstone areas combined), there were 27 packs, 9 of which met the breeding pair criteria. Across northwest Montana, there were 19 packs, 10 of which met the breeding pair criteria.

Mange was documented in several packs in the Greater Yellowstone area. That is believed to account, in part, for the poor pup survival in 2005. Additionally, most live wolves from which Montana personnel obtained a bloods sample demonstrated exposure to several canine viral diseases but these animals survived the exposure. It is not clear to what extent these diseases contributed to poor pup survival. Two other external parasites were also documented.

Montana Wildlife Services (WS) confirmed 23 cattle, 33 sheep, 1 dog and 2 horses were killed by wolves in calendar year 2005. Additional losses most certainly occurred, but could not be confirmed. Most depredations occurred on private property. Thirty five wolves were killed to reduce the potential for prevent further depredations, 7 of which were killed by private citizens under the new 2005 10(j) regulations in the experimental area of southern Montana.

Wolves in Montana prey primarily on elk, deer, and moose. Numerous research projects are investigating wolf-ungulate relationships. Montana Fish, Wildlife \& Parks recently compiled research results of wolf-ungulate interactions in southwest Montana. This report and other information about wolves and the Montana program are available at www.fwp.mt.gov/wildthings/wolf. 


\section{INTRODUCTION AND BACKGROUND}

Wolf recovery in Montana began in the early 1980’s. Gray wolves increased in number and expanded their distribution in Montana because of natural emigration from Canada and a successful federal effort that reintroduced wolves into Yellowstone National Park (YNP) and the wilderness areas of central Idaho. Montana contains portions of all 3 federal recovery areas: the Northwest Montana Endangered Area (NWMT), the Central Idaho Experimental Area (CID), and the Greater Yellowstone Experimental Area (GYA) (Figure 1).

The biological requirements for wolf recovery in the northern Rocky Mountains of Montana, Idaho, and Wyoming were met in December 2002. Before the U.S. Fish and Wildlife Service (USFWS) can propose to delist gray wolves, federal managers must be confident that a secure, viable population of gray wolves will persist if protections of the Endangered Species Act (ESA) were removed. To provide that assurance, the states of Montana, Idaho, and Wyoming developed wolf conservation and management plans and adopted other regulatory mechanisms in state law.

In late 2003, all 3 states submitted wolf management plans to USFWS for review. Based on the USFWS's independent review of the state management plans and state law, analysis of the comments of independent peer reviewers and the states' responses to those reviews, USFWS approved the Montana and Idaho management plans as being adequate to assure maintenance of their state's share of the recovered tri-state wolf population. Wyoming's plan, however, was not approved. USFWS will not propose delisting until the Wyoming plan and associated state laws can be approved.

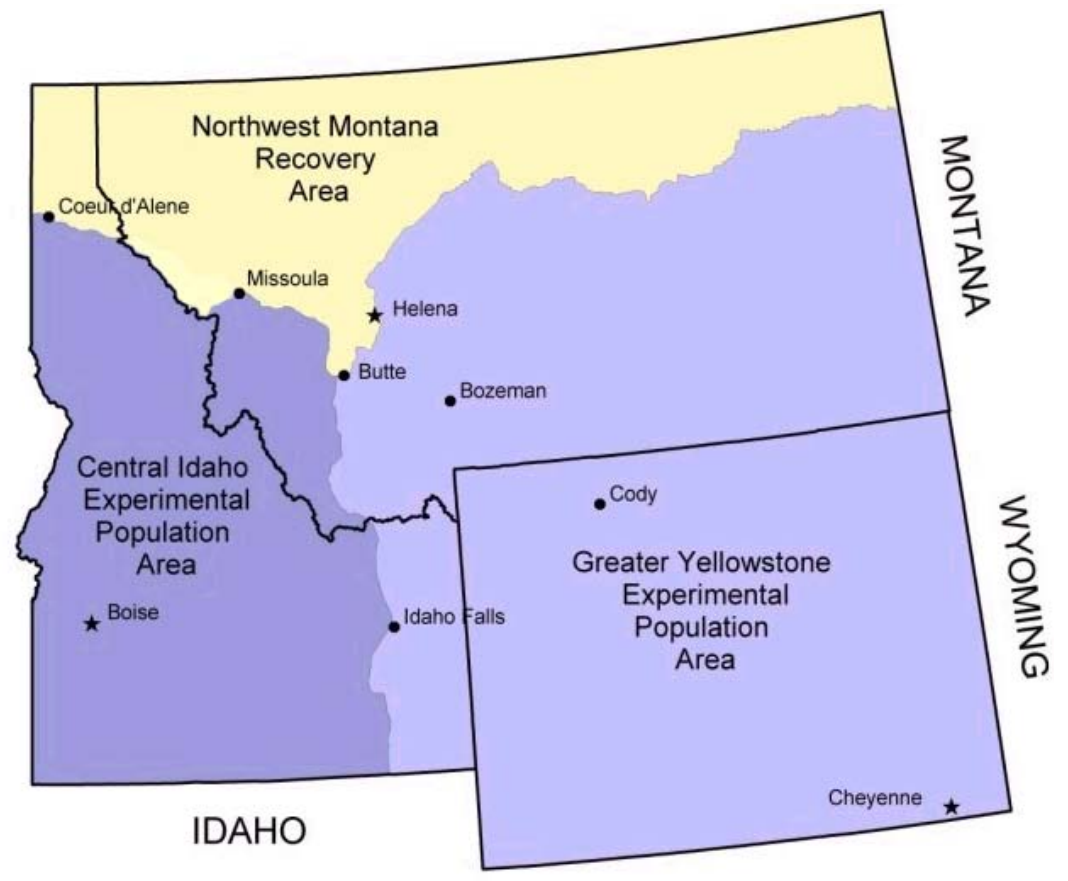

Figure 1. Northern Rockies gray wolf recovery area comprised of the states of Montana, Idaho, and Wyoming 
After amending its Record of Decision to comply with the Montana Environmental Policy Act, MFWP increased its role in day-to-day wolf recovery and management in northwest Montana under an interim interagency cooperative agreement even though wolves remain protected under the federal Endangered Species Act. USFWS provided direct funding.

In 2005, MFWP expanded its responsibility for wolf conservation and management statewide. Additional federal funding became available through Congress, beginning in federal fiscal year 2004. A new MFWP-USFWS interagency cooperative agreement was finalized in June 2005. With a clear agreement in place and federal funding to support the work, MFWP became the lead agency for wolf conservation and management statewide in June 2005, though its role and participation gradually increased from spring 2004 to June 2005. The agreement is effective through June 2010, or until the wolf population in Montana is removed from the federal list of threatened or endangered species, or until amended by either party.

The cooperative agreement allows Montana to implement its approved state plan to the extent possible and within the guidelines of federal regulations. The cooperative agreement authorizes Montana to conduct traditional wolf management such as population monitoring, direct problem wolf control, take wolves under certain circumstances, coordinate and authorize research, and coordinate and lead wolf information and education programs. Montana is committed to maintaining the recovered status of its share of the NRM wolf population.

This annual report presents information on the status, distribution, and management of wolves in the State of Montana from January 1 to December 31, 2005.

\section{STATEWIDE PROGRAM OVERVIEW}

The Montana Wolf Conservation and Management Plan is based on the work of a citizen's advisory council. Completed in 2003, the foundations of the plan are to recognize gray wolves as a native species and a part of Montana's wildlife heritage, to approach wolf management similar to other wildlife species such as mountain lions, to manage adaptively, and to address and resolve conflicts.

However, because wolves are still listed, some elements of Montana's plan cannot be implemented. The legal classification and federal regulations place wolves into 2 separate categories in Montana - endangered in northern Montana and experimental non-essential across southern Montana (Figure 2). Wolf-livestock conflicts are addressed and resolved using a combination of the statewide adaptive management triggers identified in the Montana plan and the federal regulations. In northwest Montana, the 1999 Interim Control Plan provides less flexibility to agencies and livestock owners. In contrast, more flexibility is provided through the revised 10(j) regulations (finalized in February 2005).

In the early stages of implementation, a core team of experienced individuals led wolf monitoring efforts and worked directly with private landowners. MFWP's wolf team also worked closely with and increasingly involved other MFWP personnel in program activities. As time goes by, Montana wolf conservation and management will transition to a more fully 
integrated program, led and implemented at the MFWP Regional level. USDA Wildlife Services (WS) investigates injured and dead livestock, and MFWP works closely with them to resolve conflicts.

\section{Overview of Wolf Ecology in Montana}

Wolves were distributed primarily in the NRM region of western Montana east to the Beartooth face near Red Lodge. Montana wolf pack territories average around 200 square miles in size but can be 300 square miles or larger. Montana packs include a combination of public and private lands. The average pack territory in Montana is comprised of 30\% private land. Most Montana packs do not live strictly in back country wilderness area. Of the 46 packs in Montana, only 2 reside most of the year in wilderness areas. Many others live in areas of remote public lands. But the majority live in areas where mountainous terrain, intermountain valleys, and public / private lands come together.

Dispersal distances in the northern Rockies average about 60 miles, but dispersals over 500 linear miles have been documented. A 500-mile radius from any wolf pack in YNP, Glacier National Park (GNP), or any pack in western Montana would plausibly reach all the way to Montana's eastern border. Montanans should be aware that wolves are established well enough in the northern Rockies now that a wolf could appear where none has been seen for decades. Wolves are capable of covering long distances in relatively short periods of time and often travel separately or in smaller groups. The travel ability of wolves, combined with the fact that packs split, with sub-groups traveling separately, can give an impression that there are more wolf packs and territories than is actually the case. Pack monitoring efforts, especially when combined with public / agency wolf reports, eventually leads to a conclusion about how many packs exist.

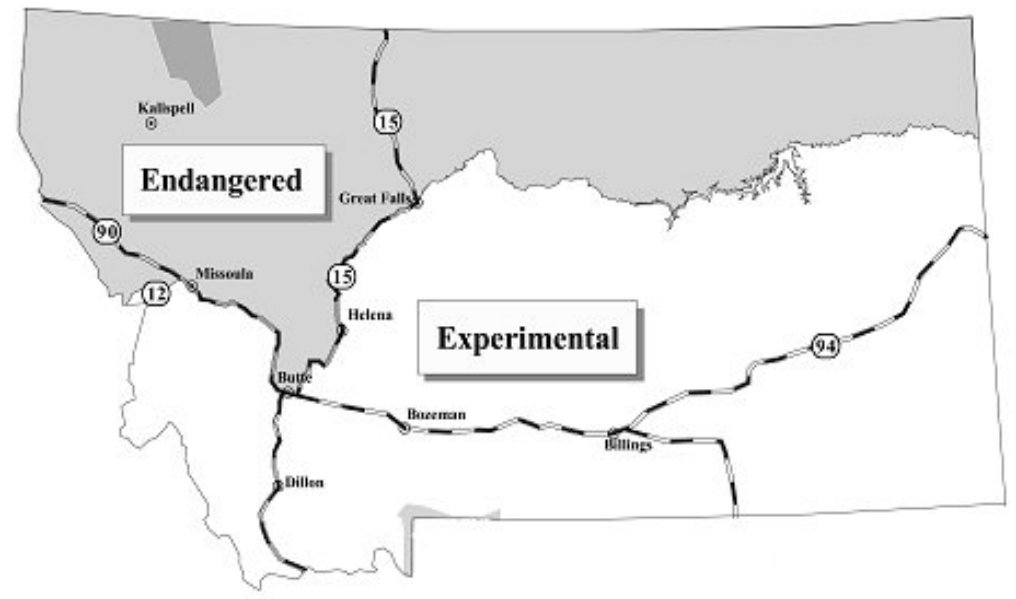

Figure 2. Map of the interim federal wolf management areas showing the endangered area where the 1999 Interim Wolf Control Plan applies and the experimental area where the 10(j) regulations apply. The central Idaho and Greater Yellowstone experimental areas are shown as one since the approved status of Montana's state wolf plan allows the special 10(j) regulations to apply equally in each area. 
Wolf packs are family groups that consist of a breeding pair and their offspring of the current year and/or previous years and occasionally unrelated wolves. Offspring usually disperse from the natal pack at 1, 2 or 3 years of age. From, 1995 to 2005, the average pack in Montana was approximately 6 animals. It is less than the average pack size in the states of Idaho and Wyoming. Average pack sizes in the experimental area across southern Montana are slightly larger than in the endangered area of northwest Montana, but still approximately 6 animals.

Montana wolves can be black, gray, or nearly white. Wild wolves are sometimes mistaken for coyotes or domestic dogs. But a wolf's large size, long legs, narrow chest, large feet, and wide / blocky head and snout distinguish it from the other canid species. Adult male wolves average about 100 pounds, but can weigh as much as 130 pounds. Females weigh slightly less.

\section{Population Estimation and Monitoring Methods}

The statewide Montana wolf population was estimated on a calendar year basis (January to December). A mid-year estimate is completed and made available, usually in September. It was based on preliminary denning and litter information for packs that carried over from the previous calendar year and any "new" packs that were verified by mid-year. A year-end estimate was made on December 31, based upon the best available information.

There can be considerable changes between September and December estimates. Some packs may appear in the mid-year estimate but drop out between the September and the December estimate if it was not verified during the second half of the year. Some "new" packs were verified for the first time between the mid-year and year-end estimates. The mid-year estimate and the final year-end estimate were both considered minimum counts because of the significant logistical challenges associated with monitoring a wide-ranging species with large home ranges. It was not possible to count every wolf in Montana, but MFWP did use all available information that could be verified.

Wolf monitoring is conducted using a variety of tools and techniques in combination, as is the case for other wildlife species. Common wolf monitoring techniques include: radio telemetry, howling and track surveys, reports from the public and other natural resource agency professionals, and reports from private landowners. MFWP made a concerted effort in 2005 to invite the public to help monitor wolves in Montana by sharing information about wolves or wolf sign they observed while afield. The MFWP website now offers a way for the public to report their information electronically (see www.fwp.mt.gov/wildthings/wolf). Public reports were a tremendous help in prioritizing MFWP's field efforts. A wolf pack must be verified by agency personnel to be included in the final statewide population estimate.

A typical sequence is as follows. MFWP and other agency cooperators receive a report of a wolf observation, wolf sign, or injured/dead livestock from the public or an agency colleague.

Because it is very difficult to gauge the reliability and validity of the report and it is even more difficult to verify given how much wolves travel and environmental conditions which obliterate tracks or degrade scats, these reports are logged into a database with as much spatially explicit information as is provided. Reports of lone animals or wolf sign must eventually be linked to other reports to build a pattern or cluster, which in turn helps direct and prioritize field efforts. If 
MFWP receives reports of multiple individuals (group of wolves or multiple sets of tracks), pair bonding and pack territory establishment are highly likely. These eventually can form a pattern as well.

MFWP has and will continue to use volunteers who systematically search areas of current wolf reports, areas of past wolf activity, or noted "gaps" in wolf activity despite adequate prey base. MFWP personnel also conduct systematic searches. Track logs are taken during these "routes" and waypoints recorded when wolf sign is found.

The next step occurs when patterns and field reconnaissance yield enough information to validate wolves were in the area. A decision was made about whether to try and capture a wolf or not. Many factors were considered when prioritizing field efforts across the state. Not all packs needed to have radio collars, while others should have had one or more collars.

Regardless, radio telemetry has been the standard technique with other protocols developed and validated based on a sample of collared packs. Project staff spent much of their time throughout the year conducting ground-based trapping operations and helicopter darting in winter. Reliable information about specific packs and the overall statewide population was essential to implement the approved state plan and adhere to the federal regulations.

If a pack was trapped and a radio collar is deployed, MFWP flew 1 to 2 times per month to locate the collared animal. In addition, wolves were ground tracked to determine where they localized throughout the year and the number of wolves traveling together. Den sites and rendezvous sites were visited to determine if reproduction had taken place. Additional information may be collected, such as ungulates killed, identification of private lands used by wolves, identification of public land grazing allotments where conflicts could occur, or common travel patterns.

At the end of the year, MFWP compiled information gathered through field surveys, telemetry, and public reporting. This results in a greater understanding of wolf pack distribution, individual pack sizes, pelage colors, mortality, pup production, home range sizes and patterns of use within the territory, dispersal events, and disease. The information also guided decision-making when livestock depredations were confirmed. MFWP also gained insight into the large area wolves inhabit, the dynamics of pack size, and territory shifts within and between years.

MFWP estimated the number of individual wolves (adults and pups of the year) in each pack having a radio-collared member. Reliable estimates were made for packs without collars, based on public and other agency reports. The number of wolves in radio-collared packs was added to the number of wolves in verified, uncollared packs, resulting in the minimum statewide population total. If lone dispersing animals were accounted for reliably, they are also included.

Through it's monitoring program, MFWP was required to also tally and report the number of "breeding pairs" according the federal recovery definition of "an adult male and a female wolf that have produced at least 2 pups that survived until December 31." Montana is required to maintain at least 10 breeding pairs as an absolute minimum. Packs of 2 or more wolves that met the recovery definition are considered "breeding pairs" and noted as such in the summary tables. Not all packs in Montana satisfy the breeding pair criteria. This can be caused by the loss of 1 or 
both adults because of mortality or dispersal, lack of denning activity, or the loss of pups to the extent the surviving litter consists of 1 pup.

The total number of packs was determined by counting the number of packs with 2 or more individual animals that existed on the Montana landscape on December 31. If a pack was removed because of livestock conflicts or otherwise did not exist at the end of the calendar year (e.g. disease, natural/illegal mortality or dispersal), it was not included in the year-end total or displayed on the Montana wolf pack distribution map for that calendar year.

Such comprehensive information allowed Montana to document the maintenance of its share of the recovered NRM tri-state population and that the Montana population was secure in 2005.

The Montana wolf population was more intensively monitored on a consistent, year-round basis than any other wildlife species in the state.

In 2005, several wolf pack territories straddled administrative boundaries. Examples of transboundary packs included: the former Kootenai pack (U.S. / Canadian border), Chief Joseph (YNP / Montana state border), and Fish Creek (Montana / Idaho border). NRM wolf program cooperators have agreed that packs will be tallied in the population in the administrative area where the den site was located. If the den site was not known with certainty, amount of time, percent of territory, or the number of wolf reports were the next criteria considered for determining pack residency. One of the project partners generally had the lead for wolf monitoring, but the information was shared equally. This assures that all packs were accounted for, but none were double-counted in population estimates. Transboundary packs were included in the table (Tables 1, 2, 3) for the administrative region in which the animals were counted.

\section{Montana Statewide Wolf Population and Distribution}

The Montana wolf population is very dynamic. Some packs do not persist from year to year for a variety of reasons. About the same number of new packs formed or were verified for the first time in 2005 as the number of 2004 packs that no longer existed at the end of 2005. The loss of packs in the Montana population could be due to a variety of factors, including mortalities and poor pup production due to parasites and disease, and lethal control to address conflicts with livestock. In some cases, some packs that were either verified or suspected in 2004 no longer existed by the end of 2005.

The Montana wolf population increased from 2004 to 2005. The increase was due to a variety of factors. Some of the increase was attributed to a real increase in wolf numbers in 2005, since many new packs formed and produced pups in 2005. Of greater significance however, was MFWP's increased efforts to monitor wolves compared to previous years. MFWP's field staff monitored the population year round, using a variety of techniques. In addition, MFWP made a concerted effort to gather wolf reports from the public and other agency professionals. Many of the "new" packs verified in 2005 were likely present in 2004 but were not confirmed and included in the 2004 population estimate. Additionally, several transboundary packs were tallied in the Montana population for the first time. 
There were a total of 46 packs ( 2 or more wolves), resulting in an estimated minimum of 256 wolves in Montana at the end of 2005 (Figure 3). The average number of wolves per pack increased from about 4.5 wolves per pack in 2004 to 5.5 wolves per pack in 2005. There were 19 breeding pairs statewide. In the NWMT endangered area, there were a total of 19 packs, 10 of which met the breeding pair criteria. There was an estimated minimum of 126 wolves in the endangered area at the end of 2005. This was significantly greater than the 2004 estimates, due in part to the formation of several new packs, increased monitoring efforts that verified packs formed, but not tallied in 2004, strong pup survival, and the inclusion of a few transboundary packs in the Montana population estimate.

In the experimental area across southern Montana, there were 27 packs, 9 of which met the breeding pair criteria. In the Montana portion of the GYA, there was an estimated minimum of 66 wolves in 16 packs, and 3 of the packs met the breeding pair criteria. Overall pup production and survival was down in 2005. In the Montana portion of CID, there was an estimated minimum of 64 wolves in 11 packs, and 6 of the packs met the breeding pair criteria. This was about the same number of wolves as estimated in 2004, but the number of packs and breeding pairs doubled. Overall across the southern Montana experimental area, minimum estimated wolf numbers and the number of breeding pairs was stable from 2004 to 2005, but the number of packs increased.

Of notable interest for western Montana was that wolf pack distribution expanded primarily within areas already expected to have wolves (Figure 4). The number of wolf packs in western Montana increased significantly from 2004 to 2005. This could be due to higher wolf dispersal into Montana from Idaho than from the GYA.

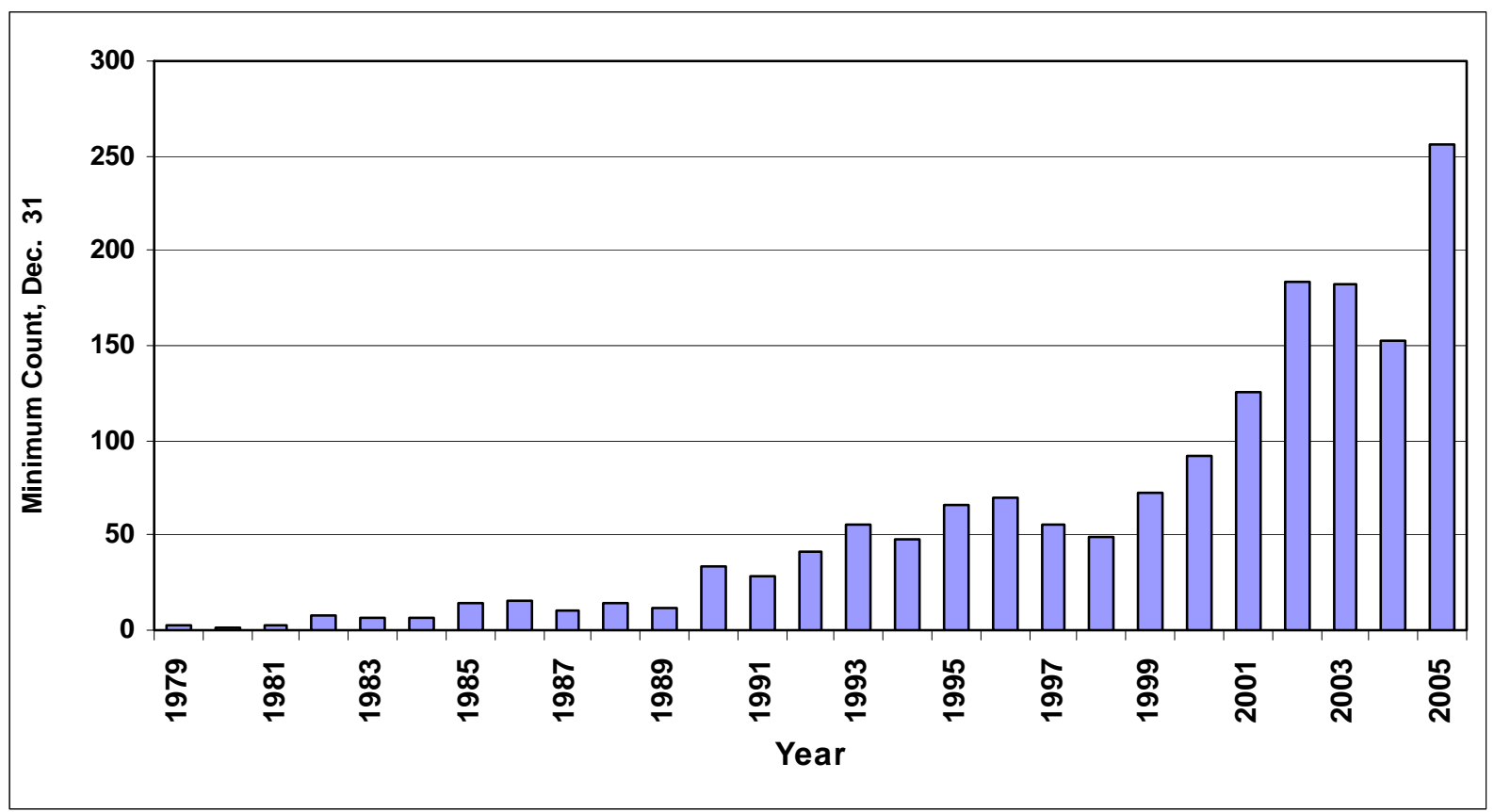

Figure 3. Minimum estimated number of wolves in the State of Montana, 1979-2005. 


\section{Wolf Health Monitoring}

MFWP's Wildlife Research Laboratory (Lab) in Bozeman played an important role in Montana's wolf monitoring program. In 2005, MFWP's wildlife veterinarian drafted a biomedical protocol that guided wolf capture, physical or chemical immobilization procedures, and animal care and handling procedures. Supplementary training was provided, and routine consultation assured adherence to the protocol. Additionally, lab personnel carried out routine wolf health and disease surveillance by collecting information from both live and dead wolves.

Blood samples collected by MFWP and WS from live-captured wolves were sent to the Lab. Blood was screened for exposure to various diseases, and some was archived in a DNA repository. Twenty-one blood samples were collected and submitted to the lab in 2005. Usable samples were forwarded for hematology, biochemistry, and serology screening. All of the hematology and biochemistry results were within normal limits expected for wolves. However, serology results indicated that most of those individuals had been exposed to some common canid viral and bacterial diseases: canine parvovirus, canine distemper, canine adenovirus, and leptospirosis. The presence of these antibodies in blood collected from live wolves indicated exposure at some time in the animal's life, but that it survived the exposure. While there has been much speculation about the cause of low pup counts in southwest Montana and inside YNP, clinical evidence to confirm the cause/s was very difficult to obtain.

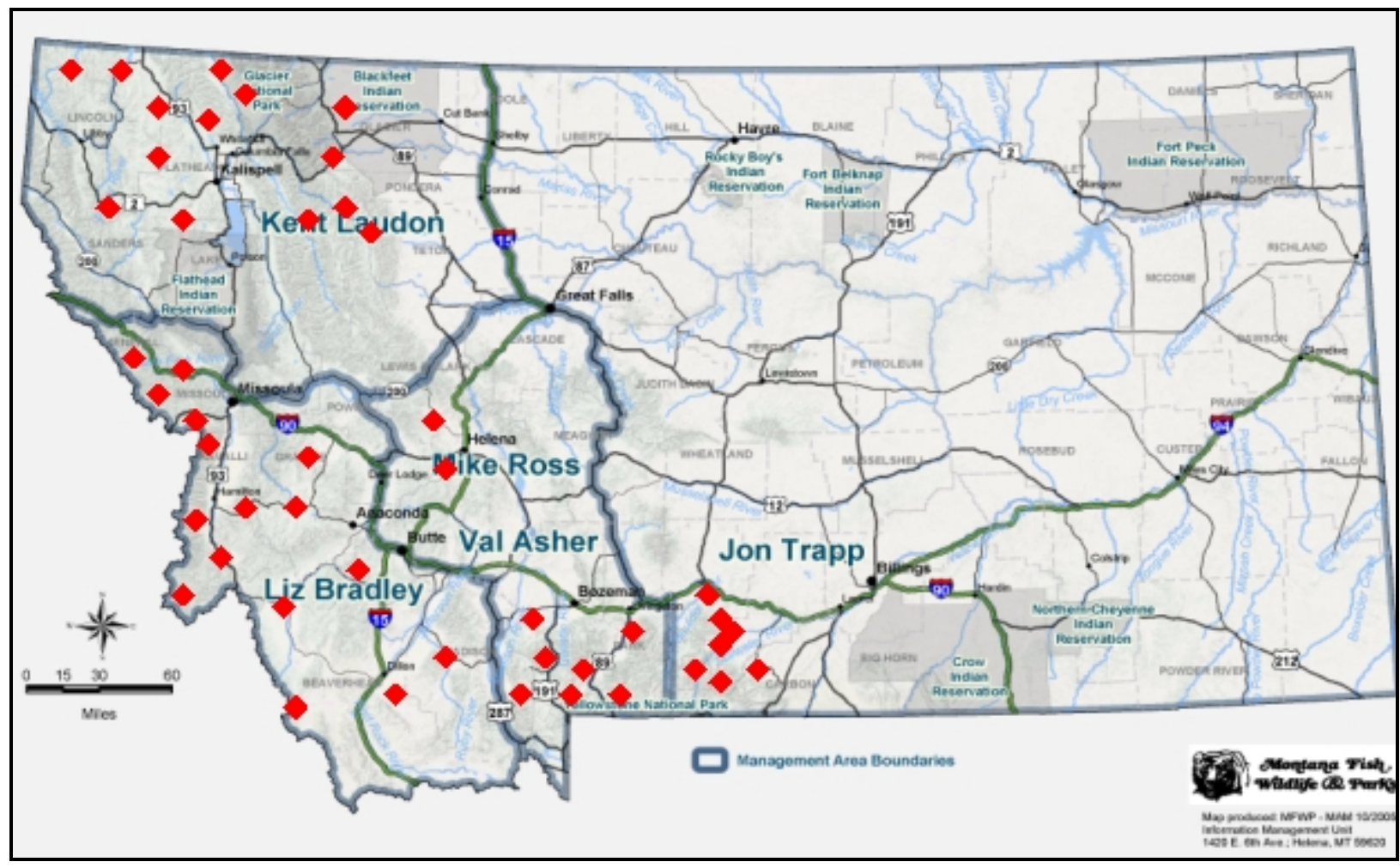

Figure 4. Verified wolf pack distribution in the State of Montana as of December 31, 2005. 
Additionally, MFWP developed a protocol that called for all dead wolves found in Montana to be submitted to the lab for necropsy examination. Unless special instructions were provided, a standard basic procedure was followed. Typical information collected includes cause of death, body weight, evidence of ectoparasites, etc. Various biological data were also collected. The first premolar, the skull, and a tissue sample were collected and stored. Salvageable hides were retained and processed for educational purposes. The veterinarian had discretion to complete a more in-depth necropsy if preliminary findings warranted additional examination. Abnormal or suspect tissues were submitted to the Montana State Diagnostic Laboratory (or occasionally elsewhere) for further evaluation. Lab personnel may also assist and consult during USFWS law enforcement investigations to determine cause of death and examine physical evidence.

In 2005, a total of 48 wolves (25 males, 10 females, 3 unknowns) were processed. The majority was killed in response to wolf-livestock conflicts. Cause of death could not be determined for 5 wolves. Five wolves were struck and killed by vehicles in 2005. Eight wolves were euthanized for various reasons, including spinal trauma and extremely poor health (e.g. mange).

Several packs in southwest Montana (Montana portion of the GYA) were documented with symptoms associated with Sarcoptic mange (Sarcoptes scabeii). Thus far, mange has been detected in wolf packs living primarily east of the continental divide. Mange is caused by an external mite that burrows into the wolf's skin causing, irritation, hair loss, lesions and scabs. In advanced cases, it can be fatal because of a chronically weakened immune system, secondary infections, or even hypothermia due to hair loss. The mite is spread by direct body contact with an infected animal or by contact with something that an infected animal contaminated. It was impossible to effectively treat infected wild, free-ranging wolves for logistical and environmental reasons.

Nine wolves out of the 48 total examined at the Lab in 2005 ( 19\%) exhibited chronic skin disease characterized by varying degrees of hair loss, scaling and crusting. One wolf died of starvation associated with mange. Mange affected the survival of individual wolves and may in fact affect population trends. The potential for mange to affect overall population trends in Montana is not known. Mange and the viral diseases mentioned previously may be have greater negative effects on pups since their immune systems are still developing.

In addition to mange, three more pathogens were identified in Montana in 2005. Biting dog lice (Tricodectes canis) was documented in Montana for the first time in 2005. Two wolves from the Battlefield pack were found to have a single louse parasite. These lice have been found on wolves in Alaska and Minnesota. Another second unusual pathogen was identified in a pup that was euthanized in southwest Montana. Muscular sarcocystosis (Sarcocytis sp.), which was considered a rare finding in canids, was confirmed. The clinical significance of this unusual finding is unknown. The third pathogen of interest was trichinosis (trichinella larvae found in skeletal muscle). It was also documented in this same pup, but it is somewhat common in predators. It is transmitted by the ingestion of infected muscle tissue from another host. Work in Alaska indicates that trichinella infection has no measurable impact on either individual wolves or the population. 


\section{Wolf - Ungulate Relationships}

In mountainous areas with harsh winter weather conditions, less productive vegetation, and multiple predator species including grizzly bears, wolf predation seemed to be more influential than in areas where livestock were present seasonally or year round. Outside national parks, Montana's wolves routinely encountered livestock. Lethal wolf control to resolve wolf-livestock conflicts seemed to decrease local wolf densities to a point where wolf predation did not appear to significantly affect elk populations (See Hamlin 2005).

Montana elk herds that inhabit YNP seasonally have declined, due in part to predation where local wolf densities (among other predator species) were high. In a few areas, MFWP curtailed hunter opportunity in 2004 and 2005. Yet in other areas where wolves and elk interact, elk numbers are stable or increasing. Two thirds of the hunting districts in southwest Montana (all of which support wolves) are currently offering the most liberal hunting opportunities seen in nearly 30 years as a management response to higher elk populations.

Research has shown that elk use habitat differently since wolves have returned. One study showed that when wolves were in the local area, elk spent less time in open areas and more time in forested areas. This seems to have affected individual hunters on individual days. Hunters may need to adjust their strategies.

MFWP biologists now consider wolf activity among the many factors potentially affecting big game populations and hunter success. MFWP earmarked money from the federally-funded wolf program to increase big game monitoring efforts to keep closer tabs on prey populations. This supplements existing data on ungulates populations. In 2005 and early 2006, additional surveys for moose were initiated in the North Fork Flathead River, in the White Sulphur Springs area, and south of Phillipsburg. Additional moose survey efforts will be directed at moose populations along the Beartooth face south of Billings and in southwest Montana. Additional elk and moose surveys will be conducted along the Montana-Idaho border, west of Missoula.

In addition, MFWP is actively involved in various research projects that are investigating predator-prey relations, population dynamics of black bears and mountain lions, large carnivore monitoring techniques, and wildlife diseases. See Hamlin (2005) on the MFWP website wolf pages under "Wolves - Big Game" for additional information on what MFWP has learned so far.

\section{Wolf - Livestock Interactions}

Montana wolves routinely encounter livestock on both public grazing allotments and private land. Wolves are opportunistic predators, most often seeking wild prey. However, some wolves "learn" to prey on livestock and teach this behavior to other wolves. Wolf depredations are very difficult to predict in space and time. Between 1987 and 2005, the vast majority of cattle (88\%) and sheep (91\%) wolf depredation incidents confirmed by WS occurred on private lands. The likelihood of detecting injured or dead livestock is probably higher on private lands where there was greater human presence than on remote public land grazing allotments. The magnitude of under-detection of loss on public allotments was not known. Nonetheless, most cattle 
depredations occurred in the spring or fall months while sheep depredations occurred more sporadically throughout the year.

WS investigated reports of injured or dead livestock or domestic dogs in Montana. Estimated on a federal fiscal year basis from 2002-2004, slightly more than half of investigations were verified as wolf-caused. The rest were not "confirmed" or "probable" wolf-related (i.e. injuries or death which could be due to a different predator species, poisonous plants, lightning, disease, etc). In the cases that were either classified as a "confirmed" or a "probable" wolf depredation, MFWP had to decide how to address the problem with WS's help and coordination with the livestock producer.

Because wolves are still listed under ESA, wolf-livestock conflicts were addressed using a combination of the approved state plan and federal regulations. Among other things, MFWP considered the number of breeding pairs statewide and in the respective interim management areas (endangered area or experimental area), where the incident occurred, and a pack's previous history with livestock when deciding what to do. MFWP and WS tried to connect the management response and the damage closely in space and time, targeting the offending animal/s. WS personnel carried out the lethal control work. MFWP strove to assure the security of the overall wolf population, while addressing depredation losses and control in an incremental fashion.

Both MFWP and WS also provided advice and technical information to individual livestock producers about proactive strategies that may decrease their risk of wolf depredations. Project personnel also worked collaboratively with interested private organizations and local-level community groups (e.g. watershed groups) to provide technical advice and to investigate nonlethal methods of deterring livestock conflicts.

Non-lethal deterrents were explored proactively to hopefully prevent wolf depredations and were considered after confirmed and probable wolf-caused losses. MFWP personnel collaborated with other wolf managers from around the world to discuss new ways to address conflicts and to exchange "experiences." MFWP and WS staff worked closely to share information throughout the year. This collaboration allowed for timely and well thought out decisions with respect to the application of both non-lethal and lethal tools when conflicts occurred.

While wolves remain listed under ESA, there are two different classifications and legal frameworks for addressing wolf-livestock conflicts (Figure 2). Wolves across northern Montana are classified as endangered, which offered both livestock producers and MFWP less flexibility. The 1999 Interim Control Plan ultimately guided decisions about lethal control. Citizens cannot harass or kill wolves on private lands, state leases, or federal lands. State and federal agency personnel were responsible for all harassment activity and lethal control of all wolves in the endangered area.

Wolves across southern Montana are classified as experimental, nonessential. Because Montana has a federally-approved management plan, additional flexibility became available to both MFWP and livestock producers in February 2005. Known as the 10(j) regulations, members of the public in the experimental area had the ability to non-injuriously harass wolves that were too 
close to livestock any time. If wolves were seen actively chasing or attacking livestock on private or federally permitted lands during the active permit, livestock owners, their immediate family members or employees could legally take the wolf. Physical evidence that demonstrated that an attack was imminent was required. All cases of harassment or lethal take had to be reported to MFWP within 24 hours. The 10(j) regulation was patterned after the Montana "defense of property" statutes that will take effect upon delisting allowing take "in the act" of attacking domestic livestock

\section{Depredation Incidents}

The majority of wolf-livestock interactions took place in the experimental area across southern Montana. Livestock densities (number of cattle and sheep per square mile) in south central Montana counties are some of the highest of any in Montana. Habitat, ungulate distribution, and landscape features placed wolves and livestock in closer proximity in space and time than other parts of the state.

Between 1987 and 2005, most confirmed cattle depredation events in Montana occurred in spring (March, April, May) when calves were small and most vulnerable. A smaller spike occurred in the fall (September and October), presumably as food demands of the pack increased and pups are traveling with the pack. In addition, wild ungulates were still well dispersed on summer range and young-of-the-year ungulates were more mobile. Most confirmed sheep depredation events in Montana occurred in July and October. Because of their smaller size relative to cattle or other classes of livestock, sheep can be vulnerable to wolf predation year round.

WS confirmed a total of 23 cattle, 33 sheep, 1 dog (several others were injured and survived), 1 colt and 1 horse killed by wolves in Montana in 2005 (Figure 5). Additional investigations were determined to be probable wolf depredations. Furthermore, some livestock producers reported "missing" livestock and suspected wolf predation. Other reported indirect losses include poor weight gain and aborted pregnancies. There is no doubt that there are undocumented losses. It is difficult to quantify direct and indirect economic losses in totality.

In the endangered area across northern Montana, 2 wolves were lethally controlled - one from a pack near Helena and one on the Blackfeet Reservation. Both conflicts involved cattle and were confirmed by WS. In the experimental area across southern Montana, 33 wolves were killed in lethal control actions. Private citizens killed 7 of the 33 (21\%) under the $10(\mathrm{j})$ regulations in 2005. All incidents occurred on private property, and most incidents involved cattle. Each incident was investigated by USFWS Law Enforcement Agents and was determined to be within the parameters established by the 10(j) regulation.

\section{Defenders of Wildlife: Bailey Wildlife Foundation Wolf Compensation Trust} (source: http://www.defenders.org/wolfcomp.html)

In 1987, Defenders of Wildlife created at $\$ 100,000$ fund to compensate livestock producers in the NRM for verified livestock losses due to wolves. The goal was to help reduce wolf-related 
economic losses as a result of wolf recovery. The trust expanded to $\$ 200,000$ in 1999 . In the fall of 2000, the wolf and grizzly bear compensation fund and trusts were renamed the Bailey Wildlife Foundation Wolf Compensation Trust. This is the only compensation program currently available in Montana.

The program pays for $100 \%$ of the fall market value for a WS-confirmed wolf-caused loss up to \$2000 per animal and 50\% of the market value for probable losses. Livestock losses covered include: sheep, cattle, horses, mules, goats, llamas, donkeys, pigs, chickens, geese, turkeys, herding dogs and livestock guarding dogs. Consult the website for instructions on submitting claims.

From 1987 to 2004, Defenders of Wildlife paid a total of approximately \$182,000 in claims in the State of Montana (Figure 6). Between 2000 and 2004, the average per year was $\$ 26,000$, although the annual amount ranged from $\$ 7,935$ to $\$ 54,757$.

\section{Development of a Montana-based Reimbursement Program}

The Montana Wolf Conservation and Management Plan called for creation of a Montana-based program to address the economic impacts of verified wolf-caused livestock losses. The plan identified the need for an entity independent from MFWP to administer the program. The plan also identified that the reimbursement program would be funded through sources independent from MFWP's wolf management dollars and other MFWP funds intended for fish and wildlife management.

In keeping with Montana's tradition of broad-based citizen participation in wolf conservation and management, a diverse, 30-member working group met 4 times in 2005. The working group was comprised of private citizens, representatives from non -governmental organizations, and representatives from state and federal agencies. The group agreed to a general draft framework that seeks to decrease risk of livestock loss by employing a variety of proactive techniques and to reimburse damages when they occur. A smaller subcommittee continues to meet into 2006. Their work is still ongoing.

Of particular concern to all participants was the need to secure funding for both the proactive work and the loss reimbursement components of the Montana wolf program. The working group explored a variety of funding mechanisms. The creation of an adequately funded loss reduction and damage mitigation program will help determine the degree to which people will share the land with wolves, to which the success of wolf recovery can be assured into the future, and the degree to which individual livestock operators who are adversely affected economically by wolf recovery are able to remain viable. Maintaining private lands in agricultural production provides habitat for a wide variety of wildlife in Montana and is vital to wolf conservation in the long run. 


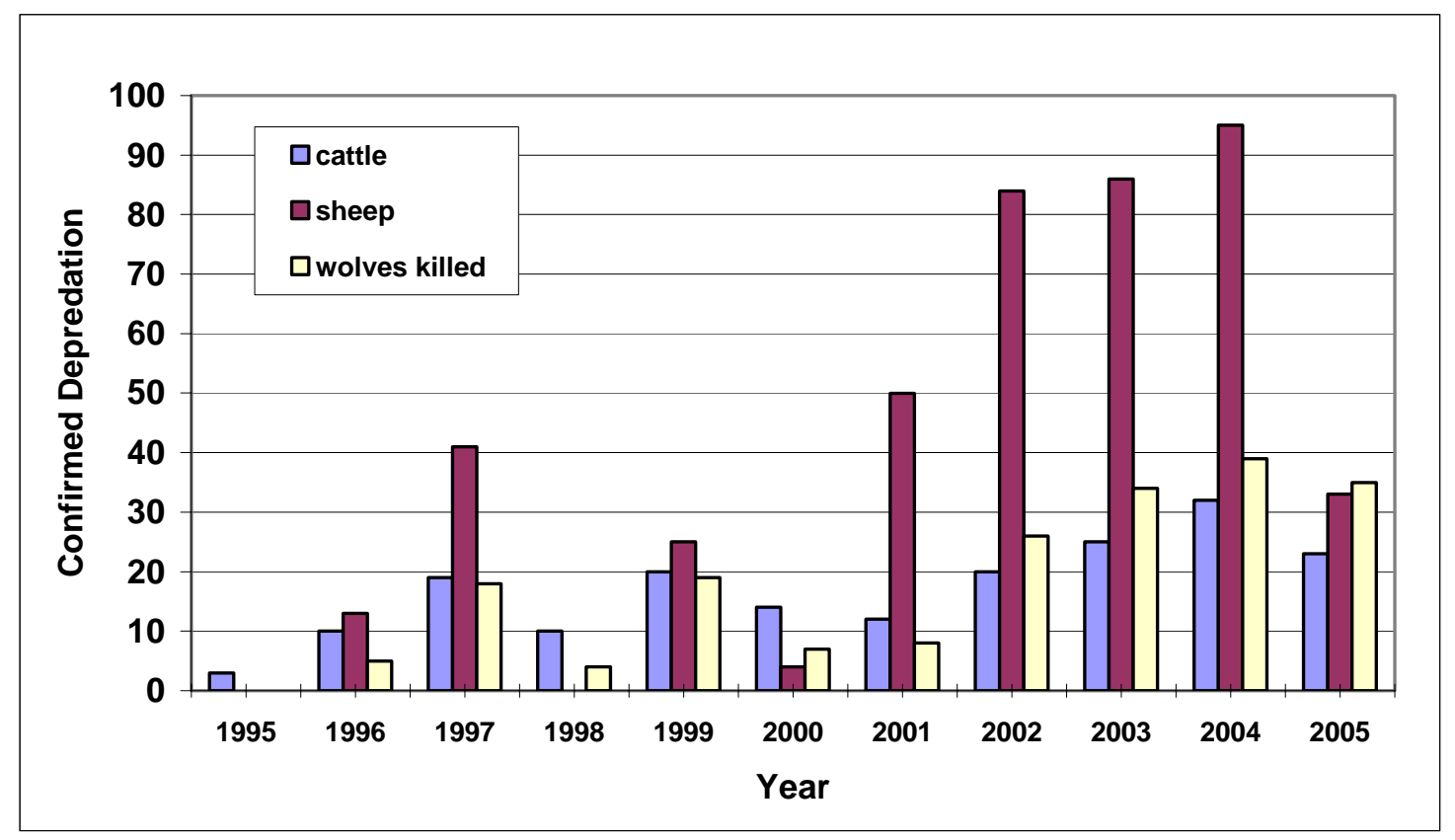

Figure 5. Confirmed cattle and sheep depredation and the number of wolves lethally controlled in the State of Montana based on investigations by USDA Wildlife Services, 19952005.

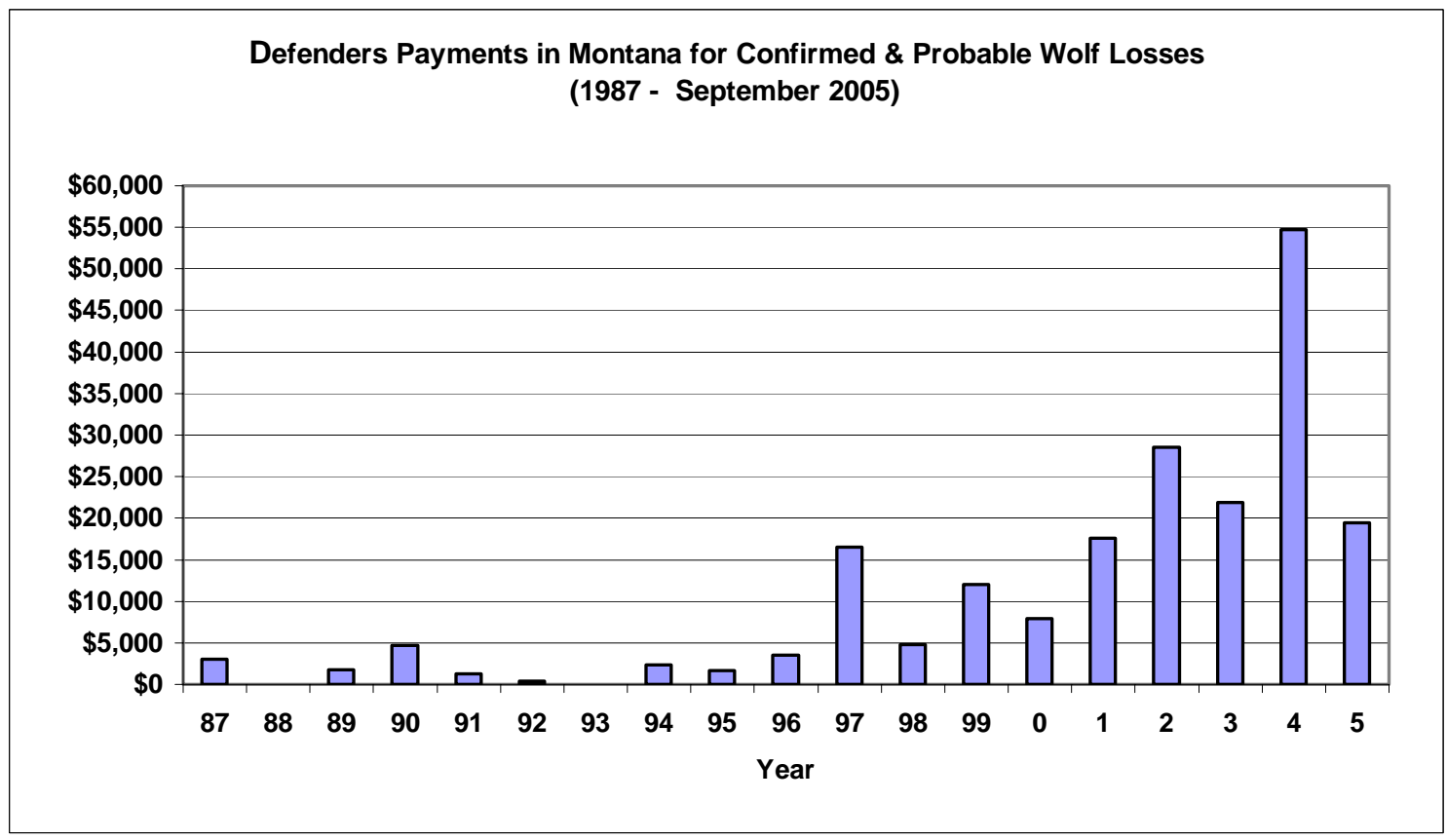

Figure 6. Compensation payments paid in Montana by Defenders of Wildlife, through September 2005. Source: http://www.defenders.org/wolfcomp.html. 


\section{PACK SUMMARIES}

\section{Northwest Montana Endangered Area}

\section{Overview}

MFWP captured 11 wolves in the Montana Portion of the NWMT recovery area in 2005. Seven were newly radio collared, 1 was recollared, and 4 were too small to collar and released. The Nez Perce Tribe (NPT) captured and collared 2 wolves in the Fish Creek Pack. WS wildlife specialist, Theodore North, collared 2 wolves that were incidentally captured by a fur trapper.

At the end of 2005, 20 radio collared wolves (16\% of the population) from 13 packs or pairs were being monitored in northwest Montana. These packs, together with uncollared packs that were documented, totaled 19 packs containing 126 wolves in the Montana portion of the NWMT recovery area (Figs 1, 2; Tables 1a, 4a). One radio collared pack, Kootenai North (formerly Kootenai) appears to be spending most, if not all, of its time north of the U.S. border. Radio collared wolves were located from aircraft approximately 1 - 2 times per month. Radio collared wolves in and around GNP were located more frequently from the ground by GNP staff.

Packs included in the Montana portion of the NWMT recovery area as of December 2005 were: Candy Mountain, Fish Creek, Fishtrap, Great Bear, Halfway, Hog Heaven, Kintla, Kootenai South, Lazy Creek, Livermore, Marias, Murphy Lake, Ninemile, Red Shale, Spotted Bear, Spotted Dog, Superior, Whitefish, and Wolf Prairie. There was not enough information in the Lonepine area to distinguish from the Hog Heaven Pack, so that pack is no longer counted. Newly documented wolf packs included the Livermore, Marias, Spotted Dog and Superior Packs.

The former Kootenai Pack territory, spanning the Montana and British Columbia border, appears now to be occupied by 2 packs. They are now referred to as Kootenai North (Canada), and Kootenai South (U.S.). Kootenai South likely denned in Montana and will therefore be counted as a NWMT pack in 2005. Kootenai North was counted as a NWMT pack since they were not located in the United States during 2005. Along the transboundary area between Montana and the Idaho Panhandle, the Calder Mountain pack was documented through the cooperative efforts of Idaho Department of Fish and Game and MFWP. It was believed to have denned in Idaho and was therefore counted towards the Idaho wolf population. Along the transboundary area between the NWMT and CID recovery areas, the Fish Creek pack was counted in the NWMT population.

Reproduction was confirmed in the Candy Mountain, Fish Creek, Fishtrap, Halfway, Kintla, Kootenai South, Lazy Creek, Murphy Lake, Ninemile, Red Shale, Spotted Bear and Wolf Prairie packs. Ten of these packs met the criterion to be counted as breeding pairs. Pup survival was uncertain in the Fishtrap pack. Pup production was uncertain in the Hog Heaven and Whitefish packs. The breeding status of the Great Bear, Livermore, Marias, Spotted Dog, and Superior packs was unknown because project personnel could not confirm denning activity and no pups were subsequently observed or reported by the public. 
Ten wolf mortalities were documented in the Montana portion of the NWMT recovery area population in 2005. The causes of death included 3 illegal kills, 2 vehicle collisions, 2 lethally removed in a control action, and 3 from unknown causes. A total of 3 radio-collared wolves (Fish trap, Kintla, and Whitefish), were missing due to either radio collar failure or dispersal.

\section{Verified Packs}

\section{Candy Mountain}

- 9 wolves; breeding pair

- no depredations reported

History: The Candy Mountain pack was first discovered as a new pair and an adult female (351) was radio collared in 2003. In 2004, denning was suspected but breeding pair status could not be verified. This is the first year this pack counted as a breeding pair. The Candy Mountain territory is in the Yaak River drainage.

2005 Activities: In February, this pack numbered 5-6 wolves. On August 2, a 3-year-old female was captured and collared. On August 4, a $38 \mathrm{lb}$ female pup was captured, but it was too small to collar and was released. By the end of 2005, this pack numbered 9 animals (5 adults, 4 pups), which is the highest documented for this pack.

\section{Fish Creek}

- 12 wolves; breeding pair

- no depredations reported

History: The Fish Creek pack was first documented in 2001 and is believed to have had a continuous tenure in the Fish Creek area since then.

2005 Activities: This pack was uncollared in January of 2005. In May, a black bear hunter reported seeing 5 wolves near the Fish Creek drainage. NPT personnel were working in the area and followed up in June and counted 9 pups ( 3 gray, 6 black). They set traps and captured a breeding female and an adult male. At this time, it was unknown whether this was the Fish Creek pack or the Lupine pack. Monitoring through the rest of 2005 found this pack using a territory most similar to the Fish Creek pack. Though they are considered a Montana/Idaho border pack, the Fish Creek pack is still counted as a Montana pack for 2005 since they denned in Montana and the majority of 2005 aerial telemetry locations were in Montana.

\section{Fishtrap}

- 7 wolves; not a breeding pair

- 1 calf confirmed killed, 1 sheep confirmed killed

History: The Fishtrap pack was first documented in 2000. Its territory is in and around the Thompson River drainage. 
2005 Activities: In February, this pack numbered 8-9 wolves. One pup was seen on May 11. Three radio collars were monitored throughout most of 2005 and therefore no trapping to radio collar was conducted. In August, a calf was confirmed injured by wolves. That calf later died of the injuries. The cattle were on a public grazing allotment and most non-lethal tools were not practical for widely distributed cattle. In October, 8-9 wolves were seen during a monitoring flight, and it could not be determined how many, if any, were pups. In October, a sheep was confirmed killed. . The owner penned them close to the ranch house to prevent further depredations. By the end of 2005 this pack numbered seven animals and \#326 has been missing since fall. The number of pups was unknown, and there was not enough information to confirm this pack as a breeding pair.

\section{Great Bear}

- 2 wolves; not a breeding pair

- no depredations reported

History: The Great Bear pack was first discovered as a new pair in 2003 after a wolf dispersed from the Spotted Bear pack and paired with another wolf of unknown origin. This pack inhabits in the Great Bear Wilderness. In early 2004, the radio collar could no longer be located.

2005 Activities: This pack was known to have 7 animals during the 2004/2005 winter. U.S. Forest Service personnel reported a minimum of 2 wolves during summer and fall. There are no functioning radio collars in this pack. We relied on agency and public reports, and they have been reliable and consistent. There was no further information regarding either wolf numbers or breeding status this year.

$\underline{\text { Halfway }}$

- 7 wolves; breeding pair

- 2 calves confirmed killed; 1 calf confirmed injured / euthanized; 1 wolf removed by WS

History: The Halfway pack was first documented in its current territory between Avon and Helmville in 2002. It was believed to have been started by a female member of the nearby Castle Rock pack, which was eliminated in 2002 after repeated livestock depredations. Throughout most of 2002, 2003 and 2004, it was probably 2 or 3 wolves. In August 2004, the Halfway pack was joined by a male wolf that had dispersed from a pack near Calgary, Alberta Canada. The male was wearing a GPS-satellite radio collar and appeared to have crossed the international border on the east side of GNP in mid-May 2004, and continued traveling south down the east Front of the Rockies.

2005 Activities: The GPS collar worn by the male wolf detached as scheduled and was retrieved within the normal home range of the Halfway pack in January 2005. It was returned to colleagues in Alberta. The pack was located in its usual home range throughout 2005. In March, 2 calves were confirmed killed. Calving operations were dispersed throughout the entire Halfway's pack territory so non-lethal deterrents were not practical. The adult male, known to have had been involved in cattle depredations in Alberta, was killed by WS. In April, another calf was confirmed injured by wolves and was later 
euthanized. Other calves had their tails bitten off. This pack produced a litter of pups, but it was rarely seen together during monitoring flights. Reliable reports indicated the pups survived, as 7 animals are reported consistently by area landowners at the end of 2005.

\section{Hog Heaven}

- 3 wolves; not a breeding pair

- no depredations reported

History: The Hog Heaven pack was first observed as a new pair in 2001, after 2 wolves from the Parsnip group (a group of wolves translocated from the Boulder Creek pack as a management response to cattle depredations), traveled separately to the Hog Heaven/Browns Meadow area and paired. The alpha female died in March of 2004 and the pack numbered only three animals by the end of that year. Its territory is west of Flathead Lake.

2005 Activities: This pack had 3 wolves prior to this year's denning season. It was never clear whether Hog Heaven denned and subsequently reared pups. An adult wolf was found dead on November 14. This mortality is under investigation. By the end of the year, 3 wolves were still being observed in the Hog Heaven pack, and it is not known whether the additional wolf was a pup or another adult. This pack was not a breeding pair.

\section{$\underline{\text { Kintla }}$}

- 9 wolves; breeding pair

- no depredations reported

History: The Kintla pack was first documented as a pack in 2000 in the old North Camas territory. The North Camas pack had previously existed from 1990 to 1996 and then fell apart as the neighboring South Camas pack grew to 18 animals in 1997. From 1997 to 1999, South Camas appeared to be the only pack in the area until 2000, when the Kintla pack established itself in the old North Camas territory. (See Whitefish pack summary below for additional historical information). Much of Kintla's home range is within GNP and in the North Fork Flathead River drainage.

2005 Activities: In February, this pack numbered 7 wolves. Three pups were observed on July 12. On December 21, a dead wolf was retrieved from the southern extent of the Kintla pack home range and the cause of mortality was unknown. At the end of 2005, Kintla had 6 adults and 3 pups.

\section{$\underline{\text { Kootenai }}$}

It is believed that the Kootenai pack is now functioning as 2 different packs.

History: This pack's home range historically covered an area of about 15-20 miles on either side of the U.S./Canada border west of Koocanusa Reservoir. It was established in part by an adult female (a Grave Creek pack disperser \#133 in 2001). She appeared to have denned in Canada about 15 miles north of the border. In 2004, that pack denned for the first time on the U.S. side and was counted in the NWMT population estimate. The original radio collared animal \#133 is missing, and we assumed the collar was no longer functioning due to its age. 
The remaining radio collar \#329 (captured in June 2004), has not been located in the U.S. since December 16, 2004.

2005: Since spring 2005, \#329 has been located north of the border consistently. Concurrently, on August 3, an active rendezvous site was found in the former Kootenai Pack territory. This active rendezvous site was about 4 miles from the previous year's den site or about 15 miles from \#329M's locations. Two animals were captured and collared at that newly discovered rendezvous site in August 2005. All 3 collars (1 in North and 2 in South Kootenai packs, respectively) were monitored throughout 2005. Through 2005, there did not seem to be a relationship between \#329M and the other 2 collared wolves. The resulting 2 packs are now named Kootenai North (Canada) and Kootenai South (U.S.)

\section{Kootenai North}

- 4 wolves; unknown breeding status; not counted in Montana population estimate

- no depredations reported

2005 Activities: Adult male wolf \#329M was located in Canada during the denning season and was located again until August. During this period, another pack of wolves was found about 4 miles from the 2004 den site in the U.S. The Kootenai North pack was monitored in Canada to determine their location and breeding status as it related to the southern group and NW Montana populations. Because this pack was located in Canada much or all of 2005, it was not counted towards the NWMT population. We will continue to monitor the collared animal from the south side of the border.

\section{Kootenai South}

- 7 wolves; breeding pair

- no depredations reported

2005 Activities: On August 3, a rendezvous site was discovered about 4 miles from the Kootenai Pack 2004 den area. On August 4, a $33 \mathrm{lb}$ female pup was captured and released because it was too small to collar. On August 5, a $39 \mathrm{lb}$ male pup was captured, and it was also released because it was too small to collar. On August 14, a $105 \mathrm{lb}$ 2-year-old male was captured and collared. On August 17, a $74 \mathrm{lb}$ 2-year-old female was captured and collared. During this period, the former Kootenai collared wolf \#329M was known to be in Canada about 15 miles north of the border. The Kootenai South territory is west of Koocanusa Reservoir, in the upper E Fork Yaak River. It had 5 adults and 2 pups at the end of the year.

\section{Lazy Creek}

- 9 wolves; breeding pair

- no depredations reported

History: The Lazy Creek pack was first discovered as a newly formed pair in 2001. This pack filled the vacant territory left by the Whitefish pack when it crossed the Whitefish range to the east and displaced the South Camas pack in 2001. Its territory is north of Whitefish Lake. 
2005 Activities: In January, this pack numbered 5 wolves. Since February, it had 4 members after 1 radio-collared animal was missing. On June 20, a 2 or 3-year-old male was captured and collared. By the end of the year, this pack was the largest ever recorded with 9 members (4 adults, 5 pups).

\section{Livermore}

- 4 wolves; not a breeding pair

- no depredations reported

History: The history of this pack prior to 2005 is unknown.

2005 Activities: A Blackfeet Tribe wildlife biologist discovered and photographed this pack at a bait station used to lure and capture grizzly bears.

\section{Marias}

- 6 wolves; not a breeding pair

- no depredations reported

History: New pack in 2005.

2005 Activities: On December 12, an adult male was killed by a vehicle on Highway 2 near Marias Pass. After that incident, MFWP, GNP, and the Blackfeet Tribe biologists received numerous wolf reports that were later verified. Six wolves occupied an area that included southern GNP, the Blackfeet Reservation, and the Lewis and Clark National Forest.

\section{Murphy Lake}

- 3 wolves; not a breeding pair

- no depredations reported

History: The Murphy Lake pack was first documented 14 years ago in 1991. This pack has had confirmed depredations in only 2 of the last 14 years. Its territory is between Whitefish and Eureka.

2005 Activities: Although we reported only 2 animals in the pack at the end of 2004, subsequent tracking in early winter 2005 suggested 4-5 five animals just prior to denning. There were several visuals of an unknown radio collared animal, which was assumed to be the alpha female, wearing a non-functional radio collar. On, May 14, a different female wolf was recaptured and recollared. On May 16, a 2 or 3-year-old male wolf was captured and collared. A collared wolf was found dead in July, and the mortality is under investigation. On September 22, 6 wolves were observed. At the end of the year, visual observations confirmed the presence of 3 animals in this pack.

Ninemile

- 7 wolves; breeding pair

- no depredations reported 
History: The Ninemile pack has inhabited the Ninemile drainage since 1990.

2005 Activities: In January 2005, 3 wolves were thought to be in the Ninemile pack, 2 gray adults and a radio-collared black yearling male (499M). In July, MFWP personnel documented 5 pups ( 4 black and 1 gray). In October, a male wolf was found dead and the carcass was taken to the MFWP Wildlife Lab in Bozeman. Cause of death could not be determined because of advanced decomposition of the carcass. Two wolves were incidentally captured by trappers in October and December, 2005. Each was collared and released with the help of WS. At the end of 2005, 7 wolves were documented in this pack: 2 gray adults, 1 gray pup, and 4 black pups.

\section{$\underline{\text { Red Shale }}$}

- 7 wolves; breeding pair

- no depredations reported

History: The Red Shale pack (historically referred to as Gates Park or Sun River) was first documented as a pair in 2000 and was believed to have had a continuous tenure in the North Fork of the Sun River ever since. This pack was radio collared in 2002, but has not had a functioning collar since March 2004. Monitoring this pack was coordinated between MFWP and U.S. Forest Service. We rely on agency and public reports to confirm wolf activity and numbers.

2005 Activities: This pack has not had a functioning radio collar since March 2004. Pack information in 2005 was provided by the U.S. Forest Service and public reports. The pack seemed to use traditional areas. The pack had 4 adults and 3 pups at the end of the year.

\section{Spotted Bear}

- 6 wolves, breeding pair

- no depredations reported

History: A Murphy Lake female wolf dispersed to the Bitterroot Valley and mated with an unknown male wolf forming the Bass Creek pack in 1998. The Bass Creek pack was involved in cattle depredations in June, 1999. The entire pack (8 pups and 2 adults) was removed from the wild and held at a facility in McCall, Idaho. The alpha male died in a handling accident while in captivity. The alpha female and surviving pups were translocated to a holding pen in the Spotted Bear drainage of the South Fork of the Flathead River in December, 1999. This pen was intended to hold the pack for several days to allow acclimation to the new area in hopes that the pack would settle in that area on the edge of the Bob Marshall Wilderness. The first night that the pack was held in the pen, a male wolf \#117 from the Pleasant Valley pack, translocated to the same area almost a year previous, was hanging around the pen. The Bass Creek pack was released the next day and joined with the former Pleasant Valley male wolf. The new group established a territory and became the Spotted Bear pack.

2005 Activities: This pack was uncollared from January through the middle of September 2005, but wolf activity was confirmed by U.S. Forest Service personnel and public reports. 
On September 12, during MFWP trapping operations, the pack was observed with 6-7 total wolves - having at least two pups, and a very light gray animal wearing a radio collar. We assumed this animal is the original alpha female whose collar is no longer functioning. On September 13, a 105 lb 2-year-old male wolf was captured and radio collared. On September 15, the wolf was located 19 miles north of his capture location. On September 18, he was located on the west side of the reservoir after apparently swimming it. In that general area, the reservoir is about $3 / 4$ mile across at its narrowest point. The wolf could not be located through the fall months but was later found again within the normal Spotted Bear home range in December. This pack had 4 adults and 2 pups at the end of the year.

\section{Spotted Dog}

- 11 wolves; not a breeding pair

- 1 calf confirmed killed

History: The Spotted Dog pack was first verified in July 2005, but was believed to have existed the previous year, possibly longer. MFWP first received reports in the area from landowners, contractors, and hunters in late 2004. Its territory appeared to be primarily south of Avon, but reports of at least 8 animals were received north of Avon.

2005 Activities: Seven animals were reported early in 2005 by local landowners and contractors working in the area. Efforts were made to place a collar in this pack in July, September, and October. Area landowners and contractors consistently reported up to 11 animals in the same general area through December 2005. We suspected that pups were produced based on the wolf numbers reported at the end of 2005. Because pups were never observed or verified, this pack did not qualify as a breeding pair.

\section{$\underline{\text { Superior }}$}

- at least 2 wolves; not a breeding pair

- 1 colt confirmed injured

History: New pack in 2005.

2005 Activities: Wolf activity was reported south of Superior in spring, 2005. In June, a colt was confirmed attacked by wolves but survived. WS initiated a trapping effort to collar and release but nothing was caught. MFWP volunteers also surveyed the area and were unable to turn up much fresh sign. Reports continued to come in during hunting season. MFWP personnel cut tracks of two wolves in the area in December 2005. No reproduction was documented. Based on sightings, this pack is believed to be a Montana/Idaho border pack but probably spends the majority of its time in Montana.

\section{Whitefish}

- 7 wolves; not a breeding pair

- no depredations reported

History: The Whitefish pack was first documented in 1996 and formerly occupied a territory north of Whitefish Lake. In 2001, the Whitefish pack crossed the Whitefish Range to the 
east and established a new territory in the North Fork Flathead River drainage, displacing the former South Camas pack. Much of the Whitefish pack's home range is now within GNP.

2005 Activities: Prior to denning, this pack numbered 6-7 wolves, including 1 gray and 5-6 black. The pack localized during the denning season, but no pups were ever documented. This pack still has 1 gray and 6 black wolves at the end of 2005.

\section{Wolf Prairie}

- 8 wolves; breeding pair

- 1 probable calf killed

History: The Wolf Prairie pack was first documented in 2004, after receiving livestock depredation complaints. Its territory is west of Kalispell.

2005 Activities: This pack numbered 4 wolves prior to the denning season. In April, a calf was determined a probable kill approximately 2 miles from the Wolf Prairie pack den site. A Radio Activated Guard (RAG) Box was set up to deter further incidents and warn the operators of any nearby collared wolves. No further losses occurred. Pups were observed on May 27. On September 11, a wolf was hit and killed on Wolf Creek Road, within the Wolf Prairie home range. It was assumed to be from of the Wolf Prairie pack. On December 19, we observed 8 wolves ( 3 adults, 5 pups), which is the largest recorded since they have been monitored.

\section{Miscellaneous / Lone Individuals}

On April 6, wS lethally removed an adult female lone wolf that had been involved in cattle depredations on the Blackfeet Reservation. This animal had extensive mange. It was thought to be a lone animal.

On September 29, a Montana Department of Natural Resources and Conservation forester reported a wolf carcass. The carcass was in advanced stages of decomposition but was confirmed to be less than two years old but sex was unknown. The specific cause of death is unknown. Its pack affiliation was unknown, but the carcass was found in an area between Murphy Lake, Lazy Creek, and the former Grave Creek packs.

On November 11, hunters reported a wolf carcass in an area near the former Apgar pack territory. This mortality is under investigation. There area other unverified wolf reports in this area.

On November 16, a 2-3 year old uncollared male wolf was struck and killed by a vehicle on Highway 200 west of the continental divide and a few miles east of Lincoln. The closest verified packs were the Halfway, Spotted Dog, and the Red Shale packs. Numerous wolf reports were obtained on the east side of the continental divide between Stemple Pass and Highway 12 to the south. Scouting efforts in this area late in 2005 and in the Alice Creek area near Lincoln did not 
verify a pack. So, it is unknown whether this male was affiliated with a nearby pack or a single disperser.

There is a U.S./Canada transboundary group of wolves on the east side of Glacier and Waterton Lakes parks. Numbers fluctuated widely in reports and through time. Reports indicated that these wolves most of their time in Canada and therefore are not counted in the Montana portion of the NWMT recovery area.

\section{Suspected Packs}

DeBorgia: During archery and rifle season 2005, MFWP personnel received several reports of wolves south of the town of DeBorgia in western Montana. Reports indicate a pack possibly as large as 6+ wolves. MFWP personnel will be investigating this area in 2006.

Frenchtown/Dixon: Landowners north of Frenchtown (west of Missoula) reported seeing a group of 5 wolves (1 black, 4 gray) in this area on several occasions during fall 2005. There also were several sightings near Dixon to the northwest of Missoula, one by a Confederated Salish and Kootenai Tribe game warden, who reported seeing 5 wolves. The Ninemile pack was not located out of the Ninemile drainage in 2005 and the pelage colors did not match up with the Ninemile pack; therefore this is an area of new suspected wolf activity for 2005.

\section{Other Miscellaneous Information}

Lonepine: There wasn't enough information in the Lonepine area to distinguish it from the Hog Heaven Pack so that pack was no longer counted.

\section{Southern Montana Experimental Area}

\section{Montana Portion of the Greater Yellowstone Experimental Area}

\section{Overview}

Packs in the Montana portion of the GYA have been documented from Red Lodge to Dillon. Several packs live on the borders of YNP. Both agencies (YNP and MFWP) monitor these packs through flights and ground tracking. The location of den sites and the percent area / time in an area determine where that pack will be tallied in the population estimates. See the respective pack summaries below.

Twenty-one packs were monitored at 1 point or another during 2005, but only 16 packs in the Montana portion of the GYA were still present at the end of 2005. Of the 16 left at the end of the year, only 3 met the breeding pair criteria. We partly attributed this decline in breeding pairs to mange, which seemed to negatively affect pup survival for 2005. Eight packs had individuals confirmed to be infected with mange. Heavy lethal control on chronic depredating packs late in 2004 and early 2005 may also have been a factor. We did not document the wolves recolonizing vacant territories (i.e. "backfill”) during wolf breeding season (January / February). Lower wolf 
numbers inside YNP could also partly explained the difference, as fewer animals in the YNP population may translate to fewer animals dispersing out of YNP into Montana.

During 2005, 6 packs out of the original 21 present in January 2005, were involved in confirmed depredations on domestic livestock or dogs (Table 1b), resulting in the lethal removal of 19 wolves. Two of the 6 packs no longer exist. Overall livestock conflicts and the amount of lethal control were both less in 2005 than in 2004.

MFWP and WS staff radio collared seven wolves in this area in 2005. Seven collared animals from the previous year were lost due to control actions or natural mortalities. One wolf collared in 2005 was controlled making a total of eight collars lost in 2005. Three collared animals are considered missing. By December 31, 11 wolves wore active radio collars, and 10 packs had at least one collar.

Project staff documented the dispersal of 3 wolves from their natal territories, two of which successfully formed their own packs (Deadhorse and Donohue). Another dispersing male joined the existing Moccasin Lake pack.

\section{Verified Packs}

\section{Mill Creek}

- 2 wolves; not a breeding pair

- 2 shoot-on-sight permits issued to private landowners in December 2004; 2 pups removed by permit early 2005; no depredations reported in 2005

History: The Mill Creek pack formed in 2000. It spent a fair amount of time on or near private property on the east side of Paradise Valley and the Yellowstone River. Numerous livestock depredations (cattle and sheep) were confirmed on private property in 2004.

2005 Activities: Due to repeated livestock depredations in 2004, lethal control was ongoing in January 2005. Shoot-on-sight permits had been issued to landowners in December 2004. Two pups were shot under the permit in January 2005, and both had severe cases of mange. The breeding female remained in the Mill Creek territory. Although few visuals were obtained, she appeared to look unaffected by the mange parasite and seemed to be traveling alone most of the year. She did not successfully whelp and raise pups this year. A telemetry flight in December 2005 confirmed she was with 1 other black wolf.

\section{Lone Bear}

- no longer exists

- 3 wolves removed by WS

History: The Lone Bear pack formed in 2002. It spent a fair amount of time on or near private property at the northwest end Paradise Valley. Numerous livestock depredations (mostly sheep) were confirmed on private property in 2004. 
2005 Activities: Repeated sheep depredations were confirmed on private property in 2004. Control actions were ongoing in January 2005 to remove the remaining wolves in the Lone Bear pack territory. A total of 3 wolves were killed in January and February. A female originally collared in the Lone Bear territory dispersed from the area and moved south. It was found in early February traveling with an unmarked gray wolf. They started the Donahue pack in 2005 (see below).

\section{Casey Lake}

- 3 wolves; not a breeding pair

- no depredations reported

History: The Casey Lake pack formed in 2004. Its territory is north of YNP on the east side of the Yellowstone River in the Paradise Valley. Three pups were caught in August 2004, all of which showed signs of being infected with the mange parasite. Nonetheless, the pack was intact at the end of 2004 and it qualified as a breeding pair.

2005 Activities: The presence of mange appears to have disrupted this pack in 2005. An adult male wolf died of mange in March and his carcass was retrieved. Project personnel did not find evidence that the pack was still intact through the summer months and no pups were produced in 2005. However, winter snow tracking at the end of 2005 confirmed the presence of at least 3 animals in the Casey Lake territory.

\section{Donahue}

- 2 wolves, not a breeding pair

- no depredation reported

History: New pack in 2005

2005 Activities: A disperser from the Lone Bear pack moved south and was found traveling with an unmarked gray wolf as early as February 2005. Although breeding status was unknown, residents reported two adults and three pups in the Donohue/Hyalite areas of Paradise Valley during the summer. The last location of this pack was obtained in September and its status is unknown.

\section{Beartrap}

- 8 wolves; breeding pair

- no depredations reported

History: The Beartrap pack formed in 2002. It occupied a territory at the north end of the Gallatin Mountain range near the Spanish Peaks consistently since then.

2005 Activities: Two adults and 1 yearling were documented prior to April 2005. Although no collars existed in this pack, consistent sightings by project personnel and landowners indicated that pups were produced and the pack was together and still in the same territory. 


\section{Freezeout Pack}

- 5 wolves; not a breeding pair

- 2 injured guard dogs confirmed and 2 calves confirmed killed; 6 wolves removed by WS; 3 shoot-on-sight permits issued but no wolves killed by permit

History: The Freezeout pack first formed in 2001 in the Gravelly Range east of Dillon. It has been one of the larger sized packs in the Montana portion of the GYA outside YNP.

2005 Activities: In early summer 2005, the Freezeout Pack was believed to be seven adults and three to four pups. In August, project personnel captured a pup and an adult male wolf. The pup had his collar chewed off by pack mates two days afterward. The adult male was fitted with a GPS radio collar as part of the cooperative wolf-ungulate research studies ongoing in southwest Montana. In September, 2 guard dogs were confirmed injured and one calf was confirmed killed in 2 separate incidents. Agency lethal control was authorized and WS removed 6 wolves, one of which was the GPS-collared individual. Shoot-on-sightpermits were issued to the livestock owners, but no wolves were taken by private citizens. No more depredations were reported in 2005. The GPS collar was redeployed on an adult female.

\section{Bear Creek}

- no longer exists

- no depredations reported

History: Bear Creek pack started as a pair of wolves in 2004 and the territory was in the Madison River drainage south of Ennis.

2005 Activities: This pack consisted of 2 animals, 1 of which was radio collared. The collared wolf was seen traveling alone outside of the Bear Creek territory through April and has not been located since. No activity in the area was documented or reported. The fate of the unmarked gray adult was unknown. The pair no longer exists.

\section{Chief Joseph}

- 5 wolves; not a breeding pair

- WS investigated 1 suspected depredation and concluded that the heifer died while giving birth and had been scavenged

History: The Chief Joseph pack began as a pair of wolves in 1996 in the northwest part of YNP. It started out primarily in YNP and had been counted as a YNP pack for most years. Although the pack consistently denned within the park boundary, it has spent more and more time in Montana. Through time, Montana project personnel did more of the monitoring. The Chief Joseph pack was included in the population estimate for the Montana portion of the GYA in 2005.

2005 Activities: An adult female wolf died of natural causes and her carcass was retrieved in March. Mange was suspected as this animal was seen during the hunting season of 2004 with extensive hair loss. A second animal was retrieved and confirmed hit by a car. It also 
had signs of hair loss. Den sites were investigated to determine if the pack had pups. Minimal evidence of pup production was found, so it was not a breeding pair for 2005. A radio collared adult male traveled alone during the second half of 2005. He also has mange. The status of this pack was somewhat unknown by the end of 2005. We believe there is still a pack with up to 5 animals remaining. Local landowners in the Paradise Valley consistently reported as many as 5 animals in areas traditionally used by this pack.

\section{Cougar Creek II}

- 8 wolves; border pack and counted in the YNP population

- no depredations reported

History: The Cougar Creek pack first formed in 2001 inside YNP. Its home range was mostly inside YNP and NPS personnel did all the monitoring. Since 2002, it has had 10 to 12 members.

2005 Activities: The Cougar Creek pack has been considered a YNP pack since 2001 and NPS personnel did all the monitoring. However, the pack appeared to split and some of its members began spending more time in Montana outside the Park, beginning in the fall of 2005. By November, 8 wolves appeared to be settling into a portion of the Chief Joseph pack's old territory. YNP and Montana personnel will be monitoring this new group in 2006.

\section{Deadhorse}

- 6 wolves; breeding pair

- no depredations reported

History: New pack in 2005.

2005 Activities: A dispersing male wolf from the Freezeout pack was found in the Upper Gallatin / Taylor Fork drainage in the spring. Four pups were successfully raised.

Wedge

- 8 wolves; breeding pair

- 1 confirmed injured heifer which was later euthanized; no control requested or authorized

History: New pack in 2005.

2005 Activities: In December 2004, project personnel found a female wolf, a disperser from the Leopold pack inside YNP, in the Upper Madison drainage. Two wolves were captured and radio collared. One received a regular VHF collar and the other was fitted with a GPS collar as part of the cooperative wolf ungulate research study (see Field Studies and Research section below). The pack denned and successfully raised a litter. In September, a wounded heifer was confirmed and later euthanized. No lethal control was requested and none was initiated. The collared dispersing female may have died late in the year. It could not be investigated in December due to the snow conditions in the remote mountainous area. It will be investigated as early in 2006 as backcountry conditions permit. Mange is suspected in this pack. 


\section{Homestead}

- no longer exists

- no depredations reported

History: New pack in 2005.

2005 Activities: Starting in January 2005, project personnel received reports of a black and gray wolf in the Bear and Indian Creek areas of the Upper Madison. Landowners began reporting a sickly pup in July. Upon investigation, a total of 4 wolves were found dead or subsequently euthanized due to severe mange. All carcasses were transported to the MFWP Lab for in-depth examination. All were confirmed to be in very poor condition and each had mange.

\section{Sage Creek}

- 6 wolves; not a breeding pair

- depredations in the area, unknown if this pack was involved

History: New pack in 2005.

2005 Activities: A dog was killed by wolves in Sage Creek in January. During a flight, WS saw 2 uncollared gray wolves 6 miles to the east of the ranch where the dog was attacked. One of the wolves was missing half of its tail and this pair came to be known as the 'Bobtail pair.' A calf was killed in the same area in March, and the same pair of wolves was believed responsible. In April, 7 buck sheep were killed in the Blacktail drainage and in October, 5 more buck sheep were killed in the same area. In early December, a guard dog was injured and 1 ewe was injured. During hunting season there were multiple reports of wolves in the upper Blacktail and upper Sage Creek drainages. WS flew the area on numerous occasions and MFWP investigated from the ground, but no wolves were found. Then in mid-January of 2006, while doing helicopter work on coyotes, WS found 6 gray wolves in Basin Creek and darted, collared and released an adult male. None of these wolves appeared to have a bobtail. In early 2006, numerous Dillon residents reported seeing a group of 3 wolves (1 black, 2 gray) just east of town. So it is unknown whether the 'Bobtail pair,' an unknown Dillon trio, or the Sage Creek pack was involved in the previous depredations.

\section{Phantom Lake}

- no longer exists

- 1 sheep and 2 calves confirmed, 1 probable calf 1 confirmed injured livestock guarding dog; 4 wolves removed by WS, 4 shoot-on-site permits issued but no wolves killed

History: The Phantom Lake pack formed in 2004. It was confirmed to have killed 13 calves and 49 sheep in the latter half of 2004. Two wolves were lethally controlled in 2004 and the pack did not meet breeding pair requirements. Control actions were initiated in 2004 and were completed in 2005.

2005 Activities: At the beginning of 2005, there appeared to be 3-4 wolves left in the pack occupying the area between the West Rosebud and Red Lodge along the north foothills of the 
Beartooth Plateau. Agency lethal control had been initiated because of repeated depredations in 2004. Between January 2005 and May 2005, several additional depredation incidents were confirmed on private property ( 1 ewe confirmed dead, 1 injured guard dog confirmed, 2 dead calves confirmed, 1 dead calf probable). Shoot-on-site permits were issued. WS removed a total of 4 wolves. No wolves were taken by private citizens on the permits. Wolf activity was not documented after June, and no further depredations were reported.

\section{$\underline{\text { Rosebud }}$}

- 3 wolves; not a breeding pair

- no depredations reported

History: New pack formed late in 2005.

2005 Activities: No wolves or wolf sign was reported in this area until October 2005. Public wolf reports indicated 3 animals traveling in the foothills of the Beartooth Plateau. In November, project personnel verified tracks of 3 animals between the West and East Rosebud drainages. Due to mild weather conditions, a brief trapping session was conducted in December, but no wolves were captured.

\section{Moccasin Lake}

- 2 wolves; not a breeding pair

- 2 probable calf depredations; range riders patrolled in their territory

History: This pack formed in 2004. Its territory is south of Big Timber.

2005 Activities: In January 2005, 4-5 wolves were thought to be present, 1 of which was collared. Although the pack seemed to localize during the denning period, no pups were ever seen with the pack. There were two probable calf depredations during the year. In both cases non-lethal techniques were used to deter further problems (see below). Project personnel trapped and collared a 2-year-old male in July (SW28M). Wolf SW28M was seen several times with the collared female (242F) and two other wolves until September-October. At that time, SW28M left the Moccasin Lake pack territory and seemed to settle in the Mission Creek territory to the west. Also in the October time frame, the Moccasin female 242F was joined by an adult male (473M) that had left the Swan Lake pack in YNP. From October to December, they were located together, but no other wolves were seen.

The Boulder Watershed Group's Wildlife Subcommittee received a grant from the Natural Resource Conservation Service, Environmental Quality Incentives Program. In partnership with MFWP, the U.S. Forest Service, and Bozeman-based Predator Conservation Alliance, the Watershed group hired 3 range riders for the period July - October to increase human presence in and around the livestock. It was hoped that increased human presence would discourage wolves from depredating livestock and that injured and dead livestock would be detected more rapidly. Two riders worked on public grazing allotments and 1 rider worked on private lands. See the Field Studies and Research section below for more detail on this project. 


\section{Mission Creek}

- 3 wolves; not a breeding pair

- no depredations reported

History: The Mission Creek pack first formed in 2002. Its territory is southeast of Livingston.

2005 Activities: Pack dynamics appeared to be greatly affected by mange in 2005. A visual early in the year revealed 4 wolves, with 3 showing severe mange and 1 with a mild case. The two collared wolves were often separated when located during telemetry flights. There was no evidence of successful breeding. In October, the alpha male succumbed to mange and died. Also in October, 457F was seen with SW28M (formerly of the Moccasin Lake pack). In subsequent flights, 457F seemed to be traveling independently of SW28M. The status of the other Mission Creek wolves was unknown.

\section{$\underline{S W 28 M}$}

- 2 wolves; not a breeding pair

- no depredations reported

History: This group formed in late fall, 2005. Its territory slightly overlapped the Mission Creek territory.

2005 Activities: This group consists of a 2-year-old male wolf (SW28M, caught in Moccasin Lake territory in July 2005) and another wolf of unknown origin. In October, SW28M was seen traveling with 457F. He looked healthy, but she was showing obvious signs of mange. In subsequent flights SW28M was seen traveling with another, uncollared gray wolf. It is unclear if $457 \mathrm{~F}$ is still with members of the Mission Creek pack, or if she was moving alone.

\section{$\underline{\text { SW57 }}$}

- 2 wolves; not a breeding pair

- 1 confirmed calf; 1 wolf shot under the $10(\mathrm{j})$

History: This group was documented in fall 2005. Its territory slightly overlapped the Mission Creek territory.

2005 Activities: In October WS confirmed that wolves had killed a calf, and traps were set to gain more information. A gray colored wolf (SW57F) was captured at the site. Further monitoring showed that this collared wolf and at least one other was occupying a small area between the Moccasin Lake and Mission Creek packs, but remaining separated from them. In December, a ranch manager in the West Boulder drainage saw three wolves chasing his cattle. The ranch manager shot one wolf as per the 10(j) regulations before any cattle were injured or killed. SW57F continued to move in the area between the Moccasin Lake and Mission Creek / SW28M packs. 


\section{Carbonate Mountain}

- 5 wolves; not a breeding pair

- no depredations reported

History: New in 2005. The home range of this pack was unclear, but activity has been verified in the Boulder drainage and near Carbonate Mountain in the Absaroka-Beartooth Wilderness.

2005 Activities: Public reports of wolves in the area around Carbonate Mountain in the Absaroka Beartooth Wilderness were received beginning in September. Numerous hunters and the local MFWP game warden reported seeing 3-5 wolves. In past years, there had been wolf activity in this area occasionally. Project personnel were able to establish a trap line for a few days before hunting season started. Although there was evidence that 5 wolves had been in the area, none were captured.

\section{Buffalo Fork}

- 2 wolves; not a breeding pair

- no depredations reported

History: The Buffalo Fork pack formed in 2003. In June 2003, the only radio-collared member of the pack died and contact was lost. At the end of the year, 3 wolves were believed to be left in the pack. Its territory was north of YNP in the Buffalo Fork drainage. There is no evidence that any of this pack's territory was in YNP in 2005.

2005 Activities: Numerous public reports were received from backcountry recreationists. In July 2005, project personnel backpacked through the historic Buffalo Fork territory in the Absaroka Beartooth Wilderness to look for wolf sign and listen for missing collars. Fresh wolf sign and evidence of at least 2 adults and 1 pup was found in the vicinity of the old territory. Because of the remote location of this pack, little is known about is status or size.

\section{Miscellaneous / Lone Individuals}

A female wolf dispersed from the Leopold pack and was found localized in the Jardine, Montana area just north of the YNP boundary for several spring and summer months. Her status and whether she associated with other wolves was unknown, as no visuals or reports of other wolves in the area were received in 2005. In late January 2006 she was recaptured during a YNP effort and is part of the Hellroaring pack, an offshoot of the Leopold pack. She was tallied in the GYA - YNP table.

A sick, unmarked wolf was found in a pasture and reported by a landowner north of Gardiner in April. Project personnel responded and euthanized the animal on site. Lab results showed this pup was severely dehydrated and that it had been exposed to canine parvo virus, canine distemper, and canine hepatitis at some point in its life. Histology did not reveal active viral infection at the time of its death. 
A lone, unmarked wolf was killed while harassing mules on private property in the Jardine, Montana area in March. The new 10(j) regulations had gone into effect by that time. This was the first wolf killed in Montana since the new regulation took effect.

In May, 12 sheep were confirmed killed on private property at the northwest end of the Paradise Valley. One unmarked gray was seen in the area. WS investigated and saw tracks of possibly 2 wolves. WS was authorized to remove up to 2 wolves, and traps were set on site to remove the offender/s. After 8 nights, the traps were pulled as no wolves had returned to the site.

On June 27, an uncollared yearling male wolf was struck and killed by a vehicle on Interstate 90 near Deer Lodge. The closest verified pack is Spotted Dog, but it was unknown if this wolf was affiliated with that pack. This mortality is tallied in the Montana portion of the GYA.

\section{Suspected Packs}

Wolf activity increased in December 2005 via reports from landowners in the Cameron, Montana area of the Madison valley. This area has supported wolf packs in the past, but conflicts with livestock or disease were factors leading up to the removal or disbanding of packs over the years. Project personnel will make efforts to radio collar animals in the area during the 2006 trapping season as activity continues to be reported.

\section{Other Miscellaneous Information}

Seven packs that were either verified or suspected to exist in 2004 no longer exist in the Montana wolf population. This was due to either the lack of any activity in the area over the last year or due to elimination of the pack because of chronic livestock depredations. Therefore, they were removed from the 2005 population table.

Redrock: southwest Montana; no sightings, reports, or wolf activity in 2005.

Sheep Mountain: Paradise Valley; pack eliminated due to chronic depredation in 2004.

Taylor Peak: Madison Valley; pack died out in 2004 and no longer exists due to mange.

Sentinel: Madison Valley; pack eliminated due to chronic depredations in 2004.

Ennis Lake: pack eliminated due to chronic depredations in 2004.

Red Lodge: south of Red Lodge; no sightings, reports, or wolf activity in 2005.

Dillon Pair: southwest Montana; pack eliminated due to chronic depredations in 2004. 


\section{Montana portion of the Central Idaho Experimental Area}

\section{Overview}

In 2005, a minimum estimate of 64 wolves in 11 packs was verified in the Montana portion of the CID. The population estimate has doubled in this area since 2004, partly due to increased field monitoring efforts and because the Big Hole pack (near Lolo Pass), which usually tallied in Idaho, denned and spent most of their time in Montana in 2005. The Big Hole pack counts as a Montana pack for the first time in 2005.

Packs that were verified in 2004 and still existed in 2005 are the Battlefield, Black Canyon, Painted Rocks, Big Hole, Sapphire, and Willow packs. New documented packs in 2005 include the Sula, Brooks Creek, and Skalkaho packs. The Lake Como pack, which had been verified in years prior to 2004, was verified again in 2005. And the Mt Haggin pack, which was suspected in 2004, was confirmed in 2005. The Grassy Top pack dropped off as a verified pack for 2005 due to few sightings in the area. This pack may still exist but may spend more time in Idaho.

At the end of 2005, 6 (55\%) of 11 packs were being monitored using ground and aerial telemetry. Six wolves in 5 packs were captured and radio-collared in the Montana portion of the CID in 2005. Five were collared during MFWP trapping efforts, and 1 was radio-collared by WS in response to a depredation. Radio-collared wolves were located 1-2 times per month by fixed-wing aircraft.

Seven of the 11 packs monitored in the MT portion of the CID occupy the Idaho/Montana border: Battlefield, Black Canyon, Painted Rocks, Big Hole, Sula, Lake Como, and Brooks Creek. The Battlefield, Big Hole, and Brooks Creek packs have been verified to spend time in Idaho. The others were only suspected to spend time in Idaho, based on proximity of sightings or telemetry locations. Because these 7 packs denned in Montana, or are known to have spent most of their time in Montana, they were counted as Montana packs for 2005. MFWP conducts most of the monitoring of these packs in close coordination with IDFG and the NPT, with the exception of the Big Hole pack, which was monitored by both the NPT and MFWP.

Reproduction was confirmed in 7 packs: Battlefield, Black Canyon, Painted Rocks, Big Hole, Sapphire, Willow, and Sula packs. A minimum estimate of 17 pups was produced and six packs (Battlefield, Sula, Willow, Sapphire, Big Hole, and Painted Rocks) met the breeding pair requirement. Only 1 pup was documented in the Black Canyon pack and the alpha female was killed before the end of the year. The Brooks Creek pack localized during denning season but no pups were ever seen or heard. Reproductive status of the Mt Haggin, Lake Como, and Skalkaho packs was unknown.

Two packs (Battlefield and Black Canyon) were confirmed to kill livestock. Fourteen wolves were killed in response to depredations: 5 were shot by private citizens [10(j)] and 9 by WS. Depredation and control statistics in this area were very similar to 2004. Two other wolves were known to have died: 1 was incidentally killed in a coyote snare and 1 died for unknown reasons. 


\section{Verified Packs}

\section{Battlefield}

- 5 wolves; breeding pair

- 4 calves, 1 horse, 1 foal confirmed killed; 6 wolves removed by WS and 3 wolves removed by private landowners under the new 10(j) regulation

History: Wolf packs have inhabited the Big Hole Valley intermittently for many years. Most wild ungulates migrate out of the valley during the winter season and conflicts with livestock developed each time a pack formed. The Battlefield pack formed in 2002. Conflicts with livestock in 2004 resulted in removal of 5 pack members.

2005 Activities: In January 2005, MFWP personnel documented 9 wolves in the Battlefield pack, including a radio-collared yearling female. Though there were 8 wolves at the end of 2004, a ninth black wolf appeared to be satelliting the pack at this time. During a routine monitoring flight in February, MFWP personnel located 4 members of the pack near a dead horse, which was later confirmed as a wolf kill by WS. At this time, at least 2 of the 4 observed wolves had signs of sarcoptic mange. A week later, 2 wolves (a female pup and an adult female) were killed by WS in the vicinity of the dead horse. Both showed signs of mange.

In early March, a landowner in the Big Hole Valley legally shot an adult male wolf under the 10(j) regulations. The wolf was chasing cattle on private land. This wolf turned out to be B144M, originally collared in the Moyer Basin pack in Idaho in early 2003. He dispersed at the end of 2003 and was caught in a coyote trap in Paradise Valley, Montana in December of 2003. He was monitored in Paradise Valley through spring of 2004 and then disappeared. He was found to be in breeding condition at the time of his mortality and was thought to have probably been the alpha male of the Battlefield pack. He showed signs of excessive hair loss and mange was confirmed by personnel at the MFWP Lab. Because mange had been found recently in Paradise Valley, it was speculated that B144M may have picked it up in Paradise Valley and brought it with him to the Big Hole. The landowner who shot B144M said he was traveling with another wolf that also appeared to have mange.

In mid-April, a second wolf (adult male) was caught chasing cattle on private property in the Big Hole Valley and was legally [10(j)] shot. In late April, a third wolf (adult male) was also caught chasing cattle on private property and was legally (10(j)) shot. In early May, a foal was confirmed killed by wolves. While control work was ongoing, 3 calves, in 2 separate incidents, were confirmed killed in late May. The collared Battlefield female appeared to be traveling alone at this time and could not be located with the remaining pack members. She was killed by WS in early July. At this time we suspected that 3 wolves were left, including the alpha female. Reproductive status was unknown at this time.

In September, another calf was confirmed killed and control efforts resumed. WS set traps and caught and killed 3 wolves ( 1 adult male, 1 female pup, and 1 male pup). The male pup was necropsied at the MFWP Lab was found to have a single dog-biting louse parasite. Lice have not been documented on wolves in Montana before but have been found on wolves in 
Alaska and Minnesota. At this time, WS also caught, radio-collared and released 1 female pup, thus confirming that indeed the pack had denned and produced pups in 2005. No other depredation incidents were documented through the rest of 2005.

Five wolves (2 adults, 3 pups), all gray, were seen during a MFWP monitoring flight in late October. Subsequent flights through the end of 2005 found the Battlefield pack in Idaho around the Gibbonsville area. Though it is considered a Montana/Idaho border pack, it is still counted as a Montana pack for 2005 since we believe it denned in Montana, livestock depredations occurred in Montana, and the majority of the territory is in Montana. No mange was documented in the Battlefield pack after B144M was shot, and it remains unknown whether other wolves in the pack recovered or were never infected. All 5 wolves appeared to have healthy coats at the end of 2005.

\section{Black Canyon}

- 4 wolves; not a breeding pair

- 3 yearling heifers and 6 sheep confirmed killed, 1 heifer confirmed injured, 1 colt confirmed injured, 1 dog confirmed injured; 3 wolves removed by WS

History: The Black Canyon pack (4 wolves) was first confirmed in 2004.

2005 Activities: Although it was first documented in 2004, little information was known about the Black Canyon pack. In January 2005, a pup born in 2004 was incidentally killed in a coyote snare in Horse Prairie. At the end of 2005, the pack did not have a radio collar despite the combined efforts of WS and MFWP to place a collar in this pack over 5 unsuccessful trapping sessions. These trapping efforts were often conducted in response to multiple depredation incidents that occurred between February and October 2005. A total of 3 yearling heifers and 6 sheep were confirmed killed. A heifer, a colt and a domestic dog were confirmed injured. In October, WS removed an adult male, an adult breeding female, and a male pup in the Big Hole Valley that were believed to be part of the Black Canyon pack, as the Battlefield pack was located farther north. At the end of 2005, 4 wolves were believed to remain in the Black Canyon pack. At least one pup was produced and confirmed by project personnel in June.

\section{Painted Rocks}

- at least 4 wolves; breeding pair

- no depredations reported

History: Wolf activity was first documented in the Painted Rocks area (West Fork of the Bitterroot River near the Montana-Idaho border) with the dispersal of Idaho female B67 in 2001. B67 was monitored through 2002,and the pack has not been collared since. At least four wolves have been in the area continuously and appeared to spend the majority of their time on the Montana side of the border.

2005 Activities: Six wolves were thought to be in the Painted Rocks pack at the beginning of 2005. Thanks to a reliable sighting from the public, MFWP personnel found a rendezvous site in September. We confirmed that at least two pups were produced in 2005 based on 
evidence found at this rendezvous site. MFWP initiated 2 different trapping sessions, but no wolves were caught. December snow tracking efforts confirmed a minimum of 4 wolves at the end of 2005.

$\underline{B i g \text { Hole }}$

- 9 wolves; breeding pair

- no depredations reported

History: The Big Hole pack formed in 1997 by two wolves (B7 and B11) that were first released in 1995 as part of the original reintroduction efforts. B7 and B11 were translocated out of the Big Hole Valley, Montana twice in 1996 and 1997 before settling and establishing a territory near Lolo Pass, west of Missoula. The Big Hole pack has had a continuous tenure in its home range since 1997.

2005 Activities: Because they denned and spent most of their time in Montana, the Big Hole pack was officially counted as a Montana pack in 2005. However, all field work was conducted by NPT personnel out of Idaho in coordination with MFWP. Monitoring flights were conducted by both the NPT and MFWP. Original alphas, B7 and B11, founders of this pack and members of the initial reintroduction in 1995, were both observed in 2005. However, their social status within the pack was unknown. Each of these wolves is now at least 10 years old and likely nearer to 12 years old. The pack produced a minimum of 2 pups in 2005, based on howling surveys. The estimated pack size at the end of 2005 was a minimum of 9 wolves based on field observations. The sole radio-collared wolf remained with the pack.

\section{Sapphire}

- 14 wolves; breeding pair

- no depredations reported

History: Wolf activity was first documented in the remote areas of the East Fork of the Bitterroot River and the east side of the Sapphire Mountains in 2001.

2005 Activities: In January 2005, 8 wolves (5 adults, 3 pups) were estimated in this pack. Wolf reports were received intermittently, though from consistent areas through most of the spring, summer and early fall. MFWP placed the first radio-collar in this pack in early October 2005. Monitoring was ongoing to determine the full extent of this pack's territory. Fourteen wolves (13 black and 1 gray) were seen from the air in early 2006, at least 4 of which are pups.

$\underline{\text { Sula }}$

- 7 wolves; breeding pair

- no depredations reported

History: New pack in 2005. Because a yearling wolf was caught in the April 2005, this pack likely existed and had pups in 2004 but was not documented until 2005. 
2005 Activities: A MFWP biologist was surveying elk from a fixed wing in April 2005 when he spotted 5 wolves (4 black, 1 gray) just west of Sula at the south end of the Bitterroot Valley. MFWP personnel started trapping in the area soon thereafter and caught two wolves, a black yearling female and a gray adult male. In mid-July, a hiker reported seeing a collared wolf in poor condition. The female wolf was found dead during the next monitoring flight, and her cause of death remained unknown because of advanced decomposition. Ten wolves (5 adults, 5 pups) were counted by MFWP personnel in this pack in mid-summer (3 gray and 7 black). By the end of 2005, only 7 wolves were observed, at least 2 of which were adults and 2 of which were pups.

\section{Skalkaho}

- 6 wolves; not a breeding pair

- no depredations reported

History: New pack in 2005. Wolf activity was reported east of Hamilton in 2004. WS and USFWS each attempted to place a collar in this pack that summer, but efforts were unsuccessful. However, at that time, it was unclear whether Skalkaho and Sapphire were the same pack.

2005 Activities: Throughout 2005, MFWP received numerous reports of wolves from a large area ranging from the East Fork of the Bitterroot to as far north as the Calf Creek Wildlife Management Area east of Hamilton. Most reports were of gray animals, although several were of a single black. Because of the large extent of the area, it's possible that 2 different packs were using the area but only 1 was confirmed by the end of the year. In April and May, MFWP initiated trapping efforts and caught 1 gray wolf. Unfortunately, it pulled out of the trap before it could be anesthetized. Wolves were seen on numerous occasions in the Sleeping Child drainage during hunting season. In December, a MFWP biologist saw 6 gray wolves in the foothills east of Hamilton from a fixed wing plane. No information on reproduction was obtained during 2005.

\section{$\underline{\text { Lake Como }}$}

- $\quad$ at least 3 wolves; not a breeding pair

- no depredations reported

History: This pack first produced pups and was documented as a breeding pair with 5 members at the end of 2002. Since then, very little was known about wolf activity in this area until 2005.

2005 Activities: Throughout 2005, MFWP received numerous reports in the Tin Cup, Spoon Creek, and Rock Creek/Lake Como areas. In the fall, a U.S. Forest Service biologist verified tracks of 3 wolves and saw 1 black wolf. No information on reproduction was obtained during 2005.

\section{Brooks Creek}

- 4 wolves; not a breeding pair

- no depredations reported 
History: New pack in 2005. The Bass Creek pack first established in this area in 1998. After repeated conflicts with livestock on private property, the entire pack was translocated to the Spotted Bear area of the South Fork of the Flathead River and established the Spotted Bear pack (see northwest Montana pack summaries above). No wolves were thought to have recolonized the Bass Creek area until 2005.

2005 Activities: After numerous reports of wolves on and near private property, project personnel initiated trapping efforts in April. An adult male was caught and radio-collared. The Brooks Creek pack localized during denning season, but no pups were ever seen or confirmed. Four adult wolves have been seen in the pack since then. Its home range appeared to slightly overlap the Montana-Idaho border, so it was considered a border pack.

\section{Willow Creek}

- 6 wolves; breeding pair

- no depredations reported

History: The Willow pack was first confirmed between Drummond and Phillipsburg in 2002. 2005 Activities: In early 2005, 2 wolves still appeared to be using the area but it was unknown whether they were related to the original Willow pack of 2002. In July, Alice Whitelaw and her dog Tsavo (Working Dogs for Conservation, Bozeman) found fresh wolf sign in the area historically used by this pack. MFWP personnel caught an adult male wolf. This wolf was originally collared in the Buffalo Ridge pack in Idaho in January 2003 and disappeared from its natal pack at the end of 2003. Its whereabouts were unknown until it was captured in the Willow territory. At the end of 2005, 6 wolves were seen (2 adults and 4 pups).

\section{Mt. Haggin}

- at least 2 wolves; not a breeding pair

- no depredations reported

History: The Mt. Haggin pack, south of Butte, was first documented as a group of three of wolves in 2001. Intermittent reports of wolves and wolf sign have been submitted each year since 2001.

2005 Activities: MFWP personnel were able to follow up on reports from the public in the Fleecer Mountain area and confirmed that at least 2 wolves were present in September 2005. Trapping was not initiated at the time due to excessive human activity in the area during archery season. A volunteer spent a week in the area in October scouting but did not turn up any more fresh sign. Several other sightings came in during the hunting season, suggesting that this may be a larger pack. However, additional wolves were not verified by project personnel. 


\section{Miscellaneous / Lone Individuals}

A single black wolf was first reported in the Hall, Montana area in the spring of 2005. In late March, a calf died and was considered a probable wolf kill. On May 23, a black uncollared female wolf was shot under the 10(j) regulations when she was discovered harassing cattle on private property. This wolf was believed to be the same wolf seen earlier in the spring.

On May 27, a disperser from the Morgan Creek pack in Idaho (B228M) was shot under the 10(j) regulations when he was discovered chasing cattle on private property in the Big Hole Valley.

\section{Suspected Packs}

Grassy Top: In 2005, there were only a few scattered reports of wolves in the Big Sheep Creek/Grassy Top area south of Dillon, Montana. The most reported together were 2 wolves. IDFG personnel received a number of reports of wolf activity around the Leadore, Idaho area to the south and west. We believed that these might be the same wolves seen on the Montana side. The total number of reports from both sides of the state border was small, and we were still not able to verify the existence of a pack on either side. However, because fewer reports were gathered on the Montana side, it appeared that if wolves had settled in the area, it would be considered an Idaho pack.

\section{Other Miscellaneous Information}

In mid-October, a rancher in the Hall area reported that 2 black wolves killed a deer close to their ranch. Later in the winter Bart Smith (WS) found fresh tracks of 2 wolves in this area when the Willow pack was known to have been in the Upper Willow Creek drainage for several days. No black wolves were known to be in the Willow pack. This area will be surveyed in 2006.

\section{OUTREACH AND EDUCATION}

MFWP had an extensive outreach and education program on wolves and the state program in 2005. Outreach activities take a variety of forms and include: meeting people in the field, visiting landowners on their ranches, phone conversations and email to share information and answer questions, and granting interviews with the media, writers, and others. MFWP wolf staff also gave presentations at organized functions. MFWP also prepared and distributed a variety of printed outreach materials and media releases to help Montanans become more familiar with the Montana wolf population, the state's plan, and the current federal regulations. During the course of the year, MFWP staff note their formal efforts in the USFWS Wolf Weekly report. However, the vast majority of public contacts made by the MFWP wolf staff and others in MFWP on a day-to-day basis throughout 2005 were not reflected in the USFWS Wolf Weekly report.

Other MFWP staff and volunteers were instrumental in accomplishing MFWP's outreach efforts. These included area game wardens, area wildlife biologists, block management personnel, information officers and front desk staff, staff of the Education Bureau, State Parks employees, 
the Helena staff (who work closely with the MFWP Commission, the legislature, and a variety of other elected or appointed officials), hunter education instructors, etc.

An important specific initiative in 2005 was the redesign of the wolf pages on the MFWP website. The pages were updated with new information on a variety of subjects with respect to wolf conservation and management in Montana. In January of 2006 alone, there were 1,200 visits to the wolf pages. In the fall, MFWP launched an application for hunters and other recreationists to report wolves and wolf activity through the website. Wolf reports helped MFWP monitor existing packs and document wolf activity in new areas leading to the verification of new packs. About 200 reports were received from late October to December 2005 alone. See www.fwp.mt.gov/wildthings/wolf.

A wide variety of media requests were received, ranging from daily newspapers, magazines, documentary filmmakers, to authors. Additionally, the MFWP website receives email comments and questions from a wide variety of interested publics. Efforts were made provide a timely response to as many as possible.

MFWP wolf staff gave at least one presentation at an organized function every week. A minimum of 79 presentations was given in 2005, reaching at least 2,129 people. When broken down by category, the majority of presentations were made to other agency/government professionals and livestock interests. However, no single group or setting dominated our efforts.

\section{Outreach Categories:}

- Civic: Kiwanis Club, Rotary Club, Lions Club, etc.

- Teacher/school: K-12 and teachers

- College/Professional: colleges and adult education

- Hunting: hunting, outfitting, road and gun, etc.

- Livestock: livestock groups, permittees, etc.

- Agency/government: Forest Service, BLM, NPS, county, etc.

- Conferences: Wildlife Society, Chico, IWC, etc.

- Other: all other

\begin{tabular}{lll} 
Outreach Categories & \# of Programs & Number of public \\
Civic & $4(5 \%)$ & $85(4 \%)$ \\
Teacher/school & $8(10 \%)$ & $307+(14 \%)$ \\
College/professional & $8(10 \%)$ & $210(10 \%)$ \\
Hunting & $7(9 \%)$ & $200+++(9 \%)$ \\
Livestock & $15(19 \%)$ & $262+++(12 \%)$ \\
Agency/government & $17(21 \%)$ & $235++++(11 \%)$ \\
Conferences & $9(11 \%)$ & $400++(19 \%)$ \\
Other & $11(14 \%)$ & $430+(20 \%)$ \\
& & \\
\hline Total: & 79 & 2,129
\end{tabular}

+ indicates an event that did not specify numbers. For instance in Agency/government, there were four more events where numbers were not noted. 


\section{RESEARCH AND OTHER FIELD STUDIES}

\section{Effects of Wolves, Hunters, and Human Access on Elk Spatial Dynamics}

Investigators: Jamin Grigg and Robert Garrott (Department of Ecology, Montana State University, Bozeman MT 59717, Ken Hamlin, Craig Jourdonnais, Mike Ross (Montana Fish Wildlife \& Parks, 1400 S. $19^{\text {th }}$, Bozeman MT 59715)

Collaborators: Montana State University, Montana Fish Wildlife \& Parks, Montana Department of Livestock, Denver Zoological Foundation, and numerous landowners in the Madison Valley, MT.

This project focuses on measuring differing behavioral patterns of elk when exposed to various types and levels of risk, particularly wolf predation pressure and human hunting pressure.

Building upon previous graduate research in the Madison Valley of southwestern Montana, we are placing 50 GPS collars and 17 VHF collars on adult, female elk on winter range over a two year period. Coupled with the resource of at least 1 GPS collar and 2 VHF collars on the resident Wedge wolf pack, we are studying how elk on this winter range behaviorally respond to the various risks of wolf predation and late-season hunting. We will also be documenting offtake by wolves and hunters and measuring functional equivalency of these two types of predators. A second focus of this research involves evaluating the impacts of roads, trails and hunting seasons on elk summer and fall distribution and timing of migration. By assessing how elk respond to predation pressure by both wolves and human hunters, and how climatic conditions and varying levels of human use of the landscape factor in, we build upon four years of previous research conducted on the wildlife dynamics of the Madison Valley and compliment ongoing research in two nearby sister study sites.

Deployed GPS collars are scheduled to blow off after approximately one year, at which point they will be retrieved and stored locations will be downloaded and analyzed. Locations stored at 30-minute (elk) and 3-hour (wolf) intervals on the GPS collars, combined with locations obtained through intensive daily ground telemetry monitoring of GPS and VHF collars, will enable analyses of both fine and broad-scale spatial distribution of wolves and elk on multiple temporal scales. By intensively researching elk responses to various types and levels of risk, we can address questions regarding how differing threats influence elk behavior. Data collection should be completed in winter 2006.

References:

Grigg, J. and Garrot, R . Lower Madison valley wolf/ungulate research project, 2004/2005 annual report. 
Responses of elk to wolves- behavior, nutrition, and demography.

Investigators: Scott Creel, David Christianson (Department of Ecology, Montana State University, Bozeman, MT 59717), Ken Hamlin, Craig Jourdonnais, Mike Ross (Montana Fish Wildlife \& Parks, 1400 S. $19^{\text {th }}$, Bozeman MT 59715)

This project continued a six-winter study of elk responses to wolves in the Gallatin Canyon, Montana. In this area, elk population size and calf:cow ratios have been depressed since recolonization by wolves in a manner that is not fully explained by direct predation alone. This project measured behavioral responses of elk to wolves and is measuring the affects of these responses for nutrition, survival, and reproduction of elk. Elk behavior was strongly dependent on temporal and spatial variation in wolf activity. Behavioral responses included changes in activity budgets, herd size and habitat selection. These responses were different between sexes, possibly because of differing nutritional constraints facing male and female elk in winter. These behavioral responses strongly suggest that winter foraging is influenced by wolf activity. The project continues to investigate changes in foraging strategies, diet selection, diet quality, nutrient balances, and body condition in winter as wolf predation risk varies, while monitoring changes in elk recruitment, demography, and population size. Data collection should be completed in winter 2006.

Recent project publications:

Christianson D \& Creel S (in press) A review of environmental factors affecting winter elk diets. Journal of Wildlife Management.

Creel S, Winnie JA, Maxwell B, Hamlin K \& Creel M 2005. Elk alter habitat selection as an antipredator response to wolves. Ecology 86:3387-3397.

Creel S \& Winnie J 2005. Responses of elk herd size to fine-scale spatial and temporal variation in the risk of predation by wolves. Animal Behaviour 69:1181-1189.

Relative contributions of habitat complexity and prey physical condition to predation by cougars and recolonizing wolves

Investigators: Todd C. Atwood ${ }^{1}$, Eric M. Gese ${ }^{2}$, and Kyran E. Kunkel ${ }^{1}$

${ }^{1}$ Department of Forest, Range, and Wildlife Sciences, Utah State University, Logan, UT 84322;

${ }^{2}$ USDA/APHIS/WS/National Wildlife Research Center, Department of Forest, Range, and Wildlife Sciences, Utah State University, Logan, UT 84322

Summary: When a recolonizing predator enters an already complex predator-prey system, specific antipredator behaviors may conflict and avoidance of one predator may enhance vulnerability to another. We studied the patterns of prey selection by recolonizing wolves (Canis lupus) and cougars (Puma concolor) in response to prey habitat shifts in the northern Madison Range, Montana. Elk (Cervus elaphus) were the primary prey for wolves and mule deer (Odocoileus hemionus) were the primary prey for cougars, but elk made up an increasingly 
greater proportion of cougar kills annually. While both predators preyed disproportionately on bull elk, wolves were most likely to prey on bulls in poor physical condition. Although we found that the predators partitioned hunting habitats, structural complexity at wolf kill sites increased over time, whereas complexity of cougar kill sites remained static. We concluded that habitat shifts in prey were attempts by formerly naïve prey to lessen predation risk from wolves. However, shifting to more structurally complex habitats might have made prey more vulnerable to cougars. Habitat shifts may represent a compromise to minimize overall risk, following a change in predator exposure.

\section{The effects of recolonizing wolves on coyote scavenging}

Investigators: Todd C. Atwood ${ }^{1}$ and Eric M. Gese ${ }^{2 .}$

${ }^{1}$ Department of Forest, Range, and Wildlife Sciences, Utah State University, Logan, UT 84322;

${ }^{2}$ USDA/APHIS/WS/National Wildlife Research Center, Department of Forest, Range, and Wildlife Sciences, Utah State University, Logan, UT, USA, 84322

Summary: Wolf recolonization of the Greater Yellowstone Ecosystem provides a rare opportunity to identify nascent behaviors facilitating coexistence between sympatric canids. Accordingly, we investigated behavioral interactions between putatively naïve coyotes (Canis latrans) and recolonizing wolves (Canis lupus) at ungulate carcasses in Montana's Madison range. We employed a quasi-experimental study design consisting of a 3-level carcass treatment (actual wolf presence, wolf presence simulated, wolf absence) to assess factors influencing coyote risk assessment, carrion consumption, and aggressive encounters with wolves. Socially dominant coyotes (alphas and betas) responded to actual and simulated wolf presence by increasing the proportion of time spent vigilant while scavenging. Vigilance behavior was more pronounced when scavenging closer to protective cover, where lateral occlusion inhibited the ability of coyotes to scan for, and possibly escape from, returning wolves. Despite greater time spent vigilant, alpha coyotes consumed the greatest amount of carrion biomass. This was accomplished by feeding on carcasses in earlier stages of consumption when organs and large muscle tissues were still present. This suggests that alpha coyotes might trade-off greater risk for higher quality food items. Coyotes would aggressively confront wolves, and numeric superiority and the stage of carcass consumption were influential in determining whether coyotes were able to displace wolves from carcasses. Coyotes rely on a gradient of risk-sensitive behaviors, ranging from elevated vigilance to aggressive confrontation, to manage risk associated with wolf presence. Identification of these behaviors, and their sensitivity to numeric and social factors, is an important step in elucidating mechanisms of sympatry in social canids.

\section{Range Rider Projects and their Effectiveness in southwest Montana}

Collaborators: Montana Fish Wildlife \& Parks, Madison Valley Ranchlands Group, Boulder Watershed Association, individual livestock producers, Turner Endangered Species Fund, USDA Forest Service, Predator Conservation Alliance, the Sun Ranch, USDA Wildlife Services, USDA 
Natural Resources and Conservation Service, Sweet Grass County Conservation District, and MSU Extension Service.

The Range Riders Project is a collaborative effort between ranchers, government agencies, and conservationists. The primary goal of these efforts is to reduce livestock/predator interactions. Secondary goals and objectives are to reduce livestock depredation from predators, to detect injured or dead livestock more rapidly, to preserve the evidence and increase the likelihood that an investigation would yield a definitive conclusion about whether or not it was a predation event and the species responsible, to improve livestock management and range conditions, to increase knowledge about livestock/predator interactions in space and time, and to build relationships among project partners. All project collaborators provided funding and in-kind contributions. In particular, significant funding was provided through the Natural Resources and Conservation Service’s Environmental Quality Incentives Program.

Range Rider projects were implemented in both 2004 and 2005 on a combination of public grazing allotments and private lands in a variety of settings in the Madison Valley south of Ennis and in the Boulder River Valley south of Big Timber. Although the rider protocols varied from place to place, the underlying premise is similar: increased and continual human presence and immediate response to wolves that are interacting with livestock. The rider response towards wolves when they are interacting with livestock ranges from non-lethal harassment to a lethal bullet. By responding as closely as possible in space and time to the inappropriate behavior (e.g., chasing livestock), the wolves are more likely to associate that behavior with something negative than if they had not been harassed while behaving inappropriately.

Even though the rider(s) are out day and night, cattle on public grazing allotments and in some circumstances on private lands are dispersed across a wide area. Livestock may also be in rugged, partially forested terrain. Nonetheless, use of horses and vehicles (where applicable) allows the rider to cover as much ground as possible while checking on livestock. There is still a good chance they will not be in exactly the right location at the exactly the right time to respond to the wolves. However, the chances of preventing a depredation are expected to be better than when/where human presence is more limited or infrequent.

Due to the incredible number of variables from place to place, there is no clear evidence that these efforts have actually prevented depredations. However, when surveyed, many participating producers said they thought it was helpful and indicated an interest in continuing their participation. Efforts to collect information to better understand the effectiveness of this technique will continue in 2006.

\section{$\underline{\text { A Pilot Study to Test Scat Detection Dogs to Monitor Gray Wolf Packs in Montana }}$}

Collaborators: Working Dogs for Conservation, Twin Spruce Foundation, Montana Fish, Wildlife and Parks, U.S. Fish and Wildlife Service, Turner Endangered Species Fund and Denver Zoological Foundation.

Alice R. Whitelaw, Working Dogs for Conservation, 140 Schutz Lane, Bozeman, MT 59718 
Liz H. Bradley, Montana Fish, Wildlife and Parks, Dillon, MT

Val J. Asher, Turner Endangered Species Fund, 1123 Research Drive, Bozeman, MT 59718

This project focused on obtaining preliminary information on the potential value of using scat detection dogs to monitor wolf populations in Montana. Particularly, to determine whether scat detection dogs can identify presence/absence of wolf activity in a given area and if they could assist in narrowing down areas of recent wolf activity to enhance trapping and collaring efforts (Whitelaw et al. 2006).

Domestic canines have a long history of locating wildlife and their sign. Aside from hunting applications, dogs have been used to assist in conservation efforts for decades by locating the species of interest or their sign such as hair, urine, nests and dens and feces.

Two veteran detection dogs (Dog 1) a 8 year old German Shepherd female and (Dog 2) a 5 year old German shepherd male were trained to detect wolf scat. Of the two, Dog 2 was deployed in 2 areas in western Montana where wolf presence had been verified but where radio-collars had not yet been used to monitor the packs. Roads and trails were surveyed in each area. All transects were searched with the dog off-leash to maximize the area covered. At the time of collection, the location of each scat was recorded using a hand held GPS unit. Additional locations of wolf sign (tracks, kill sites) were also recorded. We noted habitat type, and whether the sample was found on a road, hiking or game trail or in vegetation.

We determined that specially trained detection dogs are effective in locating areas of recent wolf activity. MFWP successfully captured and radio collared a wolf in an area surveyed by Dog 2 and where the detection dog had indicated recent activity. Dog 2 often indicated scats (and in one instance an apparent old wolf kill) in vegetation while experienced wolf biologists missed these signs while surveying.

\section{Literature Cited}

Whitelaw, Alice R., L. H. Bradley, V. J. Asher. February 2006. : A Pilot Study to Test Scat Detection Dogs to Monitor Gray Wolf Packs in Montana. Results and progress report, 2006.

\section{LAW ENFORCEMENT}

The USFWS Office of Law Enforcement remained the lead agency investigating wolf deaths in Montana. The number of investigations increased this year mainly due to the investigations of wolves killed for harassing livestock under the 10(j) regulations. To date, no evidence of illegal action has been found during the investigation of wolves killed for harassing of livestock. The State of Montana has laws that protect wolves and the state wardens work closely with the USFWS in all enforcement cases. 


\section{FUNDING}

MFWP's core wolf program is funded through 2 separate federal sources. Approximately half is obtained through a direct annual Congressional appropriation and half is obtained directly from USFWS. These sources are identified in the state-federal wolf cooperative agreement and are transferred on a federal fiscal year cycle. Federal funds can be spent anywhere in Montana for the wolf management and conservation activities specified in the cooperative agreement. Although the agreement states that a total of $\$ 637,000$ is to be available to Montana annually, federal budget constraints have resulted in Congressional recessions (across the board percentage cuts). Therefore, Montana received about $\$ 607,000$ in federal fiscal year 2005. Montana may renegotiate the responsibilities identified in the agreement in the future if adequate federal funds are not available and Montana is unable to fulfill the responsibilities described in the agreement.

Montana allocated its wolf budget in ways typical of any other wildlife conservation and management program. The vast majority of dollars were allocated to population monitoring. Funds were also allocated to support: the MFWP Wildlife Research Lab in Bozeman, MFWP law enforcement assistance, outreach and information / education activities, miscellaneous field equipment, research, increased ungulate monitoring, and additional step-down planning and program development. In-kind contributions and investments were made by the many private citizens who supported or were affected by the success of wolf recovery, by interested nongovernmental organizations, and other state and federal agencies.

Montana USDA WS was funded through the regular Congressional budgeting process for federal agencies. In federal fiscal year 2005, WS spent an estimated \$152,179 investigating wolf complaints and carrying out lethal control activities.

In 2004, Montana coordinated the efforts of Idaho and Wyoming to prepare a tri-state Congressional budget request. MFWP's director presented it to the Congressional Sportsmen's Caucus in fall 2004. The message presented was a celebration of recovery success, accompanied by the honest assessment that securing the investment into the future will require an ongoing national commitment to funding.

How well the nation's wolves and grizzly bears fare in the NRM depends on how well they are accepted by the people who live, work and recreate in these areas. The establishment of adequately funded conservation and management programs will determine the degree to which people will share the land, how well they will tolerate wolves and grizzly bears, and how successfully they will rise to the challenges posed by species recovery. Those challenges are shared by everyone, not just residents of the tri-state area.

\section{PERSONNEL AND ACKNOWLEDGEMENTS}

By now, literally hundreds of people have assisted with wolf recovery efforts in a wide variety of ways, and we are indebted to them all. Since 2000, countless more have assisted with the development of the Montana wolf plan and many more continue to assist during the transition 
from federal management to state management. We especially want to acknowledge the support and understanding from our families and friends.

The MFWP wolf team is comprised of Kent Laudon in Kalispell, Carolyn Sime in Helena, Mike Ross and Val Asher in Bozeman, Liz Bradley in Dillon, and Jon Trapp in Red Lodge. But the wolf team is part of a much bigger team of tremendously dedicated agency professionals that make up Montana Fish, Wildlife \& Parks. Wolf work is also supported by and carried out by others throughout the agency. We thank Adam Messer of MFWP Information Services for his patience, good humor, and expertise in creating the maps for this report, his work on all our other wolf project data requests, and for his help with data management. Regional biologists and game wardens, information officers, front desk staff, and program managers contribute their time and expertise in a variety of ways and have been invaluable in helping the wolf program get off to a solid start. We appreciate the MFWP Helena staff from all the Divisions who contributed their expertise and time; they also provided support and a steady hand while helping us get a variety of program activities underway during this first year -- right down to finding vehicles, cell phones, computers, uniforms and field equipment. We thank Caryn Amacher, Denise Dawson, Donna Campbell, Rebecca Cooper, Adam Brooks for assisting us with interagency cooperative agreements, grant agreements, and budgeting. We appreciate the wise counsel and participation of the MFWP legal staff, especially Bob Lane and Martha Williams. We appreciate the work and dedication of the MFWP Website Team of Beth Stephenson and Ira Miller who created the on-line wolf public reporting system and cheerfully revamped the wolf web pages amidst volumes of other work. Jay Lightbody and Don Bartsch at the Print shop prepared and printed outreach materials. We thank the staff of the Communications and Education Division for their thoughtful reviews of our work and for their media contributions throughout the year. The Montana Governor's Office, MFWP Director's Office, and the MFWP Commission deserve special recognition for their strong commitment to move forward despite the delisting delay; they provided important leadership and steady guidance.

The Montana wolf management program also benefited from the volunteer contributions of Jonathan Durbridge and Mischa Connine, who were very dedicated to the job and worked almost literally non-stop. Tyler Hollow spent many days afield scouting out pubic wolf reports and ground tracked the Halfway and Spotted Dog packs outside of Helena. Janeen Hetzler, Nathan Stone, Erin Fairbank, Kristina Davis, and Stephanie Naftal assisted with scouting and trapping efforts in southwest Montana. Allie Hunter assisted with public sighting data entry. MSU graduate students Jamin Grigg and Dave Christianson and technicians Stewart Lilly and Julee Shamhart put in long hours in the field in southwest Montana. Amy Edmonds, Glacier National Park, conducted ground monitoring for the Kintla and Whitefish Packs. Salish Kootenai Confederated Tribes biologist Stacey Courville and Blackfeet Tribe biologist Dan Carney monitored wolves in and around their respective tribal reservations.

USFWS personnel in Montana included wolf recovery coordinator Ed Bangs (Helena) who shepherded the development of the state-federal cooperative agreement and freely shared information and data about wolves in Montana. We are especially grateful for the financial support and his confidence in the developing state program. Law enforcement agents Rick Branzell (Special Agent, Missoula) and Doug Goessman (Special Agent, Bozeman) investigated wolf mortalities throughout Montana and provided important guidance about the federal 
regulations. Dominic Dominici (USFWS Agent in Charge, WY) provided valuable guidance and information about a variety of subjects and the interpretation of federal regulations. By year's end, Joe Fontaine (Helena) had accepted a new position managing a national wildlife refuge in Mississippi. We are especially grateful to him for all the experience and knowledge he shared, the information he was able to retrieve off the top of his head at a moment's notice, and his support, good humor, and encouragement as we took the reins. We wish him well.

WS investigates suspected wolf damage and carries out wolf control activities in Montana. We thank them for contributing their expertise to the Montana wolf program and for their willingness to complete investigations in a timely fashion, 7 days a week. WS personnel involved in wolf management in Montana in 2005 included state director Larry Handegard, eastern district supervisor Paul J. Hoover, western district supervisor Kraig Glazier, wildlife specialists Dennis Biggs, John Bouchard, Steve Demers, Michael Hoggan, Dan Thomason, Alan Brown, Brian Noftsker, Mike Thomas, Chad Hoover, R.R. Martin, Graeme McDougal, Theodore North, James Rost, Pat Sinclair, John Maetzold, Paul Bucklin, Bart Smith, and James Stevens, and pilots Stan Colton, Tim Graff, Eric Waldorf, Jake Wimmer, and Larry Lundquist.

The Montana Wolf Management program field operations also benefited in a multitude of ways from the continued cooperation of other state and federal agencies and private interests such as The Blackfeet Tribal Wildlife Program, USDA Forest Service, Montana Department of Natural Resources and Conservation (“State Lands”), U.S. Bureau of Land Management, Plum Creek Timber Company, Glacier National Park, Yellowstone National Park, Idaho Fish and Game, Montana Department of Natural Resources and Conservation, Canadian Provincial wildlife professionals, Defenders of Wildlife, Predator Conservation Alliance, Boulder Watershed Group, and the Madison Valley Ranchlands Group.

We deeply appreciate and thank our pilots whose unique and specialized skills, help us find wolves, get counts, and keep us safe in highly challenging, low altitude mountain flying. They include David Hoerner (Red Eagle Aviation, Kalispell), Steve Davidson (Selway Aviation, Hamilton), Doug Chapman (Montana Aircraft, Bozeman), Roger Stradley (Gallatin Flying Service, Belgrade), Steve Ard (Tracker Aviation Inc., Belgrade), Mark Duffy (Bozeman).

The citizens of Montana deserve special recognition for their cautious willingness to craft a balanced plan that recognizes that wolves are a native species now back on the landscape where people live, work and recreate, to accept the responsibility for wolf conservation and management, and their willingness to move forward knowing that it will continue to be controversial, challenging, and that hard decisions have to be made. We also appreciate the time they take to send us wolf report postcards, on-line wolf reports, or to call us on the phone with their information. The individuals who served on the original Montana Wolf Management Advisory Council and the Wolf Compensation Working Group continue to serve Montana informally by sharing their perspectives and being a source of information in their respective communities.

And lastly, the countless private landowners in Montana whose property is used by wolves, sometimes at great cost to the owner, deserve our respect, our understanding and attention to their new challenges, and our gratitude. 


\section{NORTHERN ROCKY MOUNTAIN WOLF BIBLIOGRAPHY：1999-2005}

Akenson, J., H. Akenson, and H. Quigley. 2005. Effects of wolf reintroduction on a cougar population in the central Idaho wilderness. Mountain lion workshop 8:177-187.

Almberg, E., R. McIntyre, D.R. Stahler, D.W. Smith, B. Chan, M. Ross, J. Knuth Folts, D. Chalfant, B Suderman. 2004. Managing wolves and humans in Lamar Valley. Final Report on Druid Road Management Project 2004. YNP Report. 9 pp.

Arjo, W.M., D.H. Pletscher, and R.R. Ream, 2002. Dietary overlap between wolves and coyotes in northwestern Montana. Journal of Mammalogy 83(3): 754-766.

Asher, V., J.A. Shivik, K. Kunkel, M. Phillips, and E. Bangs. 2001. Evaluation of electronic aversive conditioning for managing wolf predation. Proceedings of the International Theriological Congress People and Predators Conference, South Africa.

Ballard, W.B., D. Lutz, T.W. Keegan, L.H. Carpenter, and J.C. Devos Jr. 2001. Deer-predator relationships: a review of recent North American studies with emphasis on mule and black-tailed deer. Wildlife Society Bulletin 29(1): 99-115.

Ballard, W.B., L.N. Carbyn, and D.W. Smith. 2003. Wolf interactions with non-prey. Pp. 259271 in Wolves: Behavior, Ecology, and Conservation (L. D. Mech and L. Boitani, eds.). University of Chicago Press, Chicago IL.

Bangs, E. 2000. Gray wolf restoration in the northwestern United States. Pages 39-45 in Predator Management in Montana: Symposium Proceedings. January 2000, Billings, MT. Conducted by Montana Outfitters and Guides Assoc. and Montana Fish, Wildlife and Parks.

Bangs, E. 2001. Wolf management by zoning. International Wolf 11(3): 21.

Bangs, E. 2002. Wolf predation and elk in the Greater Yellowstone Area. International Wolf. 12(4): 28.

Bangs, E. 2003. Wolves have reached recovery levels in the northern Rocky Mountains: How does delisting happen? International Wolf 13: 21-22.

Bangs, E.E. 2004. Book review of Mech, L.D. and L. Boitani [eds]. 2003. Wolves: Behavior, Ecology, and Conservation, University of Chicago Press. Journal of Mammalogy 85(4): 814-815.

Bangs, E., and J. Shivik. 2001. Managing wolf conflict with livestock in the northwestern United States. Carnivore Damage Prevention News No. 3: 2-5. 
Bangs, E.E., and D.W. Smith. 2006. "Ecological effects of wolves.” in 'Restoring the Pacific NW: the art and science of Ecological Restoration in Cascadia'. Island Press, Washington D.C. Available in May 06.

Bangs, E.E., B. Barbee, and R.O. Peterson. 2005. Perspectives on Wolf Restoration. Yellowstone Science 13(1): 4-6.

Bangs, E., J. Fontaine, M. Jimenez, T. Meier, C. Niemeyer, D. Smith, K. Murphy, D. Guernsey, L. Handegard, M. Collinge, R. Krischke, J. Shivik, C. Mack, I. Babcock, V. Asher, D. Domenici. 2001. Gray wolf restoration in the northwestern United States. Endangered Species Update 18(4): 147-152.

Bangs, E., M. Jimenez, C. Niemeyer, T. Meier, V. Asher, J. Fontaine, M. Collinge, L. Handegard, R. Krischke, D. Smith, and C. Mack. 2005. Livestock guarding dogs and wolves in the northern Rocky Mountains of the United States. Carnivore Damage Prevention News No. 8/January 2005: 32-39.

Bangs, E., J. Fontaine, T. Meier, C. Niemeyer, M. Jimenez, D. Smith, C. Mack, V. Asher, L. Handegard, M. Collinge, R. Krischke, C. Sime, S. Nadeau, and D. Moody. 2005. Restoration and conflict management of the gray wolf in Montana, Idaho, and Wyoming. Trans. N. American Wildlife and Natural Resources Conference Vol 69:89-105.

Bangs, E.E., J.A. Fontaine, M.D. Jimenez, T.J. Meier, E.H. Bradley, C.C. Niemeyer, D.W. Smith, C.M. Mack, V. Asher, J.K. Oakleaf. 2005. Managing wolf/human conflict in the northwestern United States. Pages 340-356, in R. Woodroffe, S. Thirgood, and A. Rabinowitz, eds. People and wildlife: coexistence or conflict? Cambridge University Press, Cambridge, United Kingdom.

Barber, S., L. D. Mech, and P. J. White. 2005. Yellowstone elk calf mortality following wolf restoration: bears remain top predator. Yellowstone Science 13(3):37-44.

Batastini, J.W. 2005. The impact of wolves on the "market" for elk hunting in Montana: hunter adjustment and game agency response. M.S. thesis. Montana State University, Bozeman, Montana.

Berger, J., 1999. Anthropogenic extinction of top carnivores and interspecific animal behavior: Implications of the rapid decoupling of a web involving wolves, bears, moose and ravens. Proc. Royal Society London B. 2261-2267.

Berger, J., P.B. Stacey, L. Bellis, and M.P. Johnson. 2001. A mammalian predator-prey imbalance: grizzly and wolf extinction affect avian neotropical migrants. Ecological Applications 11: 947-960. 
Berger, J. and D.W. Smith. 2005. Restoring functionality in Yellowstone with recovering carnivores: Gains and uncertainties. Pgs. 100-109 in Large carnivores and biodiversity conservation. Editors, J.C. Ray, K.H. Redford, R.S. Steneck and J. Berger. Island Press, Washington D.C.

Bergman, E.J., 2003. Assessment of prey vulnerability through analysis of wolf movements and kill sites. M.S. thesis, Montana State University, Bozeman, Montana. (submitted to Ecological Applications).

Beschta, R.L. 2003. Cottonwoods, elk, and wolves in the Lamar Valley of Yellowstone National Park. Ecological Applications 13: 1295-1309.

Bishop, N.A. and D.W. Smith. 2003. The survivors. International Wolf 13(1): 4-7.

Boyd, D.K., and D.H. Pletscher. 1999. Characteristics of dispersal in a colonizing wolf population in the central Rocky Mountains. Journal of Wildlife Management 63:10941108.

Boyd, D.K., S.H. Forbes, D.H. Pletscher, and F.W. Allendorf. 2001. Identification of Rocky Mountain gray wolves. Wildlife Society Bulletin 29(1): 78-85.

Bradley, E.H. 2004. An evaluation of wolf-livestock conflicts and management in the northwestern United States. M.S. thesis, University of Montana. Missoula, MT.

Bradley, E. H., D. H. Pletscher, E. E. Bangs, K. E. Kunkel, D. W. Smith, C. M. Mack, T.J. Meier, J. A. Fontaine, C. C. Niemeyer, and M. D. Jimenez. 2005. Evaluating wolf translocation as a non-lethal method to reduce livestock conflicts in the northwestern United States. Conservation Biology 19:1498-1508.

Bradley, E. H., and D. H. Pletscher. 2005. Assessing factors related to wolf depredation of cattle in fenced pastures in Montana and Idaho. Wildlife Society Bulletin 33(4):xxx-xxx.

Bradley, E. H., D. H. Pletscher, E. E. Bangs, K. E. Kunkel, D. W. Smith, C. M. Mack, J.A. Fontaine, C. C. Niemeyer, T. J. Meier, and M. D. Jimenez. In Prep. Effects of wolf removal on livestock depredation in Montana, Idaho, and Wyoming.

Brainerd, S.M., H. Andren, H., E.E. Bangs, E. Bradley, J. Fontaine, W. Hall, Y. Iliopoulos, M. Jiminez, E. Jozwiak, O. Liberg, C. Mack, T. Meier, C. Niemeyer, H.C. Pedersen, H. Sand, R. Schultz, D.W. Smith, P. Wabakken, A. Wydeven. In prep. The effects of alpha wolf (Canis lupus) loss on reproduction and pack dynamics.

Breck, S.W., R. Williamson, C. Niemeyer, and J.A. Shivik. 2002. Non-lethal radio activated guard for deterring wolf depredation in Idaho: summary and call for research. Proceedings of the Vertebrate Pest Conference 20: 223-226. 
Breck, S.W. and T. Meier. 2004. Managing wolf depredation in United States: past, present and future. Sheep and Goat Research Journal 9: 41-46.

Carroll, C., M.K. Phillips, N.H. Schumaker, and D.W. Smith. 2003. Impacts of landscape change on wolf restoration success: Planning a reintroduction program based on static and dynamic spatial models. Conservation Biology 17(2): 536-548.

Carroll, C., M.K. Phillips, C.A. Lopez-Gonzales, and N.H. Schumaker. 2006. Defining Recovery goals and Strategies for Endangered Species: The wolf as a case study. Bioscience 56:25-37.

Claar, J.J., N. Anderson, D. Boyd, M. Cherry, B. Conard, R. Hompesch, S. Miller, G. Olson, H. Ihsle Pac, J. Waller, T. Wittinger, and H. Youmans. 1999. Effects of recreation on Rocky Mountain carnivores. Pages 7.1- 7.63 in G. Joslin and H. Youmans, eds., Effects of recreation on Rocky Mountain wildlife: a review for Montana. Montana Chapter of The Wildlife Society. 307 pp.

Colorado Wolf Management Working Group. 2005. Findings and recommendations for managing wolves that migrate into Colorado. Colorado Division of Wildlife, Denver, CO. 67 pp. It's available on the web at: http://wildlife.state.co.us/NR/rdonlyres/619DF3FC-A0DE-4AB1-A6068334764466E2/0/recomendations.pdf

Cook, R. C., J. G. Cook, and L. D. Mech. 2004. Nutritional condition of Northern Yellowstone elk. Journal of Mammalogy 85(4):714-722.

Creel, S., J.E. Fox, A. Hardy, J. Sands, B. Garrott, and R.O. Peterson. 2002. Snowmobile activity and glucocorticoid stress responses in wolves and elk. Conservation Biology 13(3): 809-814.

Creel S., G. Spong, J.L. Sands, J. Rotella, J.L. Ziegle, K.M. Murphy, and D.W. Smith. 2004. Population size estimation in Yellowstone wolves with error-prone noninvasive microsatellite genotypes. Molecular Ecology 12: 2003-2009.

Creel S, Winnie JA, Maxwell B, Hamlin K \& Creel M. 2005. Elk alter habitat selection as an antipredator response to wolves. Ecology 86:3387-3397.

Creel, S., and J. Winnie J. 2005 Responses of elk herd size to fine-scale spatial and temporal variation in the risk of predation by wolves. Animal Behaviour 69: 1181-1189

Christianson D. and S. Creel S (in press) A review of environmental factors affecting winter elk diets. Journal of Wildlife Management.

Duncan, R., and A. Mahle. 2004. Wolves are still in need of federal protection. International Wolf 14(1): 5-7 
Eberhardt, L.L., R.A. Garrott, D.W. Smith, P.J. White, and R O. Peterson. 2003. Assessing the impact of wolves on ungulate prey. Ecological Applications 13(3): 776-783.

Evans, S., D.W. Smith and K. Murphy. 2000. Evaluation of wolf activity along the Tower to Canyon road in Yellowstone National Park, 1995-1999. YNP report, 17 pp.

Evans, S. B., L. D. Mech, D. W. Smith, P. J. White, and G. A. Sargeant. 2006. Survival and causes of mortality of cow elk in Yellowstone's northern range. Journal of Wildlife Management 70:000-000. [In Press].

Fascione, N., H. Ridgley, and M. Selden. 2000. Proceedings of Defenders of Wildlife's Carnivores 2000: A Conference on Carnivore Conservation in the $21^{\text {st }}$ Century. Defenders of Wildlife, Washington D.C. 208 pp.

Ferguson, G. and D.W. Smith. 2005. A decade of wolves in Yellowstone. Montana Magazine (May-June):16-22.

Fortin, D., H.L. Beyer, M.S. Boyce, D.W. Smith, T. Duchesne, J.S. Mao. 2005. Wolves influence elk movements: Behavior shapes a trophic cascade in Yellowstone National Park. Ecology 86:1320-1330.

Fritts. S.H. 2000. Review of Carnivores in Ecosystems: the Yellowstone Experience. Ecology 81(8): 2351-2352.

Fritts, S.H. 2000. A greater tolerance: coexistence of wolves and humans. International Wolf 10(1): 8-11.

Fritts, S.H., C.M. Mack, D.W. Smith, K.M. Murphy, M.K. Phillips, M.D. Jimenez, E.E. Bangs, J.A. Fontaine, C.C. Niemeyer, W.G. Brewster, and T.J. Kaminski. 2001. Outcomes of hard and soft releases of reintroduced wolves in Central Idaho and the Greater Yellowstone area. Pages 125-147 in Large Mammal Restoration: Ecological and Sociological Challenges in the $21^{\text {st }}$ Century, D.S. Maehr, R.F. Noss and J.L. Larkin, eds. Island Press, Washington, D.C.

Fritts, S.H., R.O. Stephenson, R.D. Hayes, and L. Boitani. 2003. Wolves and Humans. Pages 289-316 in L.D. Mech and L. Boitani, editors Wolves: Behavior, Ecology, and Conservation. University of Chicago Press. Illinois, USA.

Gipson, P.S., E.E. Bangs, T.N. Bailey, D.K. Boyd, H. D. Cluff, D.W. Smith, and M.D. Jimenez. 2002. Color patterns among wolves in western North America. Wildlife Society Bulletin 30(3): 821-830.

Gude, J. A. 2004. Applying risk allocation theory in a large mammal predator-prey system: elkwolf behavioral interactions. M.S. Thesis, Montana State University, Bozeman, MT USA. 
Gunther, K. A. and D. W. Smith. 2004. Interactions between wolves and female grizzly bears with cubs in Yellowstone National Park. Ursus 15(2): 232-238.

Hamlin, K. L. 2005. Monitoring and assessment of wolf-ungulate interactions and population trends within the Greater Yellowstone Area, Southwestern Montana, and Montana Statewide. Montana Fish, Wildlife \& Parks, Bozeman, MT. 50pp.

Hebblewhite, M., P.C. Paquet, D.H. Pletscher, R.B. Lessard, and C.J. Callaghan. 2003. Development and application of a ratio estimator to estimate wolf kill rates and variance in a multi-prey system. Wildlife Society Bulletin 31(4): 933-946.

Hebblewhite, M., D.H. Pletscher, and P. Paquet. 2003. Elk population dynamics following wolf recolonization of the Bow Valley of Banff National Park. Research Links 11(1):10-12.

Hebblewhite, M. and D. H. Pletscher. 2002. Effects of elk groups size on predation by wolves. Canadian Journal of Zoology 80:800-809.

Hebblewhite, M., D. H. Pletscher, P.C. Paquet. 2002. Elk population dynamics in areas with and without predation by recolonizing wolves in Banff National Park, Alberta. Canadian Journal of Zoology 80: 789-799.

Holland, J. S. 2004. The wolf effect. National Geographic, October.

Holyan, J., D. Boyd, C. Mack, and D. Pletscher. In Press. Longevity and productivity of three wolves, Canis lupus, in the wild. Canadian Field-Naturalist.

Husseman, J.S. 2002. Prey selection patterns of wolves and cougars in East-central Idaho. Unpublished thesis, University of Idaho, Moscow.

Husseman, J.S., D.L. Murray, G. Power, and C. Mack. 2003. Correlation patterns of marrow fat in Rocky Mountain elk bones. Journal of Wildlife Management 67(4): 742-746.

Husseman, J.S., D.L. Murray, G. Power, C. Mack, C.R. Wenger, and H. Quigley. 2003. Assessing differential prey selection patterns between two sympatric large carnivores. Oikos 101: 591-601.

Jaffe, R. 2001. Winter wolf predation in an elk-bison system in Yellowstone National Park, Wyoming. Unpublished M. S. thesis, Montana State University.

Jacobs, A.K. 2000. Leadership behavior in dominant breeding, subordinate breeding, and nonbreeding wolves (Canis lupus) in Yellowstone national Park, WY. Unpublished thesis. Science in Forestry. Houghton, MI, Michigan Technological University. 54pp.

Jimenez, M. D., and J. Stevenson. 2003. Wolf-elk interactions on state-managed feed grounds in Wyoming. 2002 progress report. USFWS, 190 N First St., Lander WY 82520. 11 pp. 
Jimenez, M. D., and J. Stevenson. 2004. Wolf-elk interactions on state-managed feed grounds in Wyoming. 2003 progress report. USFWS, PO Box 2645, Jackson, WY 83001. 13 pp

Jimenez, M.D., S.P. Woodruff, S. Cain, and S. Dewey. 2005. Wolf-elk interactions on winter range and state-managed feed grounds in Wyoming. 2005 progress report. USFWS, P.O. Box 2645, Jackson, WY 83001. 12 pp.

Kostel, K. 2004. Leftovers Again? Science News. March.

Kunkel, K.E., and D.H. Pletscher. 1999. Species-specific population dynamics of cervids in a multipredator ecosystem. Journal of Wildlife Management 63: 1082-1093.

Kunkel, K.E., T.K. Ruth, D.H. Pletscher, and M.G. Hornocker. 1999. Winter prey selection by wolves and cougars in and near Glacier National Park, Montana. Journal of Wildlife Management 63: 901-910.

Kunkel, K.E., and D.H. Pletscher. 2000. Habitat factors affecting vulnerability of moose to predation by wolves in southeastern British Columbia. Canadian Journal of Zoology 78: 150-157.

Kunkel, K.E., and D.H. Pletscher. 2001. Winter hunting patterns and success of wolves in Glacier National Park, Montana. Journal of Wildlife Management 65: 520-530.

Kunkel, K.E., D.H. Pletscher, D.K. Boyd, R.R. Ream, and M.W. Fairchild. 2004. Factors correlated with foraging behavior of wolves in and near Glacier National Park, Montana. Journal of Wildlife Management 68(1): 167-178.

Leonard, J.A., C. Vila, and R.R. Wayne. 2005. Legacy lost: genetic variability and population size of extirpated U.S. Grey Wolves (Canis lupus). Molecular Ecology 14:9-17.

Mack, C., and K. Laudon. 1999. Idaho wolf recovery program: Restoration and management of gray wolves in central Idaho. Progress Report 1995-1998. Nez Perce Tribe, Department of Wildlife Management, Lapwai, ID. 22 pages.

Mack, C.M., I. Babcock, and J. Holyan. 2002. Idaho Wolf Recovery Program: Restoration and management of gray wolves in Idaho. Progress report 1999-2001. Nez Perce Tribe, Department of Wildlife Management, Lapwai, ID. 34 pp.

Mack, C.M., and J. Holyan. 2003. Idaho wolf recovery program: Restoration and management of gray wolves in central Idaho. Progress report 2002. Nez Perce Tribe, Department of Wildlife Management, Lapwai, ID. 34 pp.

McIntyre, R., and D. W. Smith. 2000. The death of a queen: Yellowstone mutiny ends tyrannical rule over Druid Pack. International Wolf 10(4): 8-11. 
McNay, M.E. 2002. Wolf-human interactions in Alaska and Canada: a review of the case history. Wildlife Society Bulletin 30(3): 831-843.

MacNulty, D.R. 2002. The predatory sequence and the influence of injury risk on hunting behavior in the wolf. Unpublished thesis. Department of Fisheries, Wildlife, and Conservation Biology. Minneapolis, MN, University of Minnesota. 71pp.

MacNulty, D.R., N. Varley, and D.W. Smith. 2001. Grizzly bear, Ursus arctos, usurps bison, Bison bison, captured by wolves, Canis lupus, in Yellowstone National Park, Wyoming. Canadian Field-Naturalist 115: 495-498.

Mao, J.S., M.S. Boyce, D.W. Smith, F.J. Singer, D.J. Vales, J.M. Vore and E.M. Merrill. 2005. Habitat selection by elk before and after wolf reintroduction in Yellowstone National Park. Journal of Wildlife Management 69(4):1691-1707.

Mech, L.D. 2004. Why I support federal wolf delisting. International Wolf 14(1):5-7.

Mech, L.D., R. T. McIntyre, D. W. Smith. 2004. Unusual behavior by bison, Bison bison, toward elk, Cervus elaphus, and wolves, Canis lupus. Canadian Field Naturalist 118: $115-118$.

Mech, L.D., D.W. Smith, K.M. Murphy, and D.R. MacNulty. 2001. Winter severity and wolf predation on a formerly wolf-free elk herd. J. of Wildlife Management 65(4): 998-1003.

Meier, T. 2001. Wolf depredation in the United States. International Wolf 11(3): 4-5.

Miller, B.,B. Dugelby, D. Foreman, C. Martinez del Rio, R. Noss, M. Phillips, R. Reading, M. Soule, J. Terborgh, and L. Wilcox. 2001. The importance of large carnivores to healthy Ecosystems. Endangered Species Update 18:202-210.

Montag, J.M., M.E. Patterson, and B. Sutton. 2003. Political and Social Viability of Predator Compensation Programs in the West. Final Project Report. Wildlife Biology Program, School of Forestry, University of Montana, Missoula, MT 59812. 136pp.

Montag, J. 2003. Compensation and predator conservation: limitations of compensation. Carnivore Damage Prevention News 6:2-6.

Montag, Jessica M. 2004. Lions, Wolves, and Bears, Oh My! Predator Compensation Programs in the West. Fair Chase, Summer: 52-54.

Montag, J.M., M.E. Patterson, and W.A. Freimund. 2005. The wolf viewing experience in the Lamar Valley of Yellowstone National Park. Human Dimensions of Wildlife 10:273-284. 
Montana Wolf Management Advisory Council, 2000. Report to the Governor. Montana Fish, Wildlife and Parks, Helena. 12 pp.

Montana Wolf Management Advisory Council, 2003. Montana gray wolf conservation and management plan. Final environmental impact statement C. Sime, ed. Montana Fish, Wildlife and Parks, Helena. 420 pp.

Musiani, M. and P. Paquet. 2004. The practices of wolf persecution, protection, and restoration in Canada and the United States. BioScience 54: 50-60.

Musiani, M., C. Mamo, L. Boitani, C. Callaghan, C. Cormack Gates, L. Mattei, E. Visalberghi, S. Breck, and G. Volpi. 2003. Wolf depredation trends and the use of fladry barriers to protect livestock in western North America. Conservation Biology 17: 1538-1547.

Musiani, M., Muhly, T., Callaghan, C., Gates, C.C., Smith, M., Stone, S. and Tosoni, E. (2004) Recovery, conservation, conflicts and legal status of wolves in western North America. Pages 51-75 in N. Fascione, A. Delach and M. Smith, (eds.). Predators and People: from conflict to conservation. Island Press, Washington, D.C., USA.

Musiani, M., T. Muhly, C. Cormack Gates, C. Callahghan, M. Smith, and E. Tosoni. 2005. Seasonality and reoccurrence of depredation and wolf control in western North America. Wildlife Society Bulletin 33:876-887.

National Research Council. 2002. Ecological dynamics on Yellowstone’s Northern Range. Committee on ungulate management in Yellowstone National Park. National Academy Press, Washington, DC. 198 pp.

Niemeyer, Carter. 2004. Crying Wolf in Central Asia. International Wolf 14:7-9.

Niemeyer, Carter. 2004. Education goes both ways with wolf depredations. International Wolf 14:14-15.

Oakleaf, J. K. 2002. Wolf-cattle interactions and habitat selection by recolonizing wolves in the northwestern United States. M.S. Thesis, University of Idaho, Moscow, Idaho.

Oakleaf, J.K., C. Mack, and D.L. Murray. 2003. Effects of wolves on livestock calf survival and movements in central Idaho. Journal of Wildlife Management 67: 299-306.

Oakleaf, J.K., D.L. Murray, E.E. Bangs, C.M. Mack, D.W. Smith, J.A. Fontaine, M.D. Jimenez, T.J. Meier, and C.C. Niemeyer. 2006. Habitat selection by recolonizing wolves in the northwestern United States. Journal of Wildlife Management 34:XXX-XXX.

Oregon Dept. of Fish and Wildlife. 2005. Oregon Wolf Conservation and Management Plan. Salem, OR. The plan is posted at www.dfw.state.or.us under wolves. 
Paquet, P.C. and L.N. Carbyn. 2003. Gray Wolf, pp. 482-510, in Wild Mammals of North America. G. Fledhamer, B.C. Thompson, and J.A. Chapman, eds. John Hopkins Press.

Patterson, M.E., J.M. Montag, and D.R. Williams. 2003. The urbanization of wildlife management: Social science, conflict, and decision making. Urban Forestry and Urban Greening 1:171-183.

Peterson, R.O., A.K. Jacobs, T.D. Drummer, L.D. Mech, and D.W. Smith. 2002. Leadership behavior in relation to dominance and reproductive status in gray wolves, Canis lupus. Canadian Journal of Zoology 80: 1405-1412.

Phillips, M., N. Fascione, P. Miller and O. Byers. 2000. Wolves in the Southern Rockies. A population and habitat viability assessment: Final Report. IUCN/SSC Conservation breeding Specialist Group, 12101 Johnny Cake Ridge Road, Apple Valley, MN 55124.

Phillips, M.K., E.E. Bangs, L.D. Mech, B.T. Kelly, and B. Fazio. 2005. Living alongside canids: lessons from the extermination and recovery of red and grey wolves in the contiguous United States. Pages 297-309 in D. MacDonald and C. Sillero, (eds.). The biology and conservation of wild canids. Oxford University Press, New York, Oxford.

Pyare, S., and J. Berger. 2003. Beyond demography and delisting: ecological recovery for Yellowstone’s grizzly bears and wolves. Biological Conservation 113:63-73

Reinhart, D. 1999. Gray wolves (Canis lupus). Pages 31-36 in Effects of winter recreation on wildlife of the Greater Yellowstone Area: a literature review and assessment, T. Olliff, K. Legg, and B. Kaeding (eds.). Report to the Greater Yellowstone Coordinating Committee. Yellowstone National Park, Wyoming. 315 pp.

Ripple, W.J., and E.J. Larsen. 2000. Historic aspen recruitment, elk, and wolves in northern Yellowstone National Park, USA. Biological Conservation 95:361-370.

Ripple, W.J., E.J. Larsen, R.A. Renkin, and D.W. Smith. 2001. Trophic cascades among wolves, elk and aspen on Yellowstone National Park’s Northern Range. Biological Conservation 102: 227-234.

Ripple, W.J., E.J. Larsen, R.A. Renkin, and D. W. Smith. 2001. Trophic cascades among wolves, elk, and aspen on Yellowstone National Park's northern range. Biological Conservation 102: 227-234.

Ripple, W.J., and R.L. Beschta. 2003. Wolf reintroduction, predation risk, and cottonwood recovery in Yellowstone National Park. Forest Ecology and Management 184: 299-313.

Ripple, W.J. and R.L. Beschta. 2004. Wolves and the ecology of fear: Can predation risk structure ecosystems? Bioscience 54(8): 755-766.

Robbins, J. 2004. Lessons from the WOLF. Scientific American. Vol. 290 (6): 76-81. 
Ruth, T.K. 2000. cougar-wolf interactions in Yellowstone National park: competition, demographics, and spatial relationships. Wildlife Conservation Society. August 2000:128.

Ruth, T. K., D. W. Smith, M. A. Haroldson, P. C. Buotte, C. Schwartz, H. Quigley, S. Cherry, K. M. Murphy, D. B. Tyers, and K. Frey. 2003. Large-carnivore response to recreational big-game hunting along the Yellowstone National Park and Absaroka-Beartooth Wilderness boundary. Wildlife Society Bulletin 31: 1150-1161.

Sands, J. 2001. Stress hormones and social behavior of wolves in Yellowstone National Park. Unpublished thesis. Biological Sciences. Bozeman, MT, Montana State University. 51pp.

Sands J. L. and S. Creel 2004. Social dominance, aggression and fecal glucocorticoid levels in a wild population of wolves, Canis lupus. Animal Behavior 67: 387-396

Schaefer, C.L. 2000. Spatial and temporal variation in wintering elk abundance and composition, and wolf response on Yellowstone's Northern Range. Unpublished thesis, Michigan Technological University. 95pp.

Shivik, J. A. In press. Tools for the Edge: What's New for Conserving Carnivores. Bioscience.

Shivik, J. A. 2004. Nonlethal alternatives for predation management. Sheep and Goat Research Journal. 19:64-71.

Shivik, J. 2001. The other tools for wolf management. WOLF! Vol 11 (2): 3-7

Shivik, J.A., A. Treves, and P. Callahan. 2003. Nonlethal techniques for managing predation: primary and secondary repellents. Conservation Biology 17: 1531-1538

Shivik, J.A., V. Asher, L. Bradley, K. Kunkel, M. Phillips, S. W. Breck, and E. Bangs. 2002. Electronic aversive conditioning for managing wolf depredation. Proceedings of the Vertebrate Pest Conference 20: 227-231.

Smith, D.W. 2000. The wolves of Yellowstone. Southeastern Wildlife Magazine.

Smith, D.W. 2001. Wildlife Art: Does it make a difference for wolves? Wildlife Art 20 (6): 102-105.

Smith, D.W. 2002. Wolf \#7: The passing of a matriarch. Yellowstone Science 10: 18-19.

Smith, D.W. 2002. Book review -- Wolves and Human Communities: Biology, Politics, and Ethics. Journal of Mammalogy 83: 915-918. 
Smith, D.W. 2002. Wolf Pack Leadership: Doug Smith explores the issue in Yellowstone and Isle Royale. Howlings: The Central Rockies Wolf Project 11(2): 10-12.

Smith, D.W. 2004. Wolf behavior: Learning to live in life or death situations. Pages 1181-1185 in Encyclopedia of Animal Behavior, Marc Bekoff (ed.), Greenwood Press, Westport, CT.

Smith, D.W. 2004. The wolf in fairy tales. Pages 39-40 in: Encyclopedia of Animal Behavior, ed., Marc Bekoff, Greenwood Press, Westport, CT.

Smith, D.W. 2005. Mixed messages about opportunistic carnivores. Conservation Biology 19:1676-1678.

Smith, D.W. 2005. Ten years of Yellowstone wolves, 1995-2005. Yellowstone Science 13(1): 733.

Smith, D.W. 2005. Ten years of Yellowstone wolves 1995-2005. Points West Magazine, Buffalo Bill Historical Center, Spring:3-6.

Smith, D.W. 2005. The predator and prey battle. Points West Magazine, Buffalo Bill Historical Center, Spring:7.

Smith, D.W. and M.K. Phillips. 2000. Northern Rocky Mountain Wolf (Canis lupus nubilus). Pages 219-223, in Endangered Animals: A Reference Guide to Conflicting issues, R.P. Reading and B. Miller, eds. Greenwood Press, Westport, CT. 383 pp.

Smith, D.W., and D.S. Guernsey. 2001. Yellowstone Wolf Project: Annual Report, 2000. National Park Service, Yellowstone Center for Resources, Yellowstone National Park, Wyoming, YCR-NR-2001-01. 14 pp.

Smith, D.W., and D.S. Guernsey. 2002. Yellowstone Wolf Project: Annual report, 2001. National Park Service, Yellowstone Center for Resources, Yellowstone National Park, Wyoming, YCR-NR-2002-04.

Smith, D.W. and R. McIntyre. 2002. Wolf pack size: How did the Druid Peak Pack get to be so big? International Wolf 12(1): 4-7.

Smith, D.W. and D.R. Stahler. 2003. Management of habituated wolves in Yellowstone National Park. Yellowstone National Park: Yellowstone Center for Resources, National Park Service.

Smith, D.W. and G. Ferguson. 2005. Decade of the wolf: Returning the wild to Yellowstone. Lyons Press, Guilford, CT, 212 pp. 
Smith, D.W., W.G. Brewster, and E.E. Bangs. 1999. Wolves in the Greater Yellowstone Ecosystem: restoration of a top carnivore in a complex management environment. Pages 103-125 in Carnivores in Ecosystems, T.W. Clark, A.P. Curlee, S.C. Minta, and P.M. Kareiva. (eds.). Yale University Press.

Smith, D.W., K.M. Murphy, and D.S. Guernsey. 1999. Yellowstone Wolf Project: Annual Report, 1998. National Park Service, Yellowstone Center for Resources, Yellowstone National Park, Wyoming, YCR-NR-99-1. 14 pp.

Smith, D.W., K.M. Murphy, and D.S. Guernsey. 2000. Yellowstone Wolf Project: Annual Report, 1999. National Park Service, Yellowstone Center for Resources, Yellowstone National Park, Wyoming, YCR-NR-2000-01.

Smith, D.W., K.M. Murphy, and S. Monger. 2001. Killing of Bison (Bison bison) calf, by a wolf (Canis lupus), and four coyotes (Canis latrans), in Yellowstone National Park. Canadian Field-Naturalist 115 (2): 343-345.

Smith, D.W., R.O. Peterson, and D. Houston. 2003. Yellowstone after wolves. BioScience 53(4): 330-340.

Smith, D.W., D.R. Stahler, and D.S. Guernsey. 2003. Yellowstone Wolf Project: Annual Report 2002. National Park Service, Yellowstone Center for Resources, Yellowstone National Park, Wyoming, YCR-NR-2003, 1-14.

Smith, D. W., D. R. Stahler, and D. S. Guernsey. 2003. Yellowstone Wolf Project Winter Study Handbook. Yellowstone Center for Resources.

Smith, D. W., D. R. Stahler and D. S. Guernsey. 2004. Yellowstone Wolf Project: Annual Report 2003. National Park Service, Yellowstone Center for Resources, Yellowstone National Park, Wyoming. YCR-NR-2004-04. pp. 1-18.

Smith, D.W., L.D. Mech, M. Meagher, W.E. Clark, R. Jaffe, M.K. Phillips, and J.A. Mack. 2000. Wolf-bison interactions in Yellowstone National Park. Journal of Mammalogy 81(4): 1128-1135.

Smith, D.W., K.M. Murphy, R. McIntyre, T. Zieber, G. Plumb, B. Phillips, B. Chan, J. Knuth Folts, D. Chalfant, and B. Suderman. 2000. Managing wolves and humans in Lamar Valley: A final report on the Druid road project 2000. YNP report, 5pp.

Smith, D.W., R. McIntyre, E. Cleere, G. Plumb, B. Phillips, B. Chan, M. Ross, J. Knuth Folts, D. Chalfant, and B. Suderman. 2001. Managing wolves and humans in Lamar Valley: A final report on the Druid road project 2001. YNP report. 7pp. 
Smith, D.W., D. R. Stahler, R. McIntyre, D. Graf, E. West, G. Plumb, B. Phillips, B. Chan, M. Ross, J. Knuth Folts, D. Chalfant, and B. Suderman. 2002. Managing wolves and humans in Lamar Valley: A final report on the Druid road project 2002. YNP report. 9pp.

Smith, D.W., D.R. Stahler, K.M. Murphy, D.S. Guernsey, R.T. McIntyre, E.E. Bangs, and M.K. Phillips. In preparation. Colonization and population expansion of reintroduced wolves in Yellowstone National park. Journal of Mammalogy.

Smith, D. W. 2005, Ten Years of Yellowstone Wolves, 1995-2005. Yellowstone Science 13 (1): 7-33.

Smith, D.W., T.D. Drummer, K.M. Murphy, D.S. Guernsey, and S.B. Evans. 2004. Winter prey selection and estimation of wolf kill rates in Yellowstone National Park. Journal of Wildlife Management 68: 153-166.

Smith, D.W., D. Murray, E. Bangs, J. Oakleaf, C. Mack, J. Fontaine, D. Boyd, M. Jimenez, D. Pletscher, C. Niemeyer, T. Meier, D. Stahler, D. Guernsey, J. Holyan. In preparation. Survival of colonizing wolves in the northern Rocky Mountains of the United States, 1982-2004. Wildlife Monographs.

Smith, D. W., D. Stahler, D. Guernsey, and E. Bangs. 2006. Wolf Restoration in Yellowstone National Park, in D. R. McCullough, K. Kaji and M.Yamanaka (eds.), "Wildlife in Shiretoko and Yellowstone National Parks: Lessons in Wildlife Conservation from Two World Heritage Sites". Shiretoko Nature Foundation, Hokkaido, Japan.

Stahler, D.R. 2000. Interspecific interactions between the common raven (Corvus corax) and the gray wolf (Canis lupus) in Yellowstone National Park, Wyoming: Investigations of a predator and scavenger relationship. Unpublished thesis, University of Vermont. 105pp.

Stahler, D.R., B. Heinrich, and D.W. Smith. 2002. Common ravens, Corvus corax, preferentially associate with gray wolves, Canis lupus, as a foraging strategy in winter. Animal Behavior 64: 283-290.

Stahler, D.R., D.W. Smith, and R. Landis. 2002. The acceptance of a new breeding male into a wild wolf pack. Canadian Journal of Zoology 80: 360-365.

Stahler, D.R., D.W. Smith, R. McIntyre, E. West, B. Phillips, B. Chan, M. Ross, J. Knuth Folts, D. Chalfant, and B. Suderman. 2003. Managing wolves and humans in Lamar Valley: A final report on the Druid road project 2003. YNP Report. 9 pp.

Stone, S.A., N. Fascione, C. Haney, and G. Schrader, A. Weiss, and M. Musiani. 2005. Compensation: a method for promoting wolf conservation. Abstract for First Diversitas Conference on International Biodiversity. Oaxaca, Mexico. November 9-12, 2005. (Publication pending). 
Switalski, T.A., T. Simmons, S.L. Duncan, A.S. Chavez, and R.H. Schmidt. 2002. Wolves in Utah. An analysis of potential impact and recommendations for management. Utah Cooperative Fish and Wildlife Research Unit, Utah State University. Natural Resource and Environmental Issues, Vol. X.

Taper, M.L., and P.J.P. Gogan. 2002. The northern Yellowstone elk: Density dependence and climatic conditions. Journal of Wildlife Management 66(1): 106-122

Thurston, L.M. 2002. Homesite attendance as a measure of alloparental and parental care by gray wolves (Canis lupus) in northern Yellowstone National Park. Unpublished thesis, Texas A and M University. 175pp.

Trapp, J. R. 2004. Wolf den site selection in the Northern Rocky Mountains. Thesis, Prescott College, Prescott, Arizona, USA.

Trapp, J.R. P. Beier, C. Mack, D.R. Parsons, P.C. Paquet. In prep. Wolf den site selection in the northern Rocky Mountains.

USDA./APHIS/Idaho Wildlife Services. 1999. Wolf Activity Report, Fiscal Year 1999. USDA/APHIS/Wildlife Services, 9134 West Black Eagle Drive, Boise ID 83709. 11pp.

USDA./APHIS/Idaho Wildlife Services. 2001. Wolf Activity Report, Fiscal Year 2000. USDA/APHIS/Wildlife Services, 9134 West Black Eagle Drive, Boise ID 83709. 14pp.

USDA./APHIS/Idaho Wildlife Services. 2002. Wolf Activity Report, Fiscal Year 2001. USDA/APHIS/Wildlife Services, 9134 West Black Eagle Drive, Boise ID 83709. 13pp.

USDA/APHIS/Idaho Wildlife Services. 2003. Wolf Activity Report, Fiscal Year 2002. USDA/APHIS/Wildlife Services, 9134 West Black Eagle Drive, Boise ID 83709. 13pp.

USDA./APHIS/Idaho Wildlife Services. 2004. Wolf Activity Report, Fiscal Year 2003. USDA/APHIS/Wildlife Services, 9134 West Black Eagle Drive, Boise ID 83709. 15pp.

USDA./APHIS/Idaho Wildlife Services. 2005. Wolf Activity Report, Fiscal Year 2004. USDA/APHIS/Wildlife Services, 9134 West Black Eagle Drive, Boise ID 83709. 14pp.

USDA./APHIS/Idaho Wildlife Services. 2006. Wolf Activity Report, Fiscal Year 2005. USDA/APHIS/Wildlife Services, 9134 West Black Eagle Drive, Boise ID 83709. 14pp.

U.S. Fish and Wildlife Service. 1987. Northern Rocky Mountain Wolf Recovery Plan. U.S. Fish and Wildlife Service, Denver, Colorado. 119pp.

U.S. Fish and Wildlife Service. 1994. Final Environmental Impact Statement, The reintroduction of gray wolves to Yellowstone National Park and Central Idaho. U.S. Fish and Wildlife Service, Helena, Montana. 
U.S. Fish and Wildlife Service. 2000. Proposal to reclassify and remove the gray wolf from the list of endangered and threatened wildlife in portions of the conterminous United States. Federal Register 65(135): 43449-43496.

U.S. Fish and Wildlife Service. 2003. Endangered and threatened wildlife and plants; final rule to reclassify and remove the gray wolf from the list of endangered and threatened wildlife in portions of the conterminous United States; establishment of two special regulations for threatened gray wolves; final and proposed rules. Federal Register 68: 15803-15875.

U.S. Fish and Wildlife Service. 2005. Endangered and threatened wildlife and plants;

Regulation for nonessential experimental populations of the western distinct population segment of the gray wolf; final rule. Federal Register 70(4): 1286-1311.

U.S. Fish and Wildlife Service. 2006. Endangered and threatened wildlife and plants; Advanced Notice of Proposed Rulemaking- Establishment of a Rocky Mountain Distinct Population Segment and delisting. Federal Register 71(26):6634-6660.

U.S. Fish and Wildlife Service, Nez Perce Tribe, National Park Service, and USDA Wildlife Services. 2000. Rocky Mountain Wolf Recovery 1999 Annual Report. USFWS, Ecological Services, 100 N Park, Suite 320, Helena MT. 23pp. http://westerngraywolf.fws.gov/annualreports.htm

U.S. Fish and Wildlife Service, Nez Perce Tribe, National Park Service, and USDA Wildlife Services. 2001. Rocky Mountain Wolf Recovery 2000 Annual Report. USFWS, Ecological Services, 100 N Park, Suite 320, Helena MT. 35pp. http://westerngraywolf.fws.gov/annualreports.htm

U.S. Fish and Wildlife Service, Nez Perce Tribe, National Park Service, and USDA Wildlife Services. 2002. Rocky Mountain Wolf Recovery 2001 Annual Report. T. Meier, ed. USFWS, Ecological Services, 100 N Park, Suite 320, Helena MT. 41pp. http://westerngraywolf.fws.gov/annualreports.htm

U.S. Fish and Wildlife Service, Nez Perce Tribe, National Park Service, and USDA Wildlife Services. 2003. Rocky Mountain Wolf Recovery 2002 Annual Report. T. Meier, ed. USFWS, Ecological Services, 100 N Park, Suite 320, Helena MT. 64pp. http://westerngraywolf.fws.gov/annualreports.htm

U.S. Fish and Wildlife Service, Nez Perce Tribe, National Park Service, and USDA Wildlife Services. 2004. Rocky Mountain Wolf Recovery 2003 Annual Report. T. Meier, ed. USFWS, Ecological Services, 100 N Park, Suite 320, Helena MT. 65pp. http://westerngraywolf.fws.gov/annualreports.htm 
U.S. Fish and Wildlife Service, Nez Perce Tribe, National Park Service, and USDA Wildlife Services. 2005. Rocky Mountain Wolf Recovery 2004 Annual Report. D. Boyd, editor. USFWS, Ecological Services, 100 N. Park, Suite 320, Helena, MT. http://westerngraywolf.fws.gov

Vucetich, J.A., D.W. Smith, and D.R. Stahler. 2005. Influence of Harvest, climate, and wolf predation of Yellowstone elk, 1961-2004. Oikos 111:259-270

White, P.J. and R.A. Garrott. 2006. Northern Yellowstone elk after wolf restoration. Wildlife Society Bulletin 33:942-955.

White, P.J., D.W. Smith, J.W. Duffield, M.D. Jimenez, T. McEneaney, and G. Plumb. 2005. Wolf EIS Predictions and Ten-Year Appraisals. Yellowstone Science 13:34-41.

Whittington, J., C.C. St. Clair, and G. Mercer. 2004. Path tortuosity and the permeability of roads and trails to wolf movement. Ecology and Society 9(1): 4.

Wilmers, C. C. and W. M. Getz. 2004. Simulating the effects of wolf-elk population dynamics on resource flow to scavengers. Elsevier 177: 193-208.

Wilmers, C.C., and D.R. Stahler. 2002. Constraints on active-consumption rates in gray wolves, coyotes, and grizzly bears. Canadian Journal of Zoology. 80: 1256-1261.

Wilmers, C.C., D.R. Stahler, R.L. Crabtree, D.W. Smith, and W.M. Getz. 2003. Resource dispersion and consumer dominance: scavenging at wolf- and hunter-killed carcasses in Greater Yellowstone, USA. Ecology Letters 6: 996-1003.

Wilmers, C.C., R.L. Crabtree, D.W. Smith, K.M. Murphy, and W.M. Getz. 2003. Trophic facilitation by introduced top predators: gray wolf subsidies to scavengers in Yellowstone National Park. Journal of Animal Ecology 72: 909-916.

Wondrak Biel, A. and D.W. Smith. 2005. Yellowstone wolf found near Denver. NPS Natural Resource Year in Review - 2004. National Park Service, U.S Department of the Interior, Washington D.C., ISSN 1544-5429.

Woodroffe, R., S. Thirgood, and A. Rabinowitz, eds. People and wildlife: coexistence or conflict? Cambridge University Press, Cambridge, United Kingdom. 497 pp.

Wright, G.J. 2003. An analysis of the northern Yellowstone elk herd: population reconstruction and selection of elk by wolves and hunters. Unpublished thesis, Michigan Technological University. 124pp. 


\section{APPENDIX 1}

\section{MONTANA CONTACT INFORMATION}

\section{Montana Fish, Wildlife \& Parks}

Carolyn Sime

Montana Fish, Wildlife \& Parks

Gray Wolf Program Coordinator, Helena

406-461-0587

casime@mt.gov

Kent Laudon

Montana Fish Wildlife \& Park

Wolf Management Specialist, Kalispell

406-751-4586

laudon@mt.gov

Jon Trapp

Montana Fish, Wildlife \& Parks

Wolf Management Specialist, Red Lodge

406-425-1132

jtrapp@cablemt.net

Liz Bradley

Montana Fish, Wildlife \& Parks

Wolf Management Specialist, Dillon

406-865-0017

liz_bradley@7pks.com\
Mike Ross

Montana Fish, Wildlife \& Parks

Wolf Management Specialist, Bozeman

406-581-3664

mross@mt.gov

Val Asher

Montana Fish, Wildlife \& Parks Volunteer

Wolf Management Specialist, Bozeman

406-581-3281

valasher@montana.net

\section{USDA Wildlife Services}

(to request investigations of injured or dead livestock):

Larry Handegard

USDA WS State Director, Billings

(406) 657-6464 (w)

Kraig Glazier

USDA WS West District Supervisor, Helena (406) 458-0106 (w)

Jim Hoover

USDA WS East District Supervisor, Columbus

(406) 322-4303 (w)

\section{Montana Fish, Wildlife \& Parks Wolf Specialist Areas of Responsibilities}

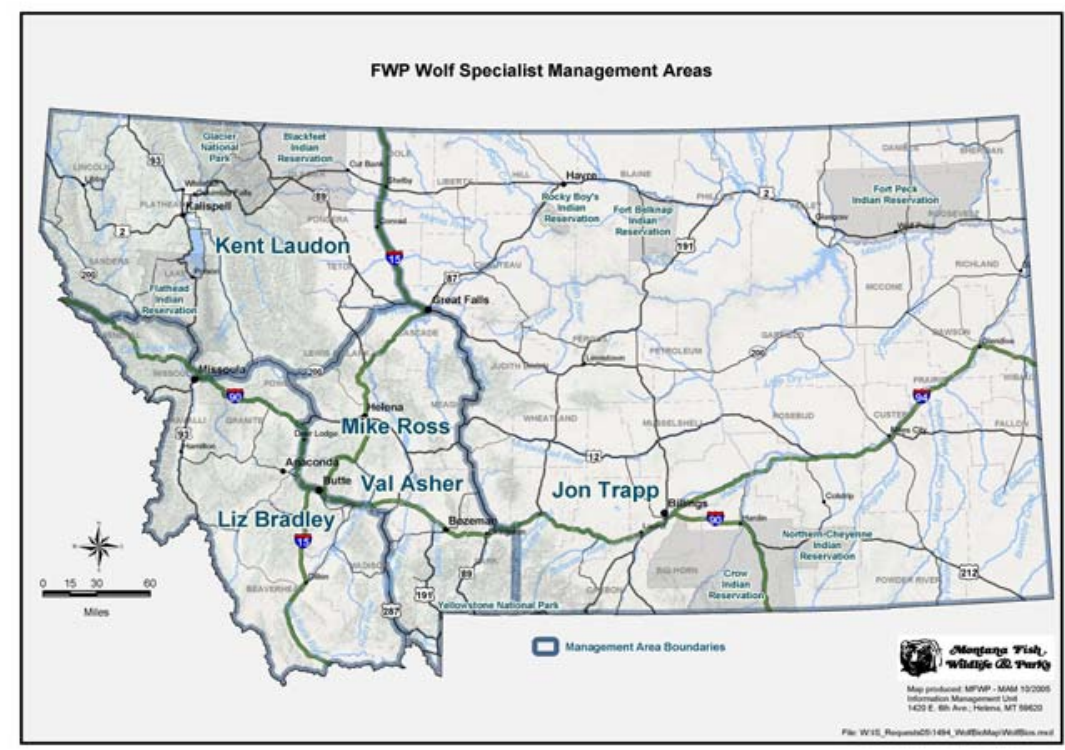




\section{MONTANA FISH WILDLIFE \& PARKS ADMINISTRATIVE REGIONS}

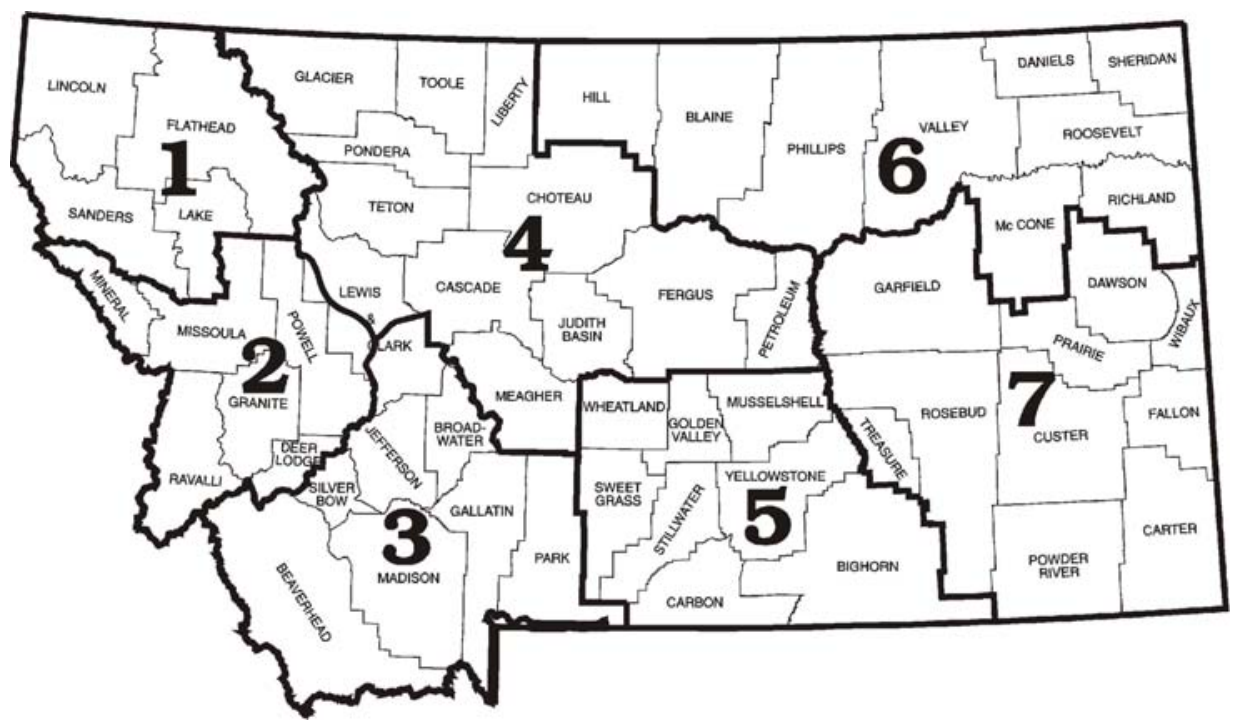

STATE

HEADQUARTERS

MT Fish, Wildlife \& Parks

$1420 \mathrm{E}^{\text {th }}$ Avenue

PO Box 200701

Helena, MT 59620-0701

(406) 444-2535

\section{REGION 1}

490 N Meridian Rd

Kalispell, MT 59901

(406) 752-5501

REGION 2

3201 Spurgin Rd

Missoula, MT 59804

(406) 542-5500
REGION 3

1400 South $19^{\text {th }}$

Bozeman, MT 59718

(406) 994-4042

HELENA Area Res Office

(HARO)

930 Custer Ave W

Helena, MT 59620

(406) 495-3260

BUTTE Area Res Office

(BARO)

1820 Meadowlark Ln

Butte, MT 59701

(406) 494-1953
REGION 4

4600 Giant Springs Rd

Great Falls, MT 59405

(406) 454-5840

LEWISTOWN Area Res

Office (LARO)

215 W Aztec Dr

PO Box 938

Lewistown, MT 59457

(406) 538-4658

\section{REGION 5}

2300 Lake Elmo Dr

Billings, MT 59105

(406) 247-2940

\section{TO REPORT A DEAD WOLF OR POSSIBLE ILLEGAL ACTIVITY:}

U.S.Fish and Wildlife Service

- Special Agent, Missoula MT: (406) 329-3000

- Special Agent, Bozeman, MT: (406) 582-0336

- Special Agent, Casper, WY: (307) 261-6365

Montana Fish, Wildlife \& Parks

- Dial 1-800-TIP-MONT

TO SUBMIT WOLF REPORTS ELECTRONICALLY AND TO LEARN MORE ABOUT THE MONTANA WOLF PROGRAM, SEE:

- www.fwp.mt.gov/wildthings/wolf 


\section{APPENDIX 2 \\ Gray Wolf Chronology in Montana}

1800

- Wolves are common throughout Montana.

1884

- Wolf-bounty law initiates Montanas official eradication effort.

1915

- Federal authorities begin wolf control in the West.

1925

- Wolf populations eliminated from most of the West.

1936

- Gray wolf believed extinct in Montana although wolves and wolf sign still occasionally observed.

1950

- Wolves still seen in Wyoming, Montana, and Idaho occasionally but no self-sustaining breeding documented; wolves, likely dispersing from Canada, are killed in Montana and Idaho in every decade through 2000.

1973

- Montana protects wolves as state endangered species.

1974

- Wolves protected under federal Endangered Species Act of 1973.

1979

- A wolf is monitored in British Columbia, just north of Glacier National Park.

1980

- A lone wolf kills livestock near Big Sandy, Montana and is killed by the U.S. Fish and Wildlife Service. This is Montana's first documented wolf depredation in more than 50 years.

1986

- A wolf den is confirmed in Glacier National Park. The Magic Pack establishes a territory in the North Fork Flathead River valley, in the western portion of Glacier National Park.

- A pack denned on the Blackfeet Reservation, but was not discovered until 1987 when they began to depredate on livestock. 
- Camas Pack established in the North Fork of the Flathead River valley in Glacier National Park.

- First livestock depredation occurs on the Blackfeet Reservation.

1990

- The U.S. Congress establishes a Wolf Management Committee to recommend wolf recovery strategies for Yellowstone National Park and central Idaho.

1991

- Congress directs the US Fish and Wildlife Service to prepare a Draft Environmental Impact Statement on wolf recovery in Yellowstone National Park and central Idaho.

1993

- An estimated 45 wolves in five packs occupy the federal Northwestern Montana Recovery Area. One pack establishes west of Helena, founded by a female wolf which disperesed from Canada.

1994

- Federal EIS on the reintroduction of wolves into Yellowstone National Park and central Idaho completed. Wolves to be reintroduced into Yellowstone National Park and central Idaho for three to five years under the Endangered Species Acts experimental, nonessential rules that grant additional management flexibility. Wolf recovery is defined as 30 breeding pairs--an adult male and an adult female raising two or more pups to Dec. 31--in Montana, Idaho, and Wyoming for three successive years.

1995

- Fifteen wolves from four packs captured in Canada are relocated to Yellowstone National Park and 17 individual wolves are released in central Idaho.

1996

- Yellowstone National Park receives 17 more wolves from Canada and 10 wolf pups from a depredating pack in northwestern Montana. Twenty wolves are released in central Idaho and first pups are produced in the wild.

1999

- Governors of Montana, Idaho, and Wyoming renew a 1997 Memorandum of Understanding to coordinate public involvement to pursue plans to manage a recovered wolf population in the northern Rockies and to assure a timely delisting.

- Montana Governor Marc Racicot appoints 12 Montana citizens to the Montana Wolf Management Advisory Council. The council, chaired by rancher Chase Hibbard of Helena, is charged to advise Montana Fish, Wildlife \& Parks on wolf management in anticipation of the wolf's delisting. 
- US Fish and Wildlife Service determines there are 30 breeding pair in the tri-state Rocky Mountain Recovery Area, marking 2000 as the first year of the three-year countdown to meet wolf population recovery goals.

- An estimated 97 wolves in 8 breeding pairs are counted in Montana.

2001

- Montana Wolf Management Advisory Council presents its Report to the Governor to Governor Judy Martz, who directs MFWP to draft wolf conservation and management planning document.

- Montana Legislature removes the gray wolf from Montana's list of predatory species once the wolf is delisted. Upon delisting, wolves will be legally reclassified in Montana as species in need of management. New law includes provisions for the defense of life and private property when a wolf is attacking, killing, or threatening to kill a person, or livestock.

- Montana Fish, Wildlife \& Park's draft of the Montana Wolf Conservation and Management Planning Document is reviewed, amended and approved by the Montana Wolf Management Advisory Council.

- An estimated 35 breeding pair, in 51 packs, are counted in the tri-state Rocky Mountain Recovery Area, totaling about 550 wolves. The US Fish and Wildlife Service determines 2001 is second year of the three-year countdown to trigger an official proposal to delist the wolf.

- An estimated 123 wolves in 7 breeding pairs are counted in Montana.

2002

- Montana Wolf Conservation and Management Planning Document is released in January. Montana Fish, Wildlife \& Parks begins to develop an environemntal impact statement (EIS) on the state management of wolves. The public is invited to participate at community work sessions around the state and asked to identify issues and help develop management alternatives.

- Montana Fish, Wildlife \& Parks develops draft EIS with five alternatives.

- An estimated 43 breeding pairs are counted in the tri-state Rocky Mountain Wolf Recovery Area, totaling about 663 wolves. The US Fish and Wildlife Service determines 2002 is the third year of the three-year countdown to trigger official proposal to delist the wolves.

- U.S. Fish and Wildlife Service announces that the northern Rockies gray wolf population has achieved biological recovery under the federal Endangered Species Act.

- An estimated 183 wolves in 17 breeding pairs are counted in Montana.

2003

- Montana's EIS process includes a 60-day public comment period and statewide community work sessions. The final EIS recommends the adoption of the "updated council" alternative. The Montana Fish, Wildlife \& Parks Commission approves the adoption of the preferred alternative - the Council's Update.

- State conservation and management plans completed by Montana, Idaho, and Wyoming and submitted to USFWS.

- States of Montana, Idaho, and Wyoming request funding from Congress. 
- U.S. Fish and Wildlife Service expected to begin the official administrative process of delisting gray wolves in the northern Rockies.

- An estimated 761 wolves in 51 breeding pairs are counted in the tri-state Rocky Mountain Wolf Recovery Area at the end of the year.

- An estimated 182 wolves in 10 breeding pairs are counted in Montana.

2004

- U.S. Fish and Wildlife Service approves state management plans from Montana and Idaho and rejects Wyoming's plan. Delisting is officially delayed until the impasse is resolved.

- Montana Fish, Wildlife \& Parks and the Montana Fish, Wildlife \& Parks Commission approve amending the Record of Decision to pave the way for interim state participation in northwest Montana through a limited cooperative agreement.

- In February, Montana Fish, Wildlife \& Parks and U.S. Fish and Wildlife Service complete a cooperative agreement covering northwest Montana.

- Montana Fish, Wildlife \& Parks receives federal funding and hires staff who begin implementing the state plan prior to delisting and in consultation with U.S. Fish and Wildlife Service.

- Montana Fish, Wildlife \& Parks begins close coordination with USDA Wildlife Services to investigate and resolve wolf-livestock conflicts.

- An estimated 835 wolves in 66 breeding pairs are counted in the tri-state Rocky Mountain Wolf Recovery Area at the end of the year.

- An estimated 153 wolves in 15 breeding pairs are counted in Montana.

2005

- Wolves in northwest Montana recoveyr area reclassified as "endangered" by court order.

- U.S. Fish and Wildlife Service adopts more flexibile regulations [known as 10(j) regulations] for the experimental population areas of Montana and Idaho.

- Montana Fish, Wildlife \& Parks and U.S. Fish and Wildlife Service complete a cooperative agreement paving the way for Montana to assume independent and full reponsibility for wolf management and conservation statewide. Montana begins implementing the state plan to the extent allowed by federal regulations throughout the state. Funding from U.S. Fish and Wildlife Service and through special Congressional appropriations fund Montana Fish, Wildlife \& Park's wolf team.

- Montanans form a diverse working group of private citizens, non-governmental organizations, and state and federal agencies to begin developing the Montana Livestock Loss Reduction and Mitigation Program. Work is ongoing.

- An estimated 256 wolves in 19 breeding pairs are counted in Montana. 


\section{APPENDIX 3}

\section{NORTHERN ROCKIES WOLF PACK TABLES}

Table 1a. Northwest Montana wolf recovery area: wolf packs and population data 2005.

Table 1b. Montana outside of NWMT recovery area (and statewide totals): wolf packs and population data 2005. .76

Table 2. Wyoming wolf packs and population data 2005, and totals for Greater Yellowstone recovery area. 78

Table 3. Idaho wolf packs and population data 2005, and totals for Central Idaho recovery area.

Table 4a. Northern Rocky Mountains minimum fall wolf population and breeding pairs 1979-2005, by recovery area.

Table 4b. Northern Rocky Mountains minimum fall wolf population and breeding pairs 1979-2005, by state.

Table 5a. Northern Rocky Mountain states: confirmed wolf depredation and wolf management (by recovery area), 1987-2005.

Table 5b. Northern Rocky Mountain states: confirmed wolf depredation and wolf management (by state), 19872005. 


\begin{tabular}{|c|c|c|c|c|c|c|c|c|c|c|c|c|c|c|c|}
\hline \multirow{2}{*}{$\begin{array}{c}\text { REF. } \\
\# \\
\end{array}$} & \multirow[b]{2}{*}{ WOLF PACK 1} & \multirow{2}{*}{$\begin{array}{c}\text { RECOV } \\
\text { AREA } \\
\end{array}$} & \multirow[b]{2}{*}{ STATE } & \multicolumn{3}{|c|}{ PACK SIZE DEC 2005} & \multicolumn{3}{|c|}{ MORTALITIES } & \multirow{2}{*}{$\begin{array}{c}\text { KNOWN } \\
\text { DISPERSED }\end{array}$} & \multirow[b]{2}{*}{ MISSING 4} & \multicolumn{2}{|c|}{ CONTROL } & \multicolumn{2}{|c|}{ CONFIRMED LOSSES 6} \\
\hline & & & & ADULT & PUP & TOT & NAT & HUMAN 2 & UNKN 3 & & & KILLED 5 & MOVED & CATTLE SHEEP & DOGS OTHER \\
\hline 1 & Candy Mtn & NWMT & MT & 5 & 4 & 9 & & & & & & & & & \\
\hline 2 & Fish Creek \# & NWMT & MT & 3 & 9 & 12 & & & & & & & & & \\
\hline 3 & Fishtrap & NWMT & MT & $?$ & 1 & 7 & & & & & 1 & & & 1 & \\
\hline 4 & Great Bear & NWMT & MT & 2 & $?$ & 2 & & & & & & & & & \\
\hline 5 & Halfway & NWMT & MT & 3 & 4 & 7 & & & & & & 1 & & 3 & \\
\hline 6 & Hog Heaven & NWMT & MT & $?$ & $?$ & 3 & & 1 & & & & & & & \\
\hline 7 & Kintla & NWMT & MT & 6 & 3 & 9 & & & 1 & & 1 & & & & \\
\hline 8 & Kootenai South & NWMT & MT & 5 & 2 & 7 & & & & & & & & & \\
\hline 9 & Lazy Creek & NWMT & MT & 4 & 5 & 9 & & & & & & & & & \\
\hline 10 & Livermore & NWMT & MT & $?$ & $?$ & 4 & & & & & & & & & \\
\hline 11 & Marias & NWMT & MT & $?$ & $?$ & 6 & & 1 & & & & & & & \\
\hline 12 & Murphy Lake & NWMT & MT & 1 & $?$ & 3 & & 1 & & & & & & & \\
\hline 13 & $\underline{\text { Ninemile }}$ & NWMT & MT & 2 & 5 & 7 & & & 1 & & & & & & \\
\hline 14 & Red Shale & NWMT & MT & 4 & 3 & 7 & & & & & & & & & \\
\hline 15 & Spotted Bear & NWMT & MT & 4 & 2 & 6 & & & & & & & & & \\
\hline 16 & Spotted Dog & NWMT & MT & $?$ & $?$ & 11 & & & & & & & & 1 & \\
\hline 17 & Superior \# & NWMT & MT & 2 & 0 & 2 & & & & & & & & & \\
\hline 18 & Whitefish & NWMT & MT & $?$ & $?$ & 7 & & & & & 1 & & & & \\
\hline \multirow[t]{3}{*}{19} & $\underline{\text { Wolf Prairie }}$ & NWMT & MT & 3 & 5 & 8 & & 1 & & & & & & & \\
\hline & Misc/Lone & NWMT & MT & & & & & 2 & 1 & & & 1 & & 4 & \\
\hline & MT Total in NWMT & NWMT & MT & $44+$ & $43+$ & 126 & 0 & 6 & 3 & 0 & 3 & 2 & 0 & 1 & 0 \\
\hline
\end{tabular}

1 Underlined packs are counted as breeding pairs toward recovery goals.

2 Excludes wolves killed in control actions.

3 Does not include pups that disappeared before winter.

4 Collared wolves that ceased transmitting in 2005.

5 Includes agency lethal control.

6 Includes only domestic animals confirmed killed by wolves.

\# Border pack shared with State of Idaho; dens in Montana and majority of time in Montana. 


\begin{tabular}{|c|c|c|c|c|c|c|c|c|c|c|c|c|c|c|c|c|c|}
\hline \multirow{3}{*}{$\begin{array}{c}\text { REF. } \\
\#\end{array}$} & \multicolumn{17}{|c|}{ Montana portion of Greater Yellowstone Experimental Area } \\
\hline & \multirow[b]{2}{*}{ WOLF PACK 1} & \multirow{2}{*}{$\begin{array}{c}\text { RECOV } \\
\text { AREA }\end{array}$} & \multirow[b]{2}{*}{ STATE } & \multicolumn{3}{|c|}{ PACK SIZE DEC 2005} & \multicolumn{3}{|c|}{ MORTALITIES } & \multirow{2}{*}{$\begin{array}{c}\text { KNOWN } \\
\text { DISPERSED } \\
\end{array}$} & \multirow[b]{2}{*}{ MISSING 4} & \multicolumn{2}{|c|}{ CONTROL } & \multicolumn{4}{|c|}{ CONFIRMED LOSSES 6} \\
\hline & & & & ADULT & PUP & TOT & NAT & HUMAN 2 & UNKN 3 & & & KILLED 5 & MOVED & CATTLE & SHEEP & DOGS & OTHER \\
\hline & Phantom ${ }^{7}$ & GYA & MT & 0 & 0 & 0 & & & & & & 4 & & 2 & 1 & & \\
\hline 20 & Rosebud & GYA & MT & 3 & 0 & 3 & & & & & & & & & & & \\
\hline 21 & Moccasin Lake & GYA & MT & 2 & 0 & 2 & & & & & & & & & & & \\
\hline 22 & Mission Creek & GYA & MT & 3 & 0 & 3 & 1 & & & & & & & & & & \\
\hline 23 & SW 28 & GYA & MT & 2 & 0 & 2 & & & & & & & & & & & \\
\hline 24 & SW 57 & GYA & MT & 2 & 0 & 2 & & & & & & 1 & & 1 & & & \\
\hline 25 & Carbonate Mountain & GYA & MT & 5 & 0 & 5 & & & & & & & & & & & \\
\hline 26 & Buffalo Fork & GYA & MT & 2 & 1 & 3 & & & & & & & & & & & \\
\hline \multirow[t]{2}{*}{27} & Mill Creek & GYA & MT & 2 & 0 & 2 & & & & & & 2 & & & & & \\
\hline & Lone Bear $^{7}$ & GYA & MT & 0 & 0 & 0 & & & & 1 & & 3 & & & & & \\
\hline 28 & Donohue & GYA & MT & 2 & $?$ & 2 & & & & & 1 & & & & & & \\
\hline 29 & Chief Joe $\%$ & GYA & MT & 5 & 0 & 5 & 1 & 1 & & & & & & & & & \\
\hline 30 & Casey Lake & GYA & MT & 3 & 0 & 3 & 1 & & & & & & & & & & \\
\hline \multirow[t]{3}{*}{31} & Deadhorse & GYA & MT & 2 & 4 & 6 & & & & & & & & & & & \\
\hline & Bear Creek $^{7}$ & GYA & MT & 0 & 0 & 0 & & & & & 1 & & & & & & \\
\hline & Homestead $^{7}$ & GYA & MT & 0 & 0 & 0 & 2 & 2 & & & 1 & & & & & & \\
\hline 32 & Freezeout & GYA & MT & $?$ & $?$ & 5 & & & & 1 & & 6 & & 2 & & & \\
\hline 33 & Beartrap & GYA & MT & 3 & 5 & 8 & & & & & & & & & & & \\
\hline \multirow[t]{2}{*}{34} & Wedge & GYA & MT & 2 & 5 & 7 & & & 1 & & & & & 1 & & & \\
\hline & Dillon Pair $^{7}$ & GYA & MT & 0 & 0 & 0 & & & & & & 2 & & & & & \\
\hline \multirow[t]{3}{*}{35} & Sage Creek & GYA & MT & 2 & $?$ & 6 & & & & & & & & & & & \\
\hline & Misc/Lone & GYA & MT & 2 & 0 & 2 & & 2 & & & & 1 & & 1 & 25 & 1 & \\
\hline & MT Total in GYA & GYA & MT & $42+$ & $15+$ & 66 & 5 & 5 & 1 & 2 & 3 & 19 & 0 & 7 & 26 & 1 & 0 \\
\hline
\end{tabular}

1 Underlined packs are counted as breeding pairs toward recovery goals.

2 Excludes wolves killed in control actions.

3 Does not include pups that disappeared before winter.

4 Collared wolves that ceased transmitting in 2005

5 Includes agency lethal control and take by private citizens under 10j regulation.

6 Includes only domestic animals confirmed killed by wolves.

7 Pack did not exist on December 31, 2005 and is not displayed on the map; see pack narrative.

$\%$ Dens just inside the Yellowstone National Park boundary but nearly $100 \%$ of the territory is within the State of Montana. 


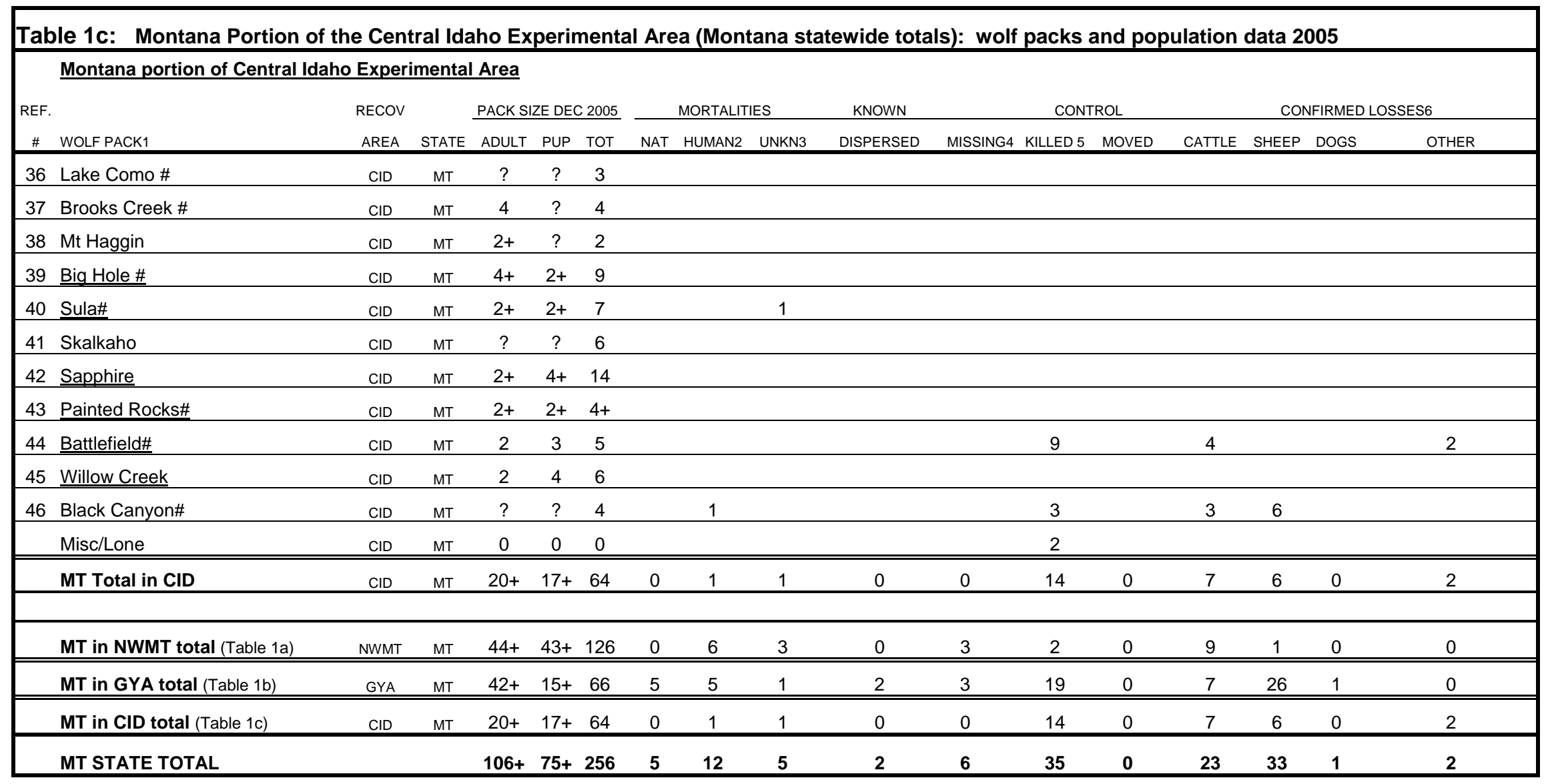

1 Underlined packs are counted as breeding pairs toward recovery goals.

2 Excludes wolves killed in control actions.

3 Does not include pups that disappeared before winter.

4 Collared wolves that ceased transmitting in 2005.

5 Includes agency lethal control and take by private citizens under 10j regulation.

6 Includes only domestic animals confirmed killed by wolves.

\# Border pack shared with State of Idaho; dens in Montana and majority of time in Montana. 


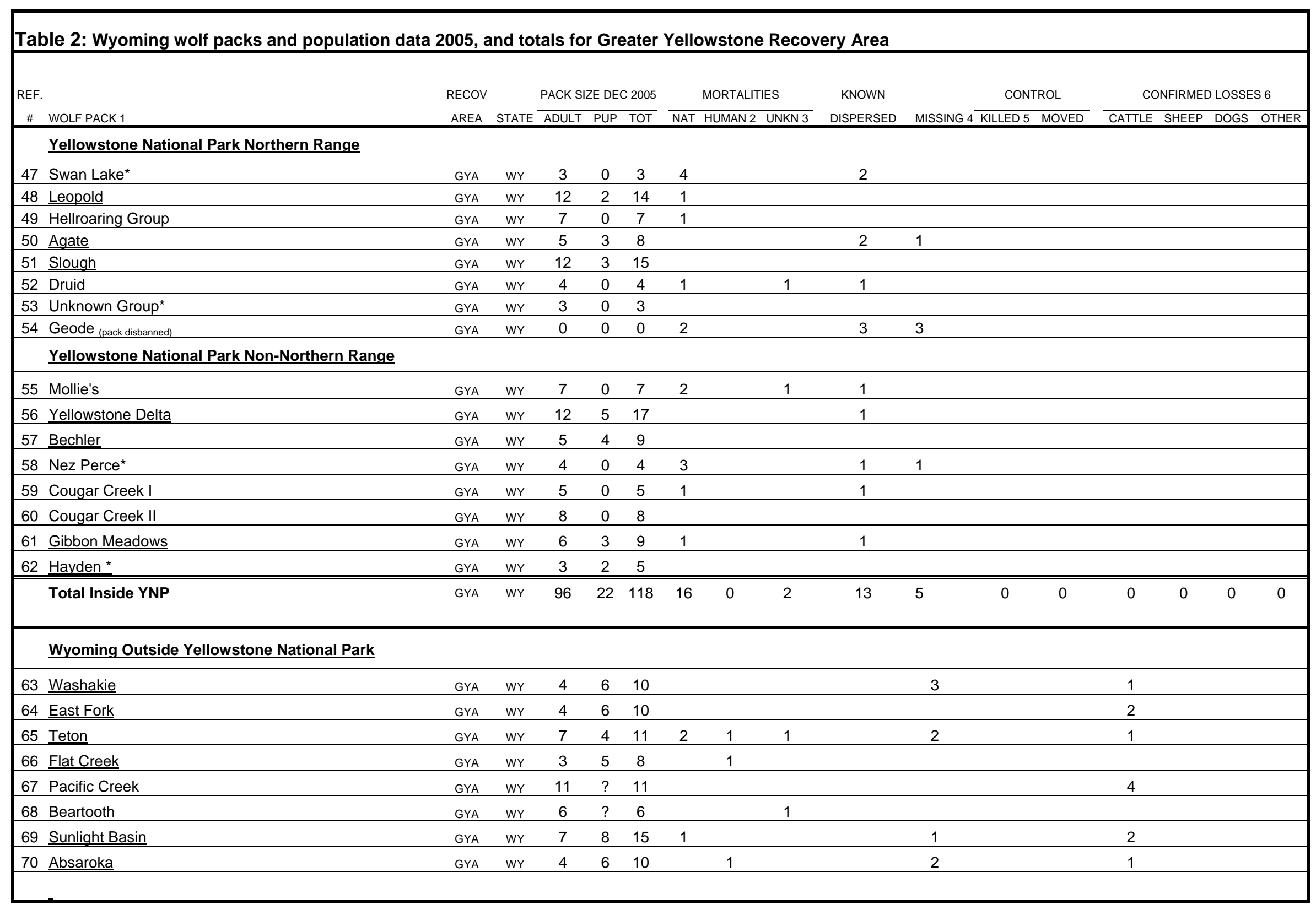




\begin{tabular}{|c|c|c|c|c|c|c|c|c|c|c|c|c|c|c|c|c|}
\hline \multirow{2}{*}{$\begin{array}{l}\text { REF. } \\
\text { \# WOLF PACK } 1\end{array}$} & \multirow{2}{*}{$\begin{array}{l}\text { RECOV } \\
\text { AREA }\end{array}$} & \multirow{2}{*}{ STATE } & \multicolumn{3}{|c|}{ PACK SIZE DEC 2005} & \multicolumn{3}{|c|}{ MORTALITIES } & \multirow{2}{*}{$\begin{array}{c}\text { KNOWN } \\
\text { DISPERSED }\end{array}$} & \multirow[b]{2}{*}{ MISSING 4} & \multicolumn{2}{|c|}{ CONTROL } & \multicolumn{4}{|c|}{ CONFIRMED LOSSES 6} \\
\hline & & & ADULT & PUP & TOT & NAT & HUMAN 2 & UNKN 3 & & & KILLED 5 & MOVED & CATTLE & SHEEP & DOGS & OTHER \\
\hline 71 South Fork & GYA & WY & 4 & 5 & 9 & & & & & & & & 3 & & & \\
\hline 72 Wood River & GYA & WY & 2 & 3 & 5 & & & & & & & & 1 & & & \\
\hline 73 Greybull River & GYA & WY & 6 & $?$ & 6 & & & & & & 2 & & 6 & & & \\
\hline 74 Carter Mtn. & GYA & WY & 2 & 4 & 6 & & & & & & 6 & & 6 & & & \\
\hline 75 Driggs/Teton & GYA & WY & 5 & 0 & 5 & & & & & & & & & & & \\
\hline Misc. outside YNP & GYA & WY & 22 & $?$ & 22 & 1 & & 3 & & & 33 & & 27 & 27 & 1 & \\
\hline Total outside YNP & GYA & WY & 87 & 47 & 134 & 4 & 3 & 5 & 0 & 8 & 41 & 0 & 54 & 27 & 1 & 0 \\
\hline Total Wyoming in GYA & GYA & WY & 183 & 69 & 252 & 20 & 3 & 7 & 13 & 13 & 41 & 0 & 54 & 27 & 1 & 0 \\
\hline WY part of GYA (Table 2) & GYA & WY & 183 & 69 & 252 & 20 & 3 & 7 & 13 & 13 & 41 & 0 & 54 & 27 & 1 & 0 \\
\hline MT part of GYA (Table 1b) & GYA & MT & $42+$ & $15+$ & 66 & 5 & 5 & 1 & 2 & 3 & 19 & 0 & 7 & 26 & 1 & 0 \\
\hline ID part of GYA (Table 3) & GYA & ID & 5 & 2 & 7 & 0 & 1 & 0 & 0 & 0 & 0 & 0 & 0 & 0 & 0 & 0 \\
\hline GYA TOTAL & & & 230 & 86 & 325 & 25 & 9 & 8 & 15 & 16 & 60 & 0 & 61 & 53 & 2 & 0 \\
\hline
\end{tabular}

1 Underlined packs are counted as breeding pairs toward recovery goals.

2 Excludes wolves killed in control actions.

3 Does not include pups that disappeared before winter.

4 Collared wolves that ceased transmitting in 2005.

5 Includes agency lethal control.

6 Includes only domestic animals confirmed killed by wolves.

* No collars; numerous reliable, verified reports.

file: FINAL 2005 WY and YNP Table 2 2-19-06 


\begin{tabular}{|c|c|c|c|c|c|c|c|c|c|c|c|c|c|c|c|c|}
\hline \multirow{2}{*}{$\begin{array}{c}\text { REF } \\
\text { \# }\end{array}$} & \multirow{2}{*}{ WOLF PACK 1} & \multirow{2}{*}{$\begin{array}{l}\text { RECOV } \\
\text { AREA }\end{array}$} & \multirow[b]{2}{*}{ STATE } & \multicolumn{3}{|c|}{$\begin{array}{l}\text { MINIMUM ESTIMATED } \\
\text { PACK SIZE DEC } 2005 \\
\end{array}$} & \multicolumn{3}{|c|}{$\begin{array}{c}\text { DOCUMENTED AND SUSPECTED } \\
\text { MORTALITIES }\end{array}$} & \multirow{2}{*}{$\begin{array}{l}\text { KNOWN } \\
\text { DISPERSED } \\
\end{array}$} & \multirow[b]{2}{*}{ MISSING 4} & \multicolumn{2}{|c|}{ CONTROL } & \multicolumn{3}{|c|}{ CONFIRMED LOSSES 6} \\
\hline & & & & ADULT & PUP & TOT & NATURAL & HUMAN 2 & UNKN 3 & & & KILLED 5 & MOVED & CATTLE & SHEEP & DOGS OTHER \\
\hline 76 & Avery & $\mathrm{CID}$ & ID & 2 & 2 & 4 & & & & & & & & & & \\
\hline 77 & Bear Valley & CID & ID & 5 & 3 & 8 & & & & & & & & & & \\
\hline 78 & Bimerick Meadow & $\mathrm{CID}$ & ID & 2 & 2 & 4 & & & & & & & & & & \\
\hline 79 & Blue Bunch & $\mathrm{CID}$ & ID & 2 & 4 & 6 & & & & & & & & & 37 & \\
\hline 80 & Buffalo Ridge & $\mathrm{CID}$ & ID & 3 & 6 & 9 & & & & & 1 & 1 & & 2 & & \\
\hline 81 & Calderwood & $\mathrm{CID}$ & ID & 4 & $?$ & 4 & & & & & & & & & & \\
\hline 82 & Carey Dome & $\mathrm{CID}$ & ID & $1+$ & $?$ & 9 & & & & & & & & & 4 & \\
\hline 83 & Castle Peak/East Pass & $\mathrm{CID}$ & ID & $?$ & $?$ & $?$ & & 1 & & & & & & & 25 & 1 \\
\hline 84 & Chamberlain Basin & $\mathrm{CID}$ & ID & $?$ & $?$ & 6 & & & & & & & & & & \\
\hline 85 & Chesimia & $\mathrm{CID}$ & ID & 3 & 2 & 5 & & & & & & 4 & & 4 & & 5 \\
\hline 86 & Cold Springs & $\mathrm{CID}$ & ID & $?$ & $?$ & 3 & & 1 & & & & & & & & \\
\hline & Coolwater Ridge & $\mathrm{CID}$ & ID & 7 & 4 & 11 & & & & & & & & & & 1 \\
\hline 88 & Copper Basin & $\mathrm{CID}$ & ID & 2 & 2 & 4 & & & & & & 9 & & 8 & & \\
\hline & Eagle Mountain & $\mathrm{CID}$ & ID & 2 & 4 & 6 & & & & & & & & & & \\
\hline & Earthquake Basin & $\mathrm{CID}$ & ID & 2 & 6 & 8 & & & & & & & & & & \\
\hline & Eldorado & $\mathrm{CID}$ & ID & 3 & 2 & 5 & & & & & & & & & & \\
\hline & Fishhook & $\mathrm{CID}$ & ID & 2 & $2+$ & 5 & & & & & & & & & & \\
\hline 93 & Five Lakes Butte & $\mathrm{CID}$ & ID & 3 & 2 & 5 & & & & & & & & & & \\
\hline & Florence & $\mathrm{CID}$ & ID & 9 & 6 & 15 & & & & & & & & 1 & & \\
\hline 95 & Galena & $\mathrm{CID}$ & ID & 8 & 3 & 11 & & & & 1 & & & & & 7 & \\
\hline & Gold Fork & $\mathrm{CID}$ & ID & 2 & 2 & 4 & & & & & & & & & & \\
\hline & Golden Creek & $\mathrm{CID}$ & ID & 5 & 2 & 7 & & $3^{a}$ & & 2 & & & & & & \\
\hline 98 & Gospel Hump & $\mathrm{CID}$ & ID & $?$ & $?$ & $?$ & & & & & & & & & & \\
\hline 99 & Hazard Lake & $\mathrm{CID}$ & ID & $?$ & $?$ & $3 ?$ & & & & & & & & & 7 & \\
\hline
\end{tabular}




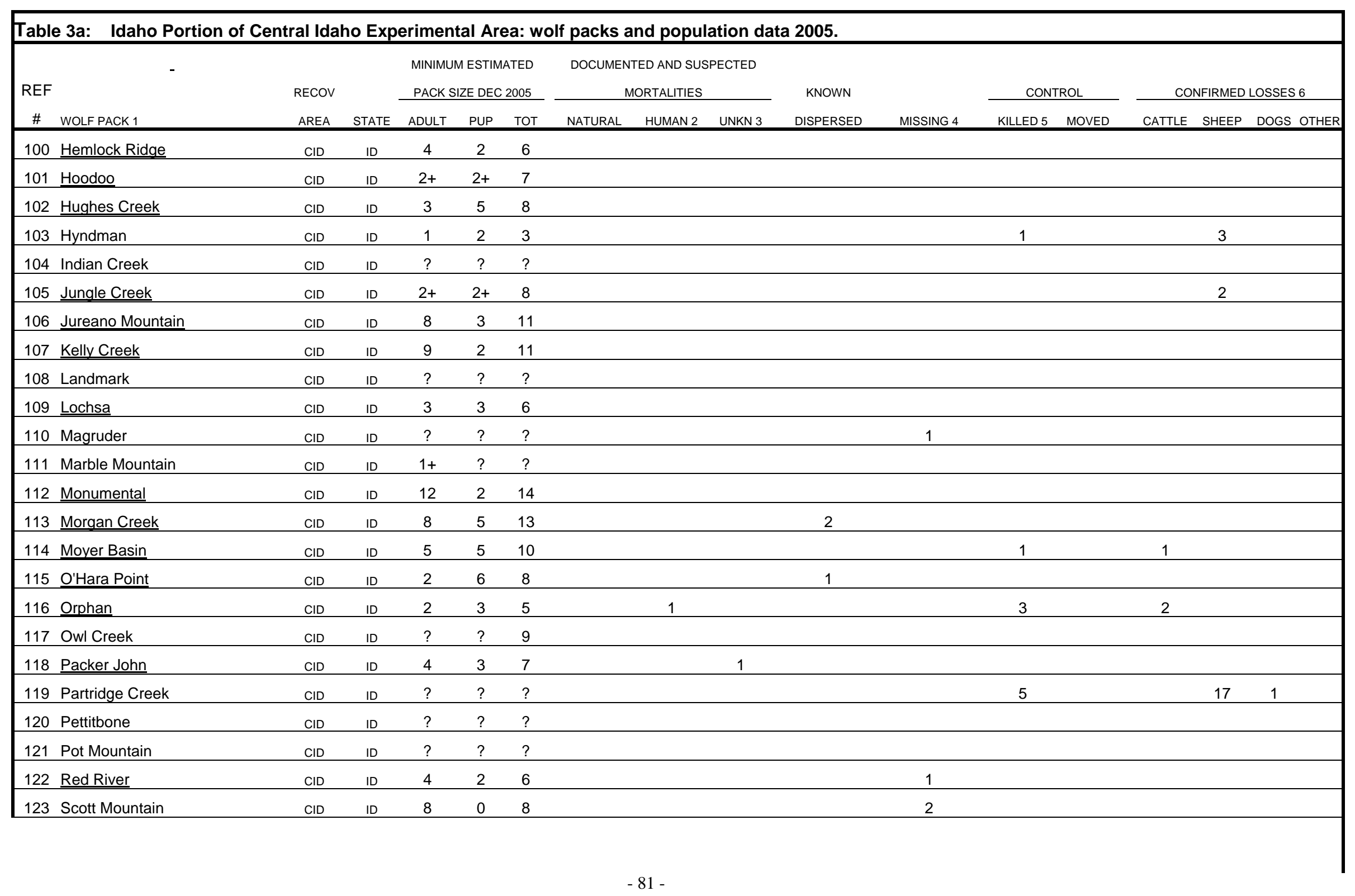




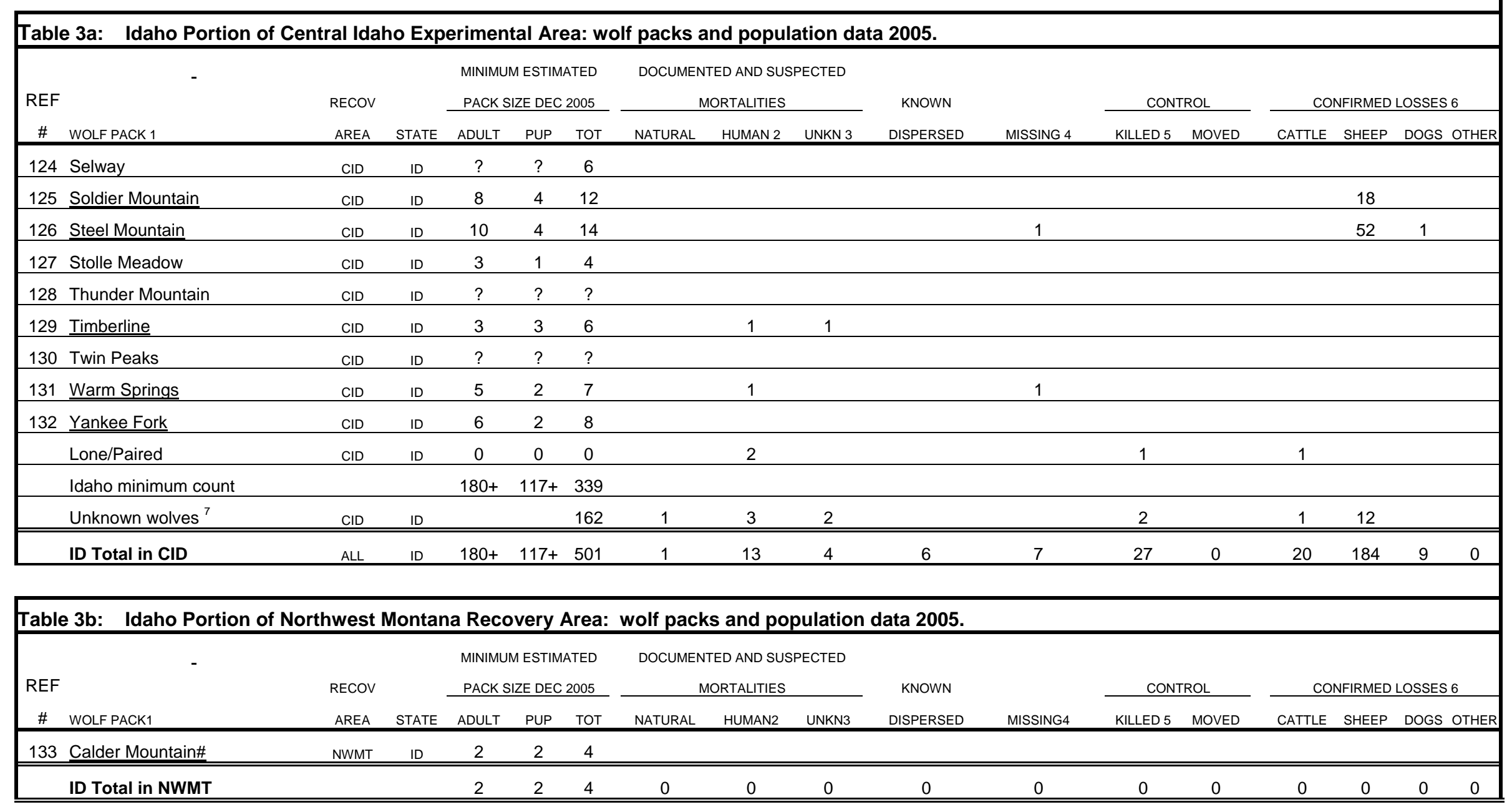




\begin{tabular}{|c|c|c|c|c|c|c|c|c|c|c|c|c|c|c|c|c|c|}
\hline \multirow{2}{*}{$\begin{array}{c}\text { REF } \\
\# \\
\end{array}$} & \multirow{2}{*}{ WOLF PACK1 } & \multirow{2}{*}{$\begin{array}{l}\text { RECOV } \\
\text { AREA } \\
\end{array}$} & \multirow[b]{2}{*}{ STATE } & \multicolumn{3}{|c|}{$\begin{array}{l}\text { MINIMUM ESTIMATED } \\
\text { PACK SIZE DEC } 2005\end{array}$} & \multicolumn{3}{|c|}{$\begin{array}{c}\text { DOCUMENTED AND SUSPECTED } \\
\text { MORTALITIES } \\
\end{array}$} & \multirow{2}{*}{$\begin{array}{c}\text { KNOWN } \\
\text { DISPERSED } \\
\end{array}$} & \multirow[b]{2}{*}{ MISSING4 } & \multicolumn{2}{|c|}{ CONTROL } & \multicolumn{4}{|c|}{ CONFIRMED LOSSES 6} \\
\hline & & & & ADULT & PUP & TOT & NATURAL & HUMAN2 & UNKN3 & & & KILLED 5 & MOVED & CATTLE & SHEEP & DOGS & OTHER \\
\hline \multirow[t]{2}{*}{134} & Biscuit Basi & GYA & $\mathrm{ID}$ & 5 & 2 & 7 & & 1 & & & & & & & & & \\
\hline & ID Total in & & & 5 & 2 & 7 & 0 & 1 & 0 & 0 & 0 & 0 & 0 & 0 & 0 & 0 & 0 \\
\hline & ID STATE T & ALL & ID & $187+$ & $121+$ & 512 & 1 & 14 & 4 & 6 & 7 & 27 & 0 & 20 & 184 & 9 & 0 \\
\hline
\end{tabular}

\begin{tabular}{|c|c|c|c|c|c|c|c|c|c|c|c|c|c|c|c|c|}
\hline MT in CID (Table 1c) & CID & MT & $20+$ & $17+$ & 64 & 0 & 1 & 1 & 0 & 0 & 14 & 0 & 7 & 6 & 0 & 2 \\
\hline ID in CID (Table 3a) & ALL & ID & $180+$ & $117+$ & 501 & 1 & 13 & 4 & 6 & 7 & 27 & 0 & 20 & 184 & 9 & 0 \\
\hline CID TOTAL & $\mathrm{CID}$ & ID/MT & $200+$ & $134+$ & 565 & 1 & 14 & 5 & 6 & 7 & 41 & 0 & 27 & 190 & 9 & 2 \\
\hline
\end{tabular}

1 Underlined packs are counted as breeding pairs toward recovery goals.

2 Excludes wolves killed in control actions.

3 Does not include pups that disappeared before winter.

4 Collared wolves that became missing in 2005.

5 Includes agency lethal control and take by private citizens under 10j regulation.

6 Includes only domestic animals confirmed killed by wolves.

7 See narrative text for explanation.

a Two wolves killed while dispersing. 
Table 4a: Northern Rocky Mountain minimum fall wolf population and breeding pairs* $1979-2005$, by Federal Recovery Area

\section{Minimum fall wolf population by recovery area:}

\begin{tabular}{|c|c|c|c|c|c|c|c|c|c|c|c|c|c|c|c|c|c|c|c|c|c|c|c|c|c|c|c|}
\hline Year & 79 & 80 & 81 & 82 & 83 & 84 & 85 & 86 & 87 & 88 & 89 & 90 & 91 & 92 & 93 & 94 & 95 & 96 & 97 & 98 & 99 & 00 & 01 & 02 & 03 & 04 & 05 \\
\hline \multicolumn{28}{|c|}{ Recovery Area } \\
\hline NWMT & 2 & 1 & 2 & 8 & 6 & 6 & 13 & 15 & 10 & 14 & 12 & 33 & 29 & 41 & 55 & 48 & 66 & 70 & 56 & 49 & 63 & 64 & 84 & 108 & 92 & 59 & 130 \\
\hline GYA & & & & & & & & & & & & & & & & & 21 & 40 & 86 & 112 & 118 & 177 & 218 & 271 & 301 & 335 & 325 \\
\hline CID & & & & & & & & & & & & & & & & & 14 & 42 & 71 & 114 & 156 & 196 & 261 & 284 & 368 & 452 & 565 \\
\hline TOTAL & 2 & 1 & 2 & 8 & 6 & 6 & 13 & 15 & 10 & 14 & 12 & 33 & 29 & 41 & 55 & 48 & 101 & 152 & 213 & 275 & 337 & 437 & 563 & 663 & 761 & 846 & 1020 \\
\hline
\end{tabular}

Breeding pairs by recovery area:

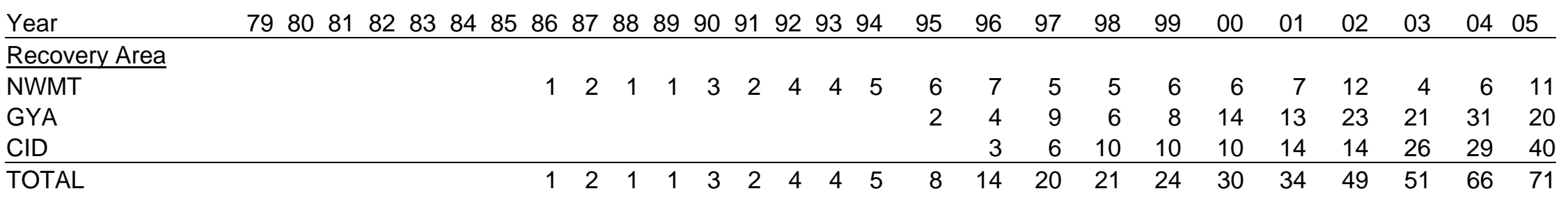

\footnotetext{
* By the standards of the Rocky Mountain Gray Wolf Recovery Plan and wolf reintroduction environmental impact statement, a breeding pair is defined as an adult male and an adult female wolf, accompanied by 2 pups that survived at least until Dec 31 . Recovery goals call for 10 breeding pairs per area, or a total of 30 breeding pairs distributed through the 3 areas, for 3 years.

NOTE: $\quad$ Each year, wolf packs discovered in the current year that contain $\geq 2$ yearlings and $\geq 2$ adults are added to the previous year's breeding pair and population totals; similarly, if evidence in the current year indicates that $<2$ pups or $<2$ adults survived on December 31 of the previous year, that wolf pack is deleted from the previous year's breeding pair counts and population totals. Therefore, breeding pair counts and population totals are updated in current annual reports.
} 
Table 4b: Northern Rocky Mountain minimum fall wolf population and breeding pairs* 1979-2005, by State

\section{Minimum fall wolf population by state:}

\begin{tabular}{|c|c|c|c|c|c|c|c|c|c|c|c|c|c|c|c|c|c|c|c|c|c|c|c|c|c|c|c|}
\hline Year & 79 & 80 & 81 & 82 & 83 & 84 & 85 & 86 & 87 & 88 & 89 & 90 & 91 & 92 & 93 & 94 & 95 & 96 & 97 & 98 & 99 & 00 & 01 & 02 & 03 & 04 & 05 \\
\hline State & & & & & & & & & & & & & & & & & & & & & & & & & & & \\
\hline MT & 2 & 1 & 2 & 8 & 6 & 6 & 13 & 15 & 10 & 14 & 12 & 33 & 29 & 41 & 55 & 48 & 66 & 70 & 56 & 49 & 74 & 97 & 123 & 183 & 182 & 152 & 256 \\
\hline WY & & & & & & & & & & & & & & & & & 21 & 40 & 86 & 112 & 107 & 153 & 189 & 217 & 234 & 272 & 252 \\
\hline ID & & & & & & & & & & & & & & & & & 14 & 42 & 71 & 114 & 156 & 187 & 251 & 263 & 345 & 422 & 512 \\
\hline TOTAL & 2 & 1 & 2 & 8 & 6 & 6 & 13 & 15 & 10 & 14 & 12 & 33 & 29 & 41 & 55 & 48 & 101 & 152 & 213 & 275 & 337 & 437 & 563 & 663 & 761 & 846 & 1020 \\
\hline
\end{tabular}

Breeding pairs by state:

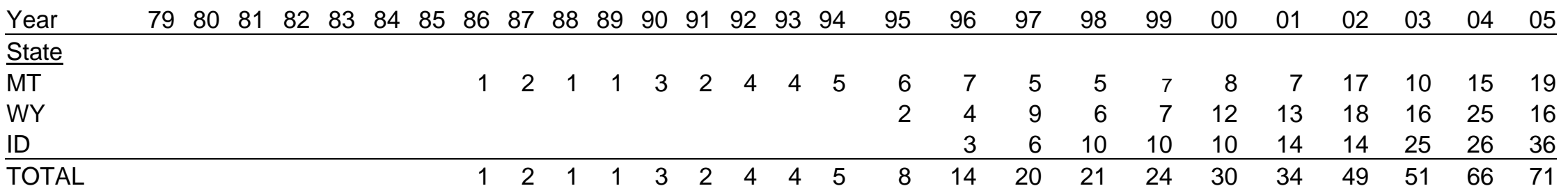

\footnotetext{
* By the standards of the Rocky Mountain Gray Wolf Recovery Plan and wolf reintroduction environmental impact statement, a breeding pair is defined as an adult male and an adult female wolf, accompanied by 2 pups that survived at least until Dec 31 . Recovery goals call for 10 breeding pairs per area, or a total of 30 breeding pairs distributed through the 3 areas, for 3 years.
}

NOTE: $\quad$ Each year, wolf packs discovered in the current year that contain $\geq 2$ yearlings and $\geq 2$ adults are added to the previous year's breeding pair and population totals; similarly, if evidence in the current year indicates that $<2$ pups or $<2$ adults survived on December 31 of the previous year, that wolf pack is deleted from the previous year's breeding pair counts and population totals. Therefore, breeding pair counts and population totals are updated in current annual reports. 
Table 5a: Northern Rocky Mountain States confirmed wolf depredation1 and wolf management, 1987-2005 by recovery area.

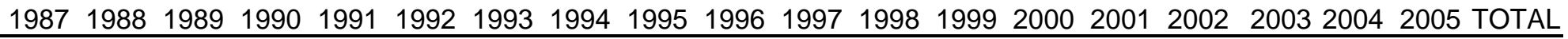

\begin{tabular}{|c|c|c|c|c|c|c|c|c|c|c|c|c|c|c|c|c|c|c|c|c|}
\hline \multicolumn{21}{|c|}{ Northwest Montana Recovery Area: } \\
\hline cattle & 6 & 0 & 3 & 5 & 2 & 1 & 0 & 6 & 3 & 9 & 16 & 9 & 13 & 10 & 8 & 9 & 6 & 6 & 9 & 121 \\
\hline sheep & 10 & 0 & 0 & 0 & 2 & 0 & 0 & 0 & 0 & 0 & 30 & 0 & 19 & 2 & 5 & 13 & 3 & 1 & 1 & 86 \\
\hline other 3 & 0 & 0 & 0 & 0 & 0 & 0 & 0 & 0 & 0 & 0 & 0 & 0 & 0 & 0 & 4 & 5 & 0 & 1 & 0 & 10 \\
\hline dogs & 0 & 0 & 0 & 1 & 0 & 0 & 0 & 0 & 3 & 1 & 0 & 0 & 2 & 3 & 1 & 4 & 0 & 0 & 0 & 15 \\
\hline wolves moved & 0 & 0 & 4 & 0 & 3 & 0 & 0 & 2 & 2 & 10 & 7 & 0 & 4 & 0 & 5 & 0 & 0 & 0 & 0 & 37 \\
\hline wolves killed & 4 & 0 & 1 & 1 & 0 & 0 & 0 & 0 & 0 & 4 & 14 & 4 & 9 & 4 & 3 & 9 & 14 & 1 & 2 & 70 \\
\hline \multicolumn{21}{|c|}{ Greater Yellowstone Recovery Area: } \\
\hline cattle & & & & & & & & & 0 & 0 & 5 & 3 & 4 & 7 & 22 & 33 & 45 & 100 & 61 & 280 \\
\hline sheep & & & & & & & & & 0 & 13 & 67 & 7 & 13 & 39 & 117 & 71 & 90 & 99 & 53 & 569 \\
\hline other 3 & & & & & & & & & 0 & 0 & 0 & 0 & 1 & 0 & 0 & 0 & 10 & 4 & 0 & 15 \\
\hline dogs & & & & & & & & & 1 & 0 & 0 & 4 & 7 & 8 & 4 & 1 & 0 & 6 & 2 & 33 \\
\hline wolves moved & & & & & & & & & 6 & 8 & 14 & 0 & 0 & 6 & 8 & 0 & 0 & 0 & 0 & 42 \\
\hline wolves killed & & & & & & & & & 0 & 1 & 6 & 3 & 9 & 6 & 9 & 23 & 38 & 55 & 61 & 211 \\
\hline \multicolumn{21}{|c|}{ Central Idaho Recovery Area: } \\
\hline cattle & & & & & & & & & 0 & 2 & 1 & 9 & 16 & 15 & 10 & 10 & 13 & 24 & 27 & 127 \\
\hline sheep & & & & & & & & & 0 & 24 & 29 & 5 & 57 & 39 & 16 & 15 & 118 & 170 & 190 & 663 \\
\hline other 3 & & & & & & & & & 0 & 0 & 0 & 0 & 0 & 0 & 0 & 0 & 0 & 0 & 2 & 2 \\
\hline dogs & & & & & & & & & 0 & 1 & 4 & 1 & 6 & 0 & 1 & 4 & 6 & 3 & 9 & 35 \\
\hline wolves moved & & & & & & & & & 0 & 5 & 0 & 3 & 15 & 10 & 5 & 0 & 0 & 0 & 0 & 38 \\
\hline wolves killed & & & & & & & & & 0 & 1 & 1 & 0 & 5 & 10 & 7 & 14 & 7 & 30 & 41 & 116 \\
\hline \multicolumn{21}{|c|}{ Total, 3 Recovery Areas: } \\
\hline cattle & 6 & 0 & 3 & 5 & 2 & 1 & 0 & 6 & 3 & 11 & 22 & 21 & 33 & 32 & 40 & 52 & 64 & 130 & 97 & 528 \\
\hline sheep & 10 & 0 & 0 & 0 & 2 & 0 & 0 & 0 & 0 & 37 & 126 & 12 & 89 & 80 & 138 & 99 & 211 & 270 & 244 & 1318 \\
\hline other 3 & 0 & 0 & 0 & 0 & 0 & 0 & 0 & 0 & 0 & 0 & 0 & 0 & 1 & 0 & 4 & 5 & 10 & 5 & 2 & 27 \\
\hline dogs & 0 & 0 & 0 & 1 & 0 & 0 & 0 & 0 & 4 & 2 & 4 & 5 & 15 & 11 & 6 & 9 & 6 & 9 & 11 & 83 \\
\hline wolves moved & 0 & 0 & 4 & 0 & 3 & 0 & 0 & 2 & 8 & 23 & 21 & 3 & 19 & 16 & 18 & 0 & 0 & 0 & 0 & 117 \\
\hline wolves killed2 & 4 & 0 & 1 & 1 & 0 & 0 & 0 & 0 & 0 & 6 & 21 & 7 & 23 & 20 & 19 & 46 & 59 & 86 & 103 & 396 \\
\hline
\end{tabular}

1 Numbers of animals confirmed killed by wolves in calendar year.

2 Includes wolves legally shot by ranchers. Others killed in government control efforts.

3 Total livestock other than cattle and sheep confirmed killed by wolves between 1987 and 2005 are 9 llamas, 12 goats and 6 horses.

-86 - 
Table 5b: Northern Rocky Mountain confirmed wolf depredation1 and wolf management, 1987-2005 (by state)

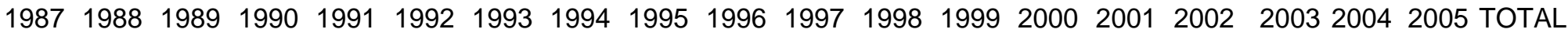

\begin{tabular}{|c|c|c|c|c|c|c|c|c|c|c|c|c|c|c|c|c|c|c|c|c|}
\hline \multicolumn{21}{|l|}{ Montana } \\
\hline cattle & 6 & 0 & 3 & 5 & 2 & 1 & 0 & 6 & 3 & 10 & 19 & 10 & 20 & 14 & 12 & 20 & 24 & 36 & 23 & 214 \\
\hline sheep & 10 & 0 & 0 & 0 & 2 & 0 & 0 & 0 & 0 & 13 & 41 & 0 & 25 & 7 & 50 & 84 & 86 & 92 & 33 & 443 \\
\hline other 3 & 0 & 0 & 0 & 0 & 0 & 0 & 0 & 0 & 0 & 0 & 0 & 0 & 0 & 0 & 4 & 5 & 0 & 3 & 2 & 14 \\
\hline dogs & 0 & 0 & 0 & 1 & 0 & 0 & 0 & 0 & 4 & 1 & 0 & 1 & 2 & 5 & 2 & 5 & 1 & 4 & 1 & 27 \\
\hline wolves moved & 0 & 0 & 4 & 0 & 3 & 0 & 0 & 2 & 8 & 22 & 20 & 0 & 14 & 6 & 17 & 0 & 0 & 0 & 0 & 96 \\
\hline wolves killed & 4 & 0 & 1 & 1 & 0 & 0 & 0 & 0 & 0 & 5 & 18 & 4 & 19 & 7 & 8 & 26 & 34 & 40 & 35 & 202 \\
\hline \multicolumn{21}{|l|}{ Wyoming } \\
\hline cattle & & & & & & & & & 0 & 0 & 2 & 2 & 2 & 3 & 18 & 23 & 34 & 75 & 54 & 213 \\
\hline sheep & & & & & & & & & 0 & 0 & 56 & 7 & 0 & 25 & 34 & 0 & 7 & 17 & 27 & 173 \\
\hline other 3 & & & & & & & & & 0 & 0 & 0 & 0 & 1 & 0 & 0 & 0 & 10 & 2 & 0 & 13 \\
\hline dogs & & & & & & & & & 0 & 0 & 0 & 3 & 6 & 6 & 2 & 0 & 0 & 2 & 1 & 20 \\
\hline wolves moved & & & & & & & & & 0 & 0 & 1 & 0 & 0 & 0 & 0 & 0 & 0 & 0 & 0 & 1 \\
\hline wolves killed & & & & & & & & & 0 & 0 & 2 & 3 & 1 & 2 & 4 & 6 & 18 & 29 & 41 & 106 \\
\hline \multicolumn{21}{|l|}{ Idaho } \\
\hline cattle & & & & & & & & & 0 & 1 & 1 & 9 & 11 & 15 & 10 & 9 & 6 & 19 & 20 & 101 \\
\hline sheep & & & & & & & & & 0 & 24 & 29 & 5 & 64 & 48 & 54 & 15 & 118 & 161 & 184 & 702 \\
\hline other 3 & & & & & & & & & 0 & 0 & 0 & 0 & 0 & 0 & 0 & 0 & 0 & 0 & 0 & 0 \\
\hline dogs & & & & & & & & & 0 & 1 & 4 & 1 & 7 & 0 & 2 & 4 & 5 & 3 & 9 & 36 \\
\hline wolves moved & & & & & & & & & 0 & 1 & 0 & 3 & 5 & 10 & 1 & 0 & 0 & 0 & 0 & 20 \\
\hline wolves killed & & & & & & & & & 0 & 1 & 1 & 0 & 3 & 11 & 7 & 14 & 7 & 17 & 27 & 88 \\
\hline \multicolumn{21}{|l|}{ Total, 3 States } \\
\hline$\overline{\text { cattle }}$ & 6 & 0 & 3 & 5 & 2 & 1 & 0 & 6 & 3 & 11 & 22 & 21 & 33 & 32 & 40 & 52 & 64 & 130 & 97 & 528 \\
\hline sheep & 10 & 0 & 0 & 0 & 2 & 0 & 0 & 0 & 0 & 37 & 126 & 12 & 89 & 80 & 138 & 99 & 211 & 270 & 244 & 1318 \\
\hline other 3 & 0 & 0 & 0 & 0 & 0 & 0 & 0 & 0 & 0 & 0 & 0 & 0 & 1 & 0 & 4 & 5 & 10 & 5 & 2 & 27 \\
\hline dogs & 0 & 0 & 0 & 1 & 0 & 0 & 0 & 0 & 4 & 2 & 4 & 5 & 15 & 11 & 6 & 9 & 6 & 9 & 11 & 83 \\
\hline wolves moved & 0 & 0 & 4 & 0 & 3 & 0 & 0 & 2 & 8 & 23 & 21 & 3 & 19 & 16 & 18 & 0 & 0 & 0 & 0 & 117 \\
\hline wolves killed2 & 4 & 0 & 1 & 1 & 0 & 0 & 0 & 0 & 0 & 6 & 21 & 7 & 23 & 20 & 19 & 46 & 59 & 86 & 103 & 396 \\
\hline
\end{tabular}

1 Numbers of animals confirmed killed by wolves in calendar year.

2 Includes wolves legally shot by ranchers. Others killed in government control efforts.

3 Total livestock other than cattle and sheep confirmed killed by wolves between 1987 and 2005 are 9 llamas, 12 goats and 6 horses. 


\section{APPENDIX 4}

\section{NORTHERN ROCKIES WOLF PACK DISTRIBUTION MAPS}

Figure 1. Central Idaho, Northwest Montana and Greater

Yellowstone wolf recovery areas (Key: Tables 1 - 3) ...................90

Figure 2. Northwest Montana wolf recovery area (Key: Table

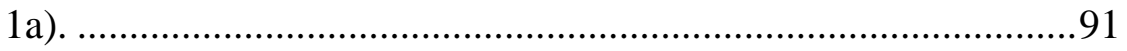

Figure 3. Greater Yellowstone Wolf recovery area (Key: Tables

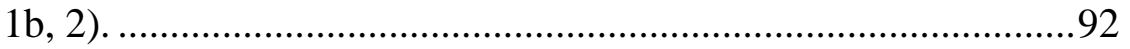

Figure 4. Central Idaho Wolf recovery area (Key: Tables 1b, 3)..................93 
Figure 1. Central Idaho, Northwest Montana and Greater Yellowstone Wolf Recovery Areas

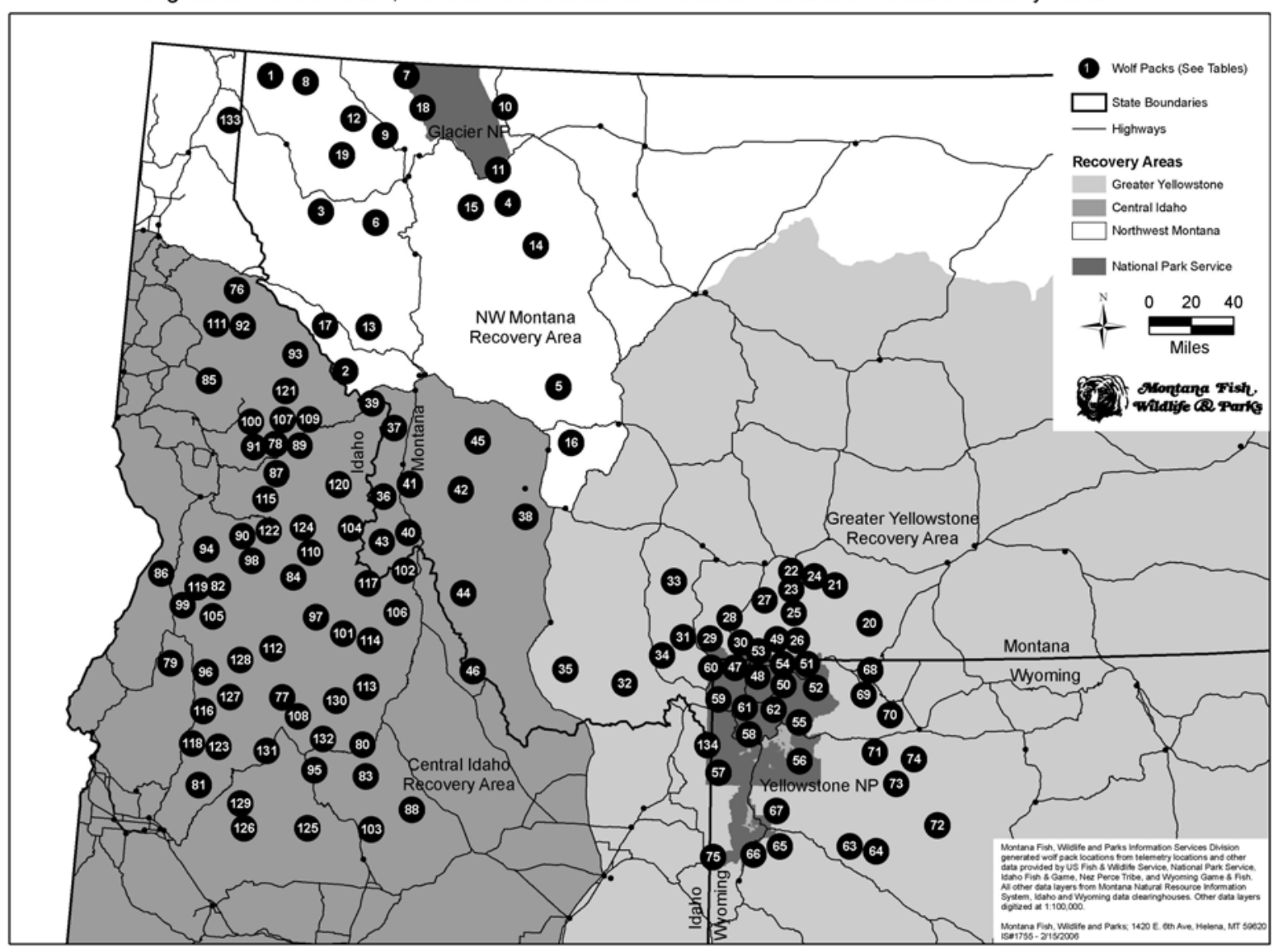


Figure 2. Northwest Montana Wolf Recovery Area

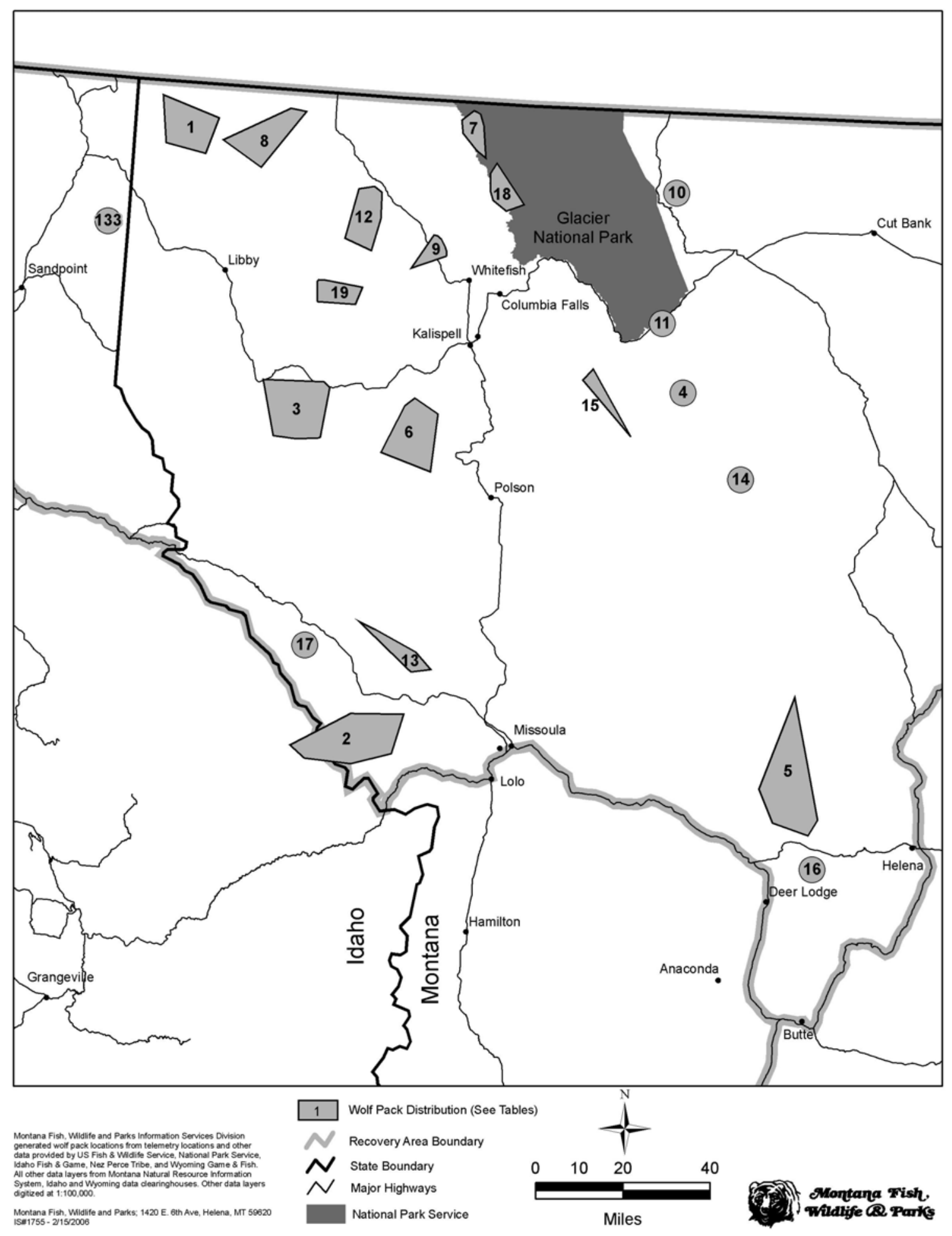


Figure 3. Greater Yellowstone Wolf Recovery Area

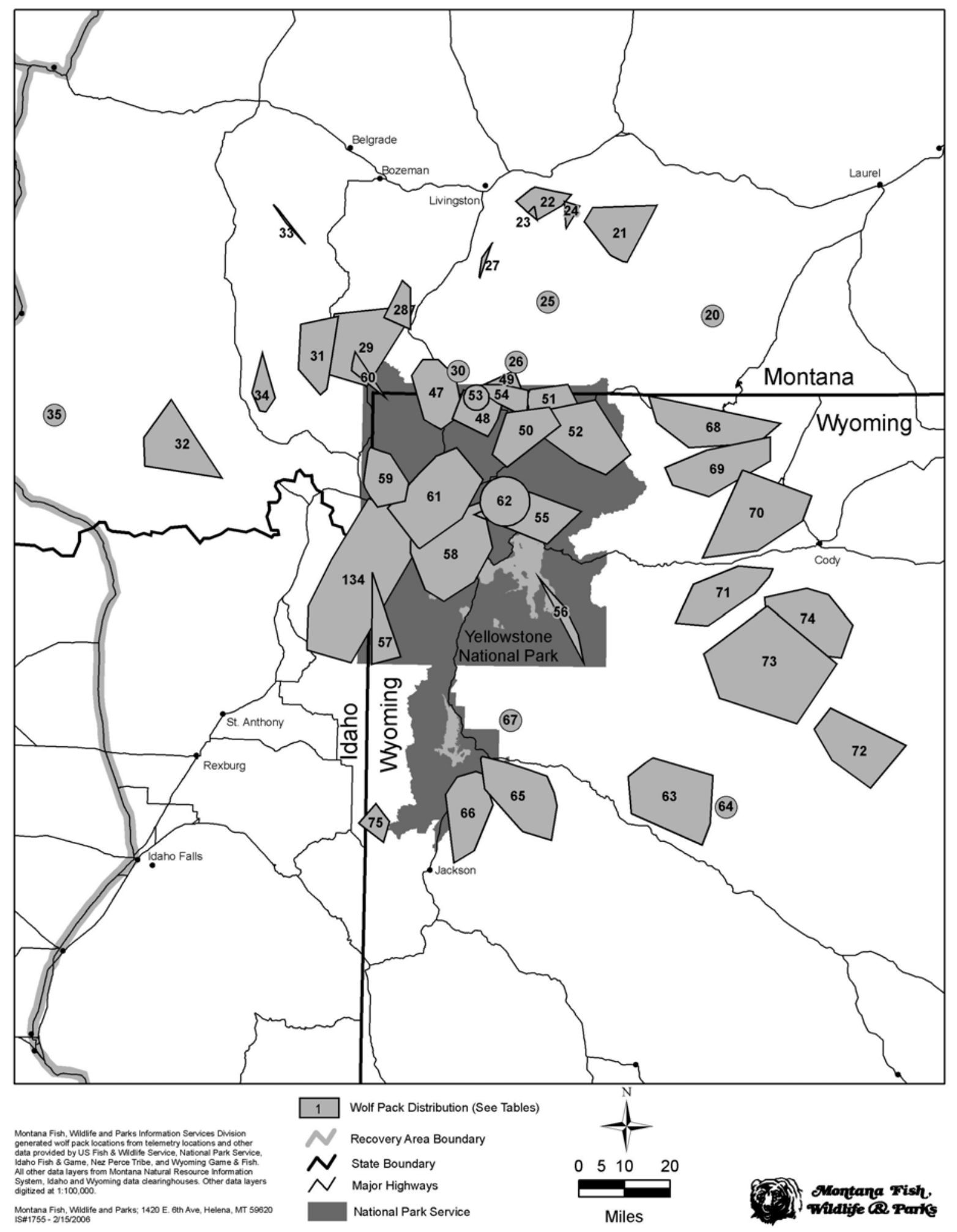


Figure 4. Central Idaho Wolf Recovery Area

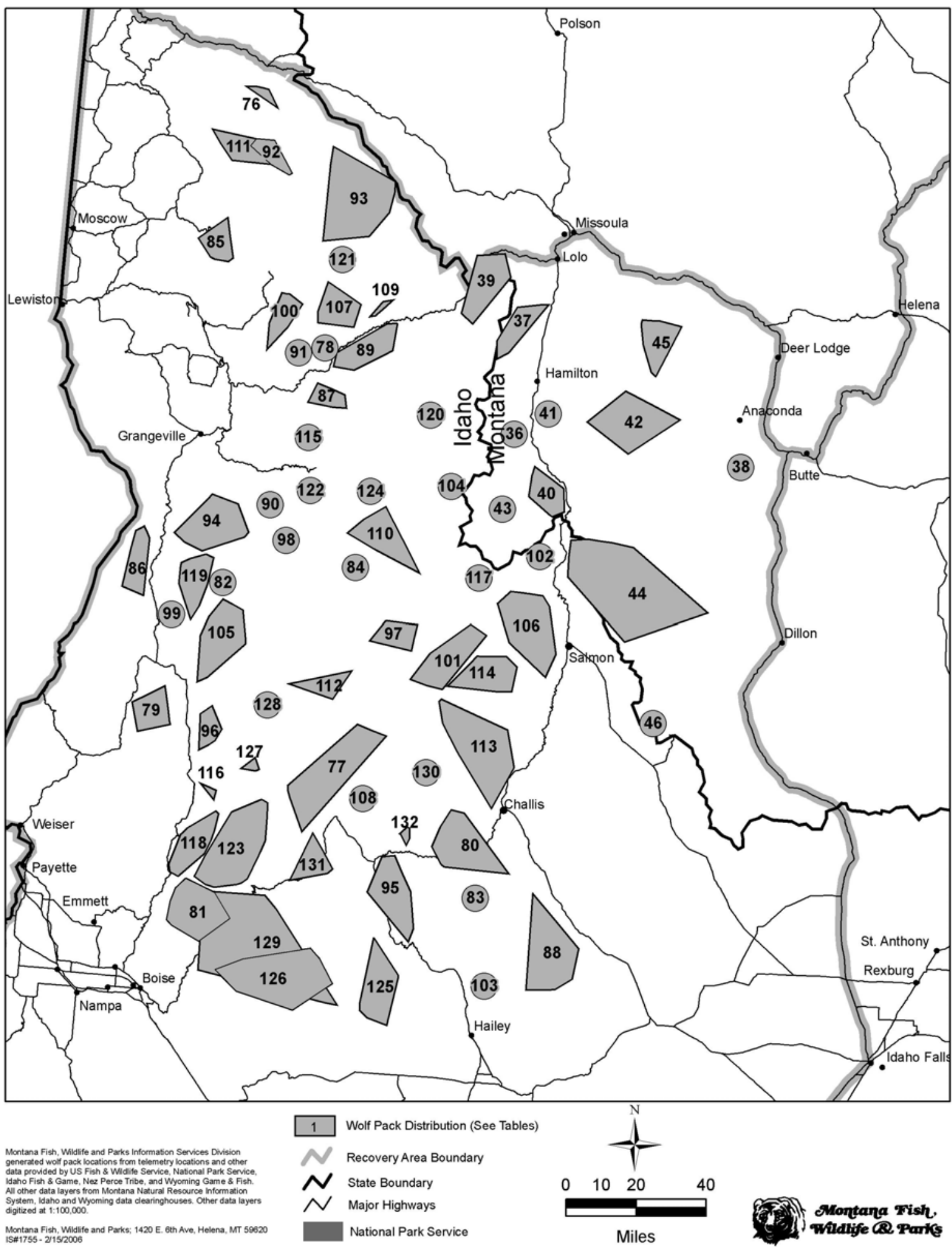




\section{APPENDIX 5}

\section{NORTHERN ROCKIES WOLF POPULATION GRAPHS}

Figure 5. Northern Rocky Mountain wolf population trends

1979-2005, by recovery area..

Figure 6. Northern Rocky Mountain wolf population trends

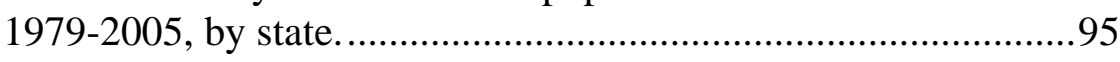



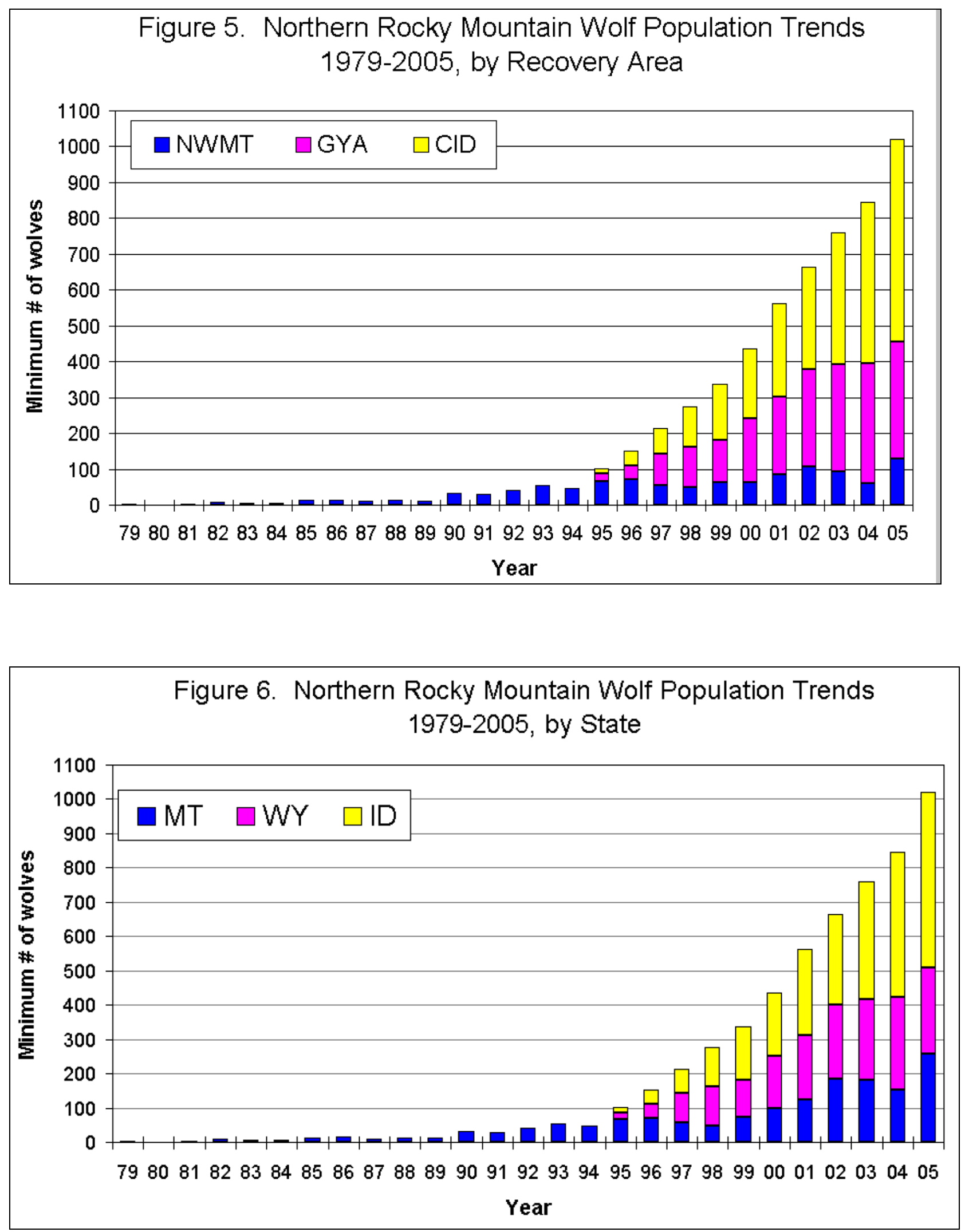